Supporting Information for:

\title{
PN-Containing Pyrene Derivatives: Synthesis, Structure and Photophysical Properties
}

Chun-Lin Deng, ${ }^{\dagger}$ Jeremy P. Bard, ${ }^{\dagger}$ Lev N. Zakharov, ${ }^{\dagger}$ Darren W. Johnson* ${ }^{*} \&$ \& Michael M. Haley,$\dagger$

Department of Chemistry \& Biochemistry and the Materials Science Institute, University of Oregon, Eugene, Oregon 97403-1253, United States

CAMCOR, University of Oregon, Eugene, Oregon 97403-1433, United States

1. Synthesis

2. X-ray Structure Data and Molecular Packing

3. Photophysical Properties

4. Electrochemistry

5. Theoretical Calculations

6. References

7. Copies of NMR Spectra for New Compounds 


\section{Synthesis}

General. NMR spectra were obtained on a Varian Inova $500 \mathrm{MHz}\left({ }^{1} \mathrm{H}: 500.11 \mathrm{MHz},{ }^{13} \mathrm{C}\right.$ 125.76 MHz, $\left.{ }^{19} \mathrm{~F} 470.53 \mathrm{MHz},{ }^{31} \mathrm{P} 202.46 \mathrm{MHz}\right)$ or an Bruker Avance-III-HD $600 \mathrm{MHz}\left({ }^{1} \mathrm{H}\right.$ : $\left.599.98 \mathrm{MHz},{ }^{13} \mathrm{C}: 150.87 \mathrm{MHz}\right)$ spectrometer. Chemical shifts $(\delta)$ are expressed in ppm using residual non-deuterated solvent present in the bulk deuterated solvent $\left(\mathrm{CDCl}_{3}:{ }^{1} \mathrm{H} 7.26 \mathrm{ppm},{ }^{13} \mathrm{C}\right.$ 77.16 ppm; DMSO- $\left.d_{6}:{ }^{1} \mathrm{H} 2.50 \mathrm{ppm},{ }^{13} \mathrm{C} 39.52 \mathrm{ppm}\right) .{ }^{19} \mathrm{~F}$ chemical shifts are reported against $\mathrm{CFCl}_{3}$ external standard $(\delta 0 \mathrm{ppm}) .{ }^{31} \mathrm{P}$ chemical shifts are reported against $85 \% \mathrm{H}_{3} \mathrm{PO}_{4}(\delta 0 \mathrm{ppm})$ as external reference. Mass spectra data were acquired on a Waters SYNAPT QToF in positive ion mode with a Shimadzu LC20AD HPLC front end. The solvents were MeCN: $\mathrm{H}_{2} \mathrm{O}: 0.1 \%$ $\mathrm{HCO}_{2} \mathrm{H}$ at a flow rate of $0.05 \mathrm{~mL} \mathrm{~min}^{-1}$ with a $5 \mu \mathrm{L}$ injection on a loop injection. Preparative SEC was performed using a JAI Recycling Preparative HPLC (Model LC-9101) with a JAIGEL-1H preparative column with $\mathrm{CHCl}_{3}$ as solvent. Analytical TLC was carried out on TLC plates $(5 \times 10$ $\mathrm{cm}$ with $0.25 \mathrm{~mm}$ thickness, silica gel $60 \mathrm{~F}_{254}$, Merck, Darmstadt, Germany) cut from the commercially available aluminium sheets. Solvents and reagents were used as purchased from suppliers, unless anhydrous conditions were employed, in which case, solvents were freshly distilled from sodium/benzophenone under $\mathrm{N}_{2}$ atmosphere (THF) or as purchased. 1Hydroxypyrene (s1), ${ }^{1} \quad$ 2,3,5,6-tetrabromo-4-ethyl-4-nitro-2,5-cyclohexadien-1-one (s2), ${ }^{2} \quad 3,5$ bis(trifluoromethyl)phenylethyne ${ }^{3}$ and phenyldiphenoxyphosphine $\left[\mathrm{PPh}(\mathrm{OPh})_{2}\right]^{4}$ were synthesized by their reported procedures.

Scheme S1 Synthesis of 1 and 2

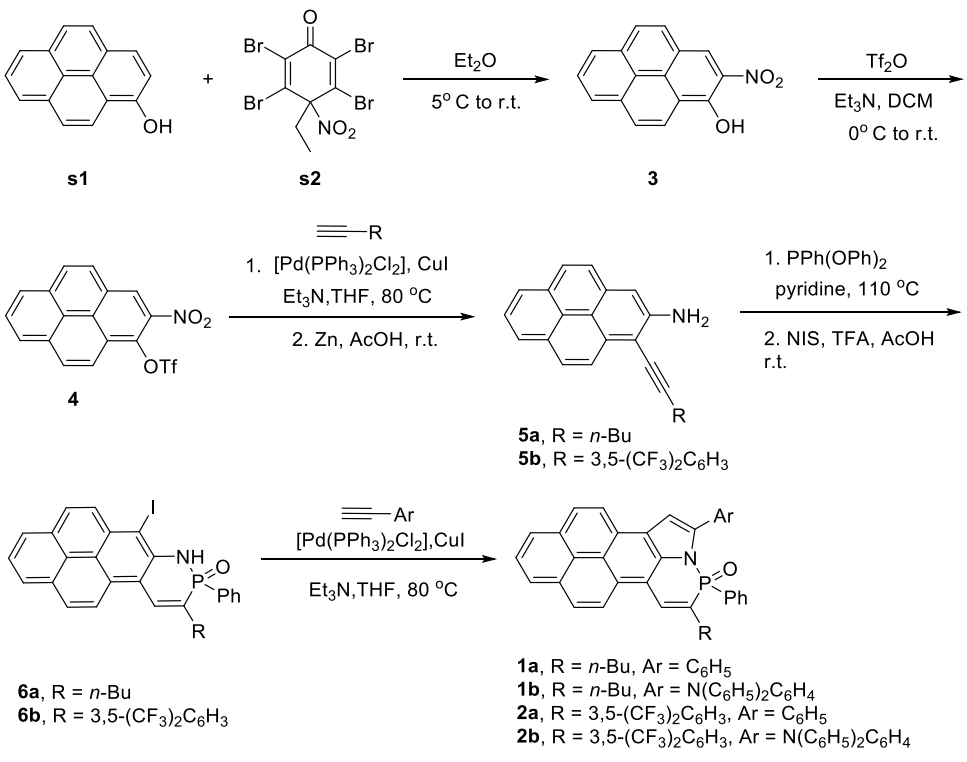


1-Hydroxy-2-nitropyrene (3). To a solution of 1-hydroxypyrene (s1, $277 \mathrm{mg}, 1.27 \mathrm{mmol}$ ) in $\mathrm{Et}_{2} \mathrm{O}(150 \mathrm{~mL})$ cooled to $5^{\circ} \mathrm{C}$ was added reagent $\mathbf{s} 2(627 \mathrm{mg}, 1.3 \mathrm{mmol})$ in small portions over 5 $\min$. The reaction mixture was stirred for $1 \mathrm{~h}$ at room temperature while following the reaction by TLC. The mixture was filtered, and the collected solid was dried under the vacuum to provide 3 (270 mg, 83\%) as a brown-orange solid. $R_{\mathrm{f}}=0.67$ (hexane). ${ }^{1} \mathrm{H} \mathrm{NMR}\left(500 \mathrm{MHz}, \mathrm{CDCl}_{3}\right) \delta 8.78$ (s, 1H), 8.38-8.33 (m, 4H), $8.25(\mathrm{~d}, J=8.9 \mathrm{~Hz}, 1 \mathrm{H}), 8.21(\mathrm{t}, J=7.7 \mathrm{~Hz}, 1 \mathrm{H}), 8.11(\mathrm{~d}, J=8.9 \mathrm{~Hz}$, $1 \mathrm{H})$. The obtained ${ }^{1} \mathrm{H}$ NMR spectral data were in good agreement with those previously reported. ${ }^{5}$

2-Nitropyren-1-yl trifluoromethanesulfonate (4). To a solution of 3 (670 $\mathrm{mg}, 2.55 \mathrm{mmol})$ in $\mathrm{CH}_{2} \mathrm{Cl}_{2}(50 \mathrm{~mL})$ was added $\mathrm{Et}_{3} \mathrm{~N}(1.0 \mathrm{~mL}, 7.65 \mathrm{mmol})$ at room temperature. The mixture was cooled to $0{ }^{\circ} \mathrm{C}$ and then trifluoromethanesulfonic anhydride $(0.47 \mathrm{~mL}, 2.8 \mathrm{mmol})$ was added dropwise over $5 \mathrm{~min}$. After stirring for $12 \mathrm{~h}$ at $\mathrm{rt}$, the reaction mixture was quenched with $\mathrm{H}_{2} \mathrm{O}$ (10 $\mathrm{mL})$, then the layers were separated. The aqueous layer was extracted with $\mathrm{CH}_{2} \mathrm{Cl}_{2}(50 \mathrm{~mL} \times 3)$ and the combined organic layer was washed with $3 \mathrm{~N} \mathrm{HCl}$ and then dried over $\mathrm{Na}_{2} \mathrm{SO}_{4}$ and then filtered. The solvent was evaporated under reduced pressure and the crude material purified by flash column chromatography (4:1 hexane/ $\left.\mathrm{CH}_{2} \mathrm{Cl}_{2}\right)$ to afford $4(757 \mathrm{mg}, 86 \%)$ as an amorphous yellow solid. $R_{\mathrm{f}}=0.37\left(4: 1\right.$ hexane $\left./ \mathrm{CH}_{2} \mathrm{Cl}_{2}\right) .{ }^{1} \mathrm{H} \mathrm{NMR}\left(500 \mathrm{MHz}, \mathrm{CDCl}_{3}\right) \delta 8.78(\mathrm{~s}, 1 \mathrm{H}), 8.38-$ $8.33(\mathrm{~m}, 4 \mathrm{H}), 8.25(\mathrm{~d}, J=8.9 \mathrm{~Hz}, 1 \mathrm{H}), 8.21(\mathrm{t}, J=7.7 \mathrm{~Hz}, 1 \mathrm{H}), 8.11(\mathrm{~d}, J=8.9 \mathrm{~Hz}, 1 \mathrm{H}) .{ }^{13} \mathrm{C}\left\{{ }^{1} \mathrm{H}\right\}$ NMR $\left(126 \mathrm{MHz}, \mathrm{CDCl}_{3}\right) \delta 139.6,133.1,131.7,131.6,131.1,130.8,130.4,128.8,127.9,127.5$, 127.3, 126.7, 125.7, 123.3, 120.6, 120.2, $118.8(\mathrm{q}, J=320.8 \mathrm{~Hz}) .{ }^{19} \mathrm{~F}\left\{{ }^{1} \mathrm{H}\right\} \mathrm{NMR}\left(471 \mathrm{MHz}, \mathrm{CDCl}_{3}\right)$ $\delta$-72.5. HRMS (ESI) $m / z$ calcd for $\mathrm{C}_{17} \mathrm{H}_{9} \mathrm{~F}_{3} \mathrm{NO}_{5} \mathrm{~S}[\mathrm{M}+\mathrm{H}]^{+}$396.0154, found 396.0145.

1-(Hex-1-ynyl)pyren-2-amine (5a). To an $\mathrm{N}_{2}$-degassed solution of 4 (116 mg, $\left.0.34 \mathrm{mmol}\right)$ and 1-hexyne $(0.12 \mathrm{~mL}, 1 \mathrm{mmol})$ in $5: 1(\mathrm{v} / \mathrm{v}) \mathrm{THF} / \mathrm{Et}_{3} \mathrm{~N}(30 \mathrm{~mL})$ was added $\mathrm{CuI}(2 \mathrm{mg}, 0.002$ mmol) and $\mathrm{Pd}\left(\mathrm{PPh}_{3}\right)_{2} \mathrm{Cl}_{2}(21 \mathrm{mg}, 0.03 \mathrm{mmol})$. The solution was stirred at $80{ }^{\circ} \mathrm{C}$ (oil bath) under $\mathrm{N}_{2}$ for $12 \mathrm{~h}$, then the reaction mixture was diluted with $\mathrm{CH}_{2} \mathrm{Cl}_{2}$ and filtered through a $4 \mathrm{~cm}$ pad of silica. The filtrate was concentrated under reduced pressure and the crude product purified by flash chromatography (hexanes/EtOAc/ $\left.\mathrm{CH}_{2} \mathrm{Cl}_{2}, 20: 1: 1\right)$ over silica to give a brown oil. $R_{\mathrm{f}}=0.47$ (4:1 hexane $\left./ \mathrm{CH}_{2} \mathrm{Cl}_{2}\right)$. This oil was then dissolved in $\mathrm{AcOH}(10 \mathrm{~mL})$, actived $\mathrm{Zn}$ powder $(221 \mathrm{mg}, 3.4$ mmol) was added and the mixture stirred at r.t. for $1 \mathrm{~h} . \mathrm{H}_{2} \mathrm{O}(20 \mathrm{~mL})$ was added and the aqueous layer extracted with $\mathrm{CH}_{2} \mathrm{Cl}_{2}(20 \mathrm{~mL} \times 2)$. The combined organic layer was washed with satd $\mathrm{NaHCO}_{3}$ soln and dried over $\mathrm{Na}_{2} \mathrm{SO}_{4}$. Following evaporation of the solvent under reduced pressure, the crude residue was purified by flash column chromatography (hexane/EtOAc/ $\mathrm{CH}_{2} \mathrm{Cl}_{2}$, 16:1:1) to afford $\mathbf{5 a}(84 \mathrm{mg}, 83 \%)$ as a yellow solid. $R_{\mathrm{f}}=0.24$ (8:1 hexane/EtOAc). M.p. 153-156 
${ }^{\circ} \mathrm{C} .{ }^{1} \mathrm{H}$ NMR $\left(500 \mathrm{MHz}, \mathrm{CDCl}_{3}\right) \delta 8.41(\mathrm{~d}, J=9.1 \mathrm{~Hz}, 1 \mathrm{H}), 8.11(\mathrm{~d}, J=7.6 \mathrm{~Hz}, 1 \mathrm{H}), 8.08-8.07$ (m, 2H), $7.95(\mathrm{~d}, J=8.9 \mathrm{~Hz}, 1 \mathrm{H}), 7.86(\mathrm{t}, J=7.6 \mathrm{~Hz}, 1 \mathrm{H}), 7.81(\mathrm{~d}, J=8.9 \mathrm{~Hz}, 1 \mathrm{H}), 7.47$ (s, 1H), $4.65(\mathrm{~s}, 2 \mathrm{H}), 2.72(\mathrm{t}, J=7.1 \mathrm{~Hz}, 2 \mathrm{H}), 1.81-1.76(\mathrm{~m}, 2 \mathrm{H}), 1.66-1.61(\mathrm{~m}, 2 \mathrm{H}), 1.04(\mathrm{t}, J=7.3 \mathrm{~Hz}$, $3 \mathrm{H}) .{ }^{13} \mathrm{C}\left\{{ }^{1} \mathrm{H}\right\} \mathrm{NMR}\left(126 \mathrm{MHz}, \mathrm{CDCl}_{3}\right) \delta 146.3,132.9,131.9,130.1,129.9,128.5,128.3,126.4$, 125.6, 125.5, 125.2, 124.7, 124.6, 110.4, 110.3, 102.0, 76.0, 31.4, 22.4, 20.0, 13.9. HRMS (ESI) $m / z$ calcd for $\mathrm{C}_{22} \mathrm{H}_{20} \mathrm{~N}[\mathrm{M}+\mathrm{H}]^{+}$298.1596, found 298.1640.

1-((3,5-Bis(trifluoromethyl)phenyl)ethynyl)pyren-2-amine (5b). To an $\mathrm{N}_{2}$-degassed solution of 4 (240 mg, $0.69 \mathrm{mmol})$ and 3,5-bis(trifluoromethyl)phenylethyne ${ }^{2}(310 \mathrm{mg}, 1.04 \mathrm{mmol})$ in 5:1 (v/v) THF/Et $3 \mathrm{~N}(30 \mathrm{~mL})$ was added $\mathrm{CuI}(13 \mathrm{mg}, 0.07 \mathrm{mmol})$ and $\mathrm{Pd}\left(\mathrm{PPh}_{3}\right)_{2} \mathrm{Cl}_{2}(50 \mathrm{mg}, 0.07 \mathrm{mmol})$. The solution was stirred at $80^{\circ} \mathrm{C}$ (oil bath) under $\mathrm{N}_{2}$ for $12 \mathrm{~h}$, then the reaction mixture was diluted with $\mathrm{CH}_{2} \mathrm{Cl}_{2}$ and filtered through a $4 \mathrm{~cm}$ pad of silica. The filtrate was concentrated under reduced pressure and the crude product purified by flash chromatography (hexanes/EtOAc, 30:1) over silica to give a brown oil. $R_{\mathrm{f}}=0.31\left(20: 1\right.$ hexane $\left./ \mathrm{CH}_{2} \mathrm{Cl}_{2}\right)$. This oil was then dissolved in $\mathrm{AcOH}$ $(10 \mathrm{~mL}$ ), actived $\mathrm{Zn}$ powder (455 mg, $7 \mathrm{mmol}$ ) was added, and the mixture stirred at r.t. for $1 \mathrm{~h}$. $\mathrm{H}_{2} \mathrm{O}(20 \mathrm{~mL})$ was added and the aqueous layer extracted with $\mathrm{CH}_{2} \mathrm{Cl}_{2}(30 \mathrm{~mL} \times 2)$. The combined organic layer was washed with saturated $\mathrm{NaHCO}_{3}$ solution and dried over $\mathrm{Na}_{2} \mathrm{SO}_{4}$. Following evaporation of the solvent under reduced pressure, the crude residue was purified by flash column chromatography (hexanes/EtOAc, 8:1) to afford $\mathbf{5 b}(227 \mathrm{mg}, 72 \%)$ as a yellow solid. $R_{\mathrm{f}}=0.24$ (8:1 hexane/EtOAc). M.p. $113-115{ }^{\circ} \mathrm{C} .{ }^{1} \mathrm{H}$ NMR $\left(500 \mathrm{MHz}, \mathrm{CDCl}_{3}\right) \delta 8.41(\mathrm{~d}, J=9.0 \mathrm{~Hz}, 1 \mathrm{H})$, $8.15(\mathrm{t}, J=8.0 \mathrm{~Hz}, 2 \mathrm{H}), 8.11-8.08(\mathrm{~m}, 3 \mathrm{H}), 7.99$ (d, $J=8.9 \mathrm{~Hz}, 1 \mathrm{H}), 7.91-7.87(\mathrm{~m}, 2 \mathrm{H}), 7.81$ (d, $J=8.9 \mathrm{~Hz}, 1 \mathrm{H}), 7.45(\mathrm{~s}, 1 \mathrm{H}), 4.71(\mathrm{~s}, 2 \mathrm{H}) .{ }^{13} \mathrm{C}\left\{{ }^{1} \mathrm{H}\right\} \mathrm{NMR}\left(126 \mathrm{MHz}, \mathrm{CDCl}_{3}\right) \delta 146.9,133.5,133.4$, 132.3 (q, $J=33.7 \mathrm{~Hz}), 131.3$ (q, $J=3.7 \mathrm{~Hz}), 130.0,129.8,129.5,129.4,126.4,126.2,126.0,125.0$, $124.6,123.2(\mathrm{q}, J=273.0 \mathrm{~Hz}), 121.6(\mathrm{q}, J=3.8 \mathrm{~Hz}), 121.6,118.8,110.5,101.6,97.5,89.0 .{ }^{19} \mathrm{~F}\left\{{ }^{1} \mathrm{H}\right\}$ $\operatorname{NMR}\left(471 \mathrm{MHz}, \mathrm{CDCl}_{3}\right) \delta-63.0$. HRMS (ESI) $m / z$ calcd for $\mathrm{C}_{26} \mathrm{H}_{14} \mathrm{~F}_{6} \mathrm{~N}[\mathrm{M}+\mathrm{H}]^{+} 454.1030$, found 454.1023.

Iodoheterocycle 6a. To a solution of aniline $\mathbf{5 a}(58 \mathrm{mg}, 0.19 \mathrm{mmol})$ in dry pyridine $(1 \mathrm{~mL})$ was added $\mathrm{PPh}(\mathrm{OPh})_{2}(115 \mathrm{mg}, 0.39 \mathrm{mmol})$. The reaction flask was sealed and heated to $110{ }^{\circ} \mathrm{C}$ for $24 \mathrm{~h}$. After cooling, toluene $(20 \mathrm{~mL})$ was added and the volatiles were removed in vacuo. The residue was dissolved in $\mathrm{THF} / \mathrm{H}_{2} \mathrm{O}$ mixture $(10 \mathrm{~mL}, \mathrm{v} / \mathrm{v}, 20: 1)$. After heating at $60{ }^{\circ} \mathrm{C}$ (water bath) for $1 \mathrm{~h}$, the THF layer was dried $\left(\mathrm{Na}_{2} \mathrm{SO}_{4}\right)$, filtered and the solvent removed under reduced pressure. The crude residue was purified by flash chromatography $\left(\mathrm{CH}_{2} \mathrm{Cl}_{2} / \mathrm{EtOAc}, 2: 1\right)$ over silica to give a brown oil. $R_{\mathrm{f}}=0.21\left(2: 1 \mathrm{CH}_{2} \mathrm{Cl}_{2} / \mathrm{EtOAc}\right)$. This oil was dissolved in AcOH $(5 \mathrm{~mL})$ and TFA $(0.05$ 
$\mathrm{mL}$ ) added. NIS (47 mg, $0.2 \mathrm{mmol}$ ) was added and the mixture stirred for $1 \mathrm{~h}$ at $\mathrm{r} . \mathrm{t}$. The mixture was washed with saturated $\mathrm{NaS}_{2} \mathrm{O}_{3}(2 \times 15 \mathrm{~mL})$ and brine $(15 \mathrm{~mL})$ solutions, dried $\left(\mathrm{MgSO}_{4}\right)$ and evaporated. The crude product was purified by chromatography over silica $\left(\mathrm{CH}_{2} \mathrm{Cl}_{2} / \mathrm{EtOAc}, 5: 1\right)$ to give $6 \mathbf{a}(65 \mathrm{mg}, 62 \%)$ as a yellow solid. $R_{\mathrm{f}}=0.72\left(2: 1 \mathrm{CH}_{2} \mathrm{Cl}_{2} / \mathrm{EtOAc}\right)$. M.p. $>200{ }^{\circ} \mathrm{C} .{ }^{1} \mathrm{H} \mathrm{NMR}$ $\left(500 \mathrm{MHz}, \mathrm{CDCl}_{3}\right) \delta 8.52(\mathrm{~d}, J=9.4 \mathrm{~Hz}, 1 \mathrm{H}), 8.37(\mathrm{~d}, J=34.3 \mathrm{~Hz}, 1 \mathrm{H}), 8.28(\mathrm{~d}, J=9.2 \mathrm{~Hz}, 1 \mathrm{H})$, 8.23-8.20 (m, 3H), 8.10 (d, $J=9.3 \mathrm{~Hz}, 1 \mathrm{H}), 7.99$ (t, $J=7.6 \mathrm{~Hz}, 1 \mathrm{H}), 7.92-7.87$ (m, 2H), 7.61$7.58(\mathrm{~m}, 1 \mathrm{H}), 7.50-7.54(\mathrm{~m}, 2 \mathrm{H}), 7.18(\mathrm{~s}, 1 \mathrm{H}), 2.64-2.50(\mathrm{~m}, 2 \mathrm{H}), 1.76-1.67(\mathrm{~m}, 1 \mathrm{H}), 1.66-1.56$ $(\mathrm{m}, 1 \mathrm{H}), 1.44-1.33(\mathrm{~m}, 2 \mathrm{H}), 0.90(\mathrm{t}, J=7.4 \mathrm{~Hz}, 3 \mathrm{H}) .{ }^{13} \mathrm{C}\left\{{ }^{1} \mathrm{H}\right\} \mathrm{NMR}\left(151 \mathrm{MHz}, \mathrm{CDCl}_{3}\right) \delta 137.4$ $(\mathrm{d}, J=2.8 \mathrm{~Hz}), 134.2,133.3(\mathrm{~d}, J=4.1 \mathrm{~Hz}), 132.8,132.8,132.7(\mathrm{~d}, J=2.8 \mathrm{~Hz}), 132.4,131.8$, $131.0,130.2$, 130.0, 129.9, 129.6, 129.5, 129.1, 128.8, 128.7, 126.8, 126.8, 125.9, 124.0, 121.3, 121.1, 113.8 (d, $J=11.8 \mathrm{~Hz}), 92.4$ (d, $J=7.3 \mathrm{~Hz}), 32.0$ (d, $J=4.5 \mathrm{~Hz}), 31.9$ (d, $J=12.0 \mathrm{~Hz}), 22.6$, 14.0. ${ }^{31} \mathrm{P}\left\{{ }^{1} \mathrm{H}\right\}$ NMR $\left(201 \mathrm{MHz}, \mathrm{CDCl}_{3}\right) \delta$ 13.5. HRMS (ESI) $m / z$ calcd for $\mathrm{C}_{28} \mathrm{H}_{24} \mathrm{INOP}[\mathrm{M}+\mathrm{H}]^{+}$ 548.0640, found 548.0629.

Iodoheterocycle $\mathbf{6 b}$. To a solution of aniline $\mathbf{5 b}(164 \mathrm{mg}, 0.36 \mathrm{mmol})$ in dry pyridine $(1 \mathrm{~mL})$ was added $\mathrm{PPh}(\mathrm{OPh})_{2}(213 \mathrm{mg}, 0.72 \mathrm{mmol})$. The reaction flask was sealed and heated to $110{ }^{\circ} \mathrm{C}$ for $24 \mathrm{~h}$. After cooling, toluene $(20 \mathrm{~mL})$ was added and the volatiles were removed in vacuo. The residue was dissolved in $\mathrm{THF} / \mathrm{H}_{2} \mathrm{O}$ mixture $(15 \mathrm{~mL}, \mathrm{v} / \mathrm{v}, 20: 1)$. After heating at $60{ }^{\circ} \mathrm{C}$ (water bath) for $1 \mathrm{~h}$, the THF layer was dried $\left(\mathrm{Na}_{2} \mathrm{SO}_{4}\right)$, filtered, and the solvent was concentrated under reduced pressure. The resulting crude product was purified by flash chromatography $\left(\mathrm{CH}_{2} \mathrm{Cl}_{2} / \mathrm{EtOAc}, 15: 1\right)$ over silica to give a brown oil. $R_{\mathrm{f}}=0.51\left(10: 1 \mathrm{CH}_{2} \mathrm{Cl}_{2} / \mathrm{EtOAc}\right)$. This oil was dissolved in $\mathrm{AcOH}$ $(5 \mathrm{~mL})$ and TFA $(0.05 \mathrm{~mL})$ added. NIS $(96 \mathrm{mg}, 0.43 \mathrm{mmol})$ was added and the mixture stirred for $1 \mathrm{~h}$ at r.t. The mixture was washed with saturated $\mathrm{NaS}_{2} \mathrm{O}_{3}(2 \times 15 \mathrm{~mL})$ and brine $(15 \mathrm{~mL})$ solutions, dried $\left(\mathrm{MgSO}_{4}\right)$ and evaporated. The crude product was purified by chromatography over silica $\left(\mathrm{CH}_{2} \mathrm{Cl}_{2} /\right.$ EtOAc, $\left.40: 1\right)$ to give $\mathbf{6 b}(205 \mathrm{mg}, 81 \%)$ as a yellow solid. $R_{\mathrm{f}}=0.83\left(2: 1 \mathrm{CH}_{2} \mathrm{Cl}_{2} / \mathrm{EtOAc}\right)$. M.p. $>200{ }^{\circ} \mathrm{C} .{ }^{1} \mathrm{H}$ NMR $\left(600 \mathrm{MHz}, \mathrm{THF}-d_{8}\right) \delta 8.99(\mathrm{~d}, J=30.0 \mathrm{~Hz}, 1 \mathrm{H}), 8.78(\mathrm{~d}, J=9.4 \mathrm{~Hz}, 1 \mathrm{H})$, 8.54 (s, 2H), 8.29-8.23 (m, 4H), 8.15-8.11 (m, 2H), 7.98 (t, J= 7.6 Hz, 1H), 7.90 (s, 1H), 7.85$7.81(\mathrm{~m}, 2 \mathrm{H}), 7.45-7.37(\mathrm{~m}, 3 \mathrm{H}) .{ }^{13} \mathrm{C}\left\{{ }^{1} \mathrm{H}\right\} \mathrm{NMR}\left(151 \mathrm{MHz}, \mathrm{THF}-d_{8}\right) \delta 140.0(\mathrm{~d}, J=12.7 \mathrm{~Hz})$, $138.8(\mathrm{~d}, J=2.9 \mathrm{~Hz}), 135.5(\mathrm{~d}, J=2.1 \mathrm{~Hz}), 135.4,134.1,133.2,132.7,132.6,131.9(\mathrm{~d}, J=2.7$ Hz), 131.7, 131.3 (q, $J=33.2 \mathrm{~Hz}$ ), 131.3, 130.3, 130.1, 129.9, 129.6, 128.3 (br q), 128.0, 128.0, 127.2, 127.0, 126.8, 126.4, 125.8, 123.6, 123.5 (q, $J=273.3 \mathrm{~Hz}), 121.4,120.9$ (br q), 120.7, 113.4 $(\mathrm{d}, J=10.7 \mathrm{~Hz}), 91.1(\mathrm{~d}, J=7.6 \mathrm{~Hz}) .{ }^{19} \mathrm{~F}\left\{{ }^{1} \mathrm{H}\right\} \mathrm{NMR}\left(471 \mathrm{MHz}, \mathrm{THF}-d_{8}\right) \delta-63.6 .{ }^{31} \mathrm{P}\left\{{ }^{1} \mathrm{H}\right\} \mathrm{NMR}$ $\left(243 \mathrm{MHz}, \mathrm{THF}-d_{8}\right) \delta$ 7.8. HRMS (ESI) $\mathrm{m} / z$ calcd for $\mathrm{C}_{32} \mathrm{H}_{18} \mathrm{~F}_{6} \mathrm{INOP}[\mathrm{M}+\mathrm{H}]^{+} 704.0075$, found 704.0060 . 
$P N$-Heterocycle 1a. To an $\mathrm{N}_{2}$-degassed solution of $6 \mathbf{a}(41 \mathrm{mg}, 0.07 \mathrm{mmol})$ and phenylacetylene $(90 \mathrm{mg}, 0.08 \mathrm{mmol})$ in 5:1 (v/v) THF/Et $3 \mathrm{~N}(6 \mathrm{~mL})$ was added $\mathrm{CuI}(1.5 \mathrm{mg}, 0.007 \mathrm{mmol})$ and $\mathrm{Pd}\left(\mathrm{PPh}_{3}\right)_{2} \mathrm{Cl}_{2}(14 \mathrm{mg}, 0.007 \mathrm{mmol})$. The solution was stirred at r.t. for $6 \mathrm{~h}$ and monitored by TLC [new spot: $R_{\mathrm{f}}=0.80\left(2: 1 \mathrm{CH}_{2} \mathrm{Cl}_{2} / \mathrm{EtOAc}\right)$ ]. After that, the mixture was heated at $80{ }^{\circ} \mathrm{C}$ (oil bath) under $\mathrm{N}_{2}$ for $2 \mathrm{~h}$, then the reaction mixture was diluted with $\mathrm{CH}_{2} \mathrm{Cl}_{2}$ and filtered through a $4 \mathrm{~cm}$ pad of silica. The filtrate was concentrated under reduced pressure and the residue purified by flash column chromatography (hexanes/EtOAc, $6: 1)$ to provide $1 \mathrm{a}(32 \mathrm{mg}, 87 \%)$ as a yellow solid. $R_{\mathrm{f}}=$ 0.25 (hexanes/EtOAc, 4:1). M.p. $>200{ }^{\circ} \mathrm{C} .{ }^{1} \mathrm{H}$ NMR $\left(600 \mathrm{MHz}, \mathrm{CDCl}_{3}\right) \delta 8.66(\mathrm{~d}, J=9.2 \mathrm{~Hz}, 1 \mathrm{H})$, $8.50(\mathrm{~d}, J=8.5 \mathrm{~Hz}, 1 \mathrm{H}), 8.48(\mathrm{~d}, J=35.5 \mathrm{~Hz}, 1 \mathrm{H}), 8.27-8.23(\mathrm{~m}, 3 \mathrm{H}), 8.18(\mathrm{~d}, J=9.2 \mathrm{~Hz}, 1 \mathrm{H})$, $8.01(\mathrm{t}, J=7.6 \mathrm{~Hz}, 1 \mathrm{H}), 7.61(\mathrm{dt}, J=6.9,1.4 \mathrm{~Hz}, 2 \mathrm{H}), 7.44(\mathrm{~d}, J=2.6 \mathrm{~Hz}, 1 \mathrm{H}), 7.33-7.24(\mathrm{~m}, 6 \mathrm{H})$, 7.18-7.14 (m, 2H), 2.63-2.51 (m, 2H), 1.83-1.76 (m, 1H), 1.69-1.62 (m, 1H), 1.45-1.35 (m, 2H), $0.90(\mathrm{t}, J=7.4 \mathrm{~Hz}, 4 \mathrm{H}) .{ }^{13} \mathrm{C}\left\{{ }^{1} \mathrm{H}\right\} \mathrm{NMR}\left(151 \mathrm{MHz}, \mathrm{CDCl}_{3}\right) \delta 144.9$ (d, $\left.J=1.8 \mathrm{~Hz}\right), 133.2,132.8$ (d, $J=3.7 \mathrm{~Hz}), 132.4,132.1,132.1,132.0,131.8,131.7,131.5,131.3,131.1,130.6,130.5,129.7$, $128.9,128.6,128.2,128.0,127.8,127.7,126.2,125.9,125.7,125.6,125.5,125.5,124.2$ (d, $J=$ $5.1 \mathrm{~Hz}), 123.7,121.8,121.7,111.9(\mathrm{~d}, J=10.2 \mathrm{~Hz}), 107.8(\mathrm{~d}, J=5.8 \mathrm{~Hz}), 32.5(\mathrm{~d}, J=3.9 \mathrm{~Hz})$, $32.1(\mathrm{~d}, J=12.6 \mathrm{~Hz}), 22.6,14.0 .{ }^{31} \mathrm{P}\left\{{ }^{1} \mathrm{H}\right\} \operatorname{NMR}\left(243 \mathrm{MHz}, \mathrm{CDCl}_{3}\right) \delta 14.8$. HRMS (ESI) $m / z$ calcd for $\mathrm{C}_{36} \mathrm{H}_{29} \mathrm{NOP}[\mathrm{M}+\mathrm{H}]^{+}$522.1987, found 522.1979.

$P N$-Heterocycle $\mathbf{1 b}$. A similar procedure was followed using $N, N$-diphenyl-4-ethynylaniline ${ }^{4}$ (22 mg, $0.08 \mathrm{mmol}$ ). Purification by column chromatography (silica gel, hexanes/EtOAc, 5:1) gave the crude product, which then further purified by preparative SEC to provide $1 \mathrm{~b}(30 \mathrm{mg}, 63 \%)$ as an amorphous orange powder. $R_{\mathrm{f}}=0.34$ (hexanes/EtOAc, 4:1). ${ }^{1} \mathrm{H}$ NMR $\left(500 \mathrm{MHz}, \mathrm{CD}_{2} \mathrm{Cl}_{2}\right) \delta$ $8.70(\mathrm{~d}, J=9.3 \mathrm{~Hz}, 1 \mathrm{H}), 8.55$ (d, $J=8.9 \mathrm{~Hz}, 1 \mathrm{H}), 8.49$ (d, $J=34.6 \mathrm{~Hz}, 1 \mathrm{H}), 8.29-8.25(\mathrm{~m}, 3 \mathrm{H})$, $8.20(\mathrm{~d}, J=9.3 \mathrm{~Hz}, 1 \mathrm{H}), 8.03$ (t, $J=7.6 \mathrm{~Hz}, 1 \mathrm{H}), 7.56-7.53(\mathrm{~m}, 2 \mathrm{H}), 7.49$ (d, $J=2.6 \mathrm{~Hz}, 1 \mathrm{H})$, 7.45-7.37 (m, 3H), 7.32-7.28 (m, 6H), 7.09-7.06 (m, 6H), 6.92-6.90 (m, 2H), 2.63-2.49 (m, 2H), 1.76-1.70 (m, 1H), 1.65-1.57 (m, 1H), 1.42-1.34 (m, 2H), $0.89(\mathrm{t}, J=7.4 \mathrm{~Hz}, 3 \mathrm{H}) .{ }^{13} \mathrm{C}\left\{{ }^{1} \mathrm{H}\right\} \mathrm{NMR}$ $\left(151 \mathrm{MHz}, \mathrm{CDCl}_{3}\right) \delta 148.1,147.6,144.9(\mathrm{~d}, J=2.0 \mathrm{~Hz}), 133.2,132.7$ (d, $\left.J=3.6 \mathrm{~Hz}\right), 132.5,132.2$, 132.1, 132.0, 131.6, 131.1, 130.6, 130.4, 129.6, 129.4, 128.8, 128.2, 128.1, 127.7, 126.1, 125.9 (d, $J=9.0 \mathrm{~Hz}), 125.6,125.5,125.4,125.4,124.6,124.3(\mathrm{~d}, J=5.2 \mathrm{~Hz}), 123.6,123.2,122.7,121.8$, 121.7, 111.8 (d, $J=10.1 \mathrm{~Hz}), 107.4(\mathrm{~d}, J=5.7 \mathrm{~Hz}), 32.5$ (d, $J=4.2 \mathrm{~Hz}), 32.0(\mathrm{~d}, J=12.7 \mathrm{~Hz})$, 22.6, 14.0. ${ }^{31} \mathrm{P}\left\{{ }^{1} \mathrm{H}\right\}$ NMR (202 MHz, $\left.\mathrm{CDCl}_{3}\right) \delta$ 14.0. HRMS (ESI) $m / z$ calcd for $\mathrm{C}_{48} \mathrm{H}_{38} \mathrm{~N}_{2} \mathrm{OP}$ $[\mathrm{M}+\mathrm{H}]^{+}$689.2722, found 689.2739. 
$P N$-Heterocycle 2a. To an $\mathrm{N}_{2}$-degassed solution of $\mathbf{6 b}(43 \mathrm{mg}, 0.06 \mathrm{mmol})$ and phenylacetylene $(61 \mathrm{mg}, 0.6 \mathrm{mmol})$ in 5:1 (v/v) THF/Et $3 \mathrm{~N}(6 \mathrm{~mL})$ was added CuI $(2 \mathrm{mg}, 0.006 \mathrm{mmol})$ and $\mathrm{Pd}\left(\mathrm{PPh}_{3}\right)_{2} \mathrm{Cl}_{2}(10 \mathrm{mg}, 0.006 \mathrm{mmol})$. The solution was stirred at room temperature for $8 \mathrm{~h}$ and monitored by TLC [new spot: $\left.R_{\mathrm{f}}=0.85\left(\mathrm{CH}_{2} \mathrm{Cl}_{2} / \mathrm{EtOAc}, 2: 1\right)\right]$. After that, the solution was stirred at $65^{\circ} \mathrm{C}$ (oil bath) under $\mathrm{N}_{2}$ for $2 \mathrm{~h}$, then the reaction mixture was diluted with $\mathrm{CH}_{2} \mathrm{Cl}_{2}$ and filtered through a $4 \mathrm{~cm}$ pad of silica. The filtrate was concentrated under reduced pressure and the residue purified by flash column chromatography (hexanes/EtOAc, 6:1) to provide $\mathbf{2 a}(33 \mathrm{mg}, 81 \%$ ) as an orange-yellow oil. $R_{\mathrm{f}}=0.34$ (hexanes/EtOAc, 5:1). ${ }^{1} \mathrm{H}$ NMR $\left(600 \mathrm{MHz}, \mathrm{CDCl}_{3}\right) \delta 8.79$ (d, $J=$ $30.8 \mathrm{~Hz}, 1 \mathrm{H}), 8.69$ (d, $J=9.2 \mathrm{~Hz}, 1 \mathrm{H}), 8.52$ (d, $J=8.8 \mathrm{~Hz}, 1 \mathrm{H}), 8.33-8.30(\mathrm{~m}, 3 \mathrm{H}), 8.25$ (d, $J=$ $9.2 \mathrm{~Hz}, 1 \mathrm{H}), 8.22(\mathrm{~s}, 2 \mathrm{H}), 8.06(\mathrm{t}, J=7.6 \mathrm{~Hz}, 1 \mathrm{H}), 7.78(\mathrm{~s}, 1 \mathrm{H}), 7.58-7.57(\mathrm{~m}, 2 \mathrm{H}), 7.50(\mathrm{~d}, J=$ $2.8 \mathrm{~Hz}, 1 \mathrm{H}), 7.30-7.22(\mathrm{~m}, 6 \mathrm{H}), 7.11-7.08(\mathrm{~m}, 2 \mathrm{H}) .{ }^{13} \mathrm{C}\left\{{ }^{1} \mathrm{H}\right\} \mathrm{NMR}\left(151 \mathrm{MHz}, \mathrm{CDCl}_{3}\right) \delta 144.8(\mathrm{~d}$, $J=2.8 \mathrm{~Hz}), 139.7(\mathrm{~d}, J=13.3 \mathrm{~Hz}), 135.8(\mathrm{~d}, J=2.3 \mathrm{~Hz}), 133.2,132.5(\mathrm{~d}, J=2.8 \mathrm{~Hz}), 132.0(\mathrm{q}, J$ $=33.2 \mathrm{~Hz}), 131.9,131.8,131.7,131.6,131.3,131.0,130.7,130.5,130.1,128.9(\mathrm{~d}, J=4.4 \mathrm{~Hz})$, 128.8, $128.2(\mathrm{~d}, J=14.3 \mathrm{~Hz}), 127.8,127.2,127.2,127.0,127.0,126.6,126.2,125.8,125.6,124.1$ (d, $J=5.5 \mathrm{~Hz}), 123.6,123.3$ (q, $J=273.3 \mathrm{~Hz}), 122.4,121.8$ (brq), 121.4, 111.0 (d, $J=8.9 \mathrm{~Hz})$, $108.4(\mathrm{~d}, J=6.0 \mathrm{~Hz}) .{ }^{19} \mathrm{~F}\left\{{ }^{1} \mathrm{H}\right\} \mathrm{NMR}\left(471 \mathrm{MHz}, \mathrm{CDCl}_{3}\right) \delta-62.8 .{ }^{31} \mathrm{P}\left\{{ }^{1} \mathrm{H}\right\} \mathrm{NMR}\left(243 \mathrm{MHz}, \mathrm{CDCl}_{3}\right)$ $\delta$ 11.8. HRMS (ESI) $m / z$ calcd for $\mathrm{C}_{40} \mathrm{H}_{23} \mathrm{~F}_{6} \mathrm{NOP}[\mathrm{M}+\mathrm{H}]^{+}$678.1421, found 678.1426.

$P N$-Heterocycle $\mathbf{2 b}$. A similar procedure was followed using $N, N$-diphenyl-4-ethynylaniline (20 mg, $0.07 \mathrm{mmol}$ ). Purification by column chromatography (hexanes/EtOAc, 12:1) on silica gave the crude product, which then further purified by preparative SEC to provide $\mathbf{2 b}$ ( $34 \mathrm{mg}, 67 \%$ ) as an orange-red oil. $R_{\mathrm{f}}=0.40$ (hexanes/EtOAc, 5:1). ${ }^{1} \mathrm{H}$ NMR $\left(500 \mathrm{MHz}, \mathrm{CDCl}_{3}\right) \delta 8.74(\mathrm{~d}, J=$ $30.8 \mathrm{~Hz}, 1 \mathrm{H}), 8.63(\mathrm{~d}, J=9.3 \mathrm{~Hz}, 1 \mathrm{H}), 8.48(\mathrm{~d}, J=8.9 \mathrm{~Hz}, 1 \mathrm{H}), 8.31-8.27(\mathrm{~m}, 3 \mathrm{H}), 8.22-8.20(\mathrm{~m}$, $3 \mathrm{H}), 8.05(\mathrm{t}, J=7.6 \mathrm{~Hz}, 1 \mathrm{H}), 7.80(\mathrm{~s}, 1 \mathrm{H}), 7.50-7.48(\mathrm{~m}, 3 \mathrm{H}), 7.41-7.33(\mathrm{~m}, 3 \mathrm{H}), 7.32-7.28(\mathrm{~m}$, 4H), 7.23-7.20 (m, 2H), 7.09-7.06 (m, 6H), 6.93-6.90 (m, 2H). ${ }^{13} \mathrm{C}\left\{{ }^{1} \mathrm{H}\right\} \mathrm{NMR}\left(151 \mathrm{MHz}, \mathrm{CDCl}_{3}\right)$ $\delta$ 148.4, 147.5, 144.9 (d, $J=2.5 \mathrm{~Hz}), 139.7$ (d, $J=13.3 \mathrm{~Hz}), 135.7$ (d, $J=2.1 \mathrm{~Hz}), 133.2,132.5$ (d, $J=2.8 \mathrm{~Hz}), 132.3,132.2,132.1,132.0$ (q, $J=33.2 \mathrm{~Hz}), 131.8,130.9,130.9,130.4,130.0$, 129.4, 128.8, 128.7, 128.3, 128.2, 127.0, 127.0, 126.8, 126.5, 126.2, 125.8, 125.6, 125.2, 124.7, 124.2 (d, $J=5.5 \mathrm{~Hz}), 123.6,123.4,123.3$ (q, $J=273.3 \mathrm{~Hz}), 122.5,121.8$ (brq), 121.7, 121.4, 110.9 $(\mathrm{d}, J=9.0 \mathrm{~Hz}), 108.0(\mathrm{~d}, J=6.0 \mathrm{~Hz}) \cdot{ }^{19} \mathrm{~F}\left\{{ }^{1} \mathrm{H}\right\} \mathrm{NMR}\left(471 \mathrm{MHz}, \mathrm{CDCl}_{3}\right) \delta-62.8 .{ }^{31} \mathrm{P}\left\{{ }^{1} \mathrm{H}\right\} \mathrm{NMR}$ $\left(202 \mathrm{MHz}, \mathrm{CDCl}_{3}\right) \delta$ 11.4. HRMS (ESI) $\mathrm{m} / z$ calcd for $\mathrm{C}_{52} \mathrm{H}_{32} \mathrm{~F}_{6} \mathrm{~N}_{2} \mathrm{OP}[\mathrm{M}+\mathrm{H}]^{+}$845.2156, found 845.2175 . 


\section{X-ray Structure Data and Molecular Packing}

Diffraction intensities for $1 \mathbf{a}$ were collected at $173 \mathrm{~K}$ on a Bruker Apex 2 CCD diffractometer using $\mathrm{CuK} \alpha$ radiation, $\lambda=1.54178 \AA$. Space group was determined based on systematic absences. Absorption corrections were applied by SADABS. ${ }^{6}$ Structure was solved by direct methods and Fourier techniques and refined on $F^{2}$ using full matrix least-squares procedures. All non-H atoms were refined with anisotropic thermal parameters. All $\mathrm{H}$ atoms in the structure were found from the residual density map and refined without any restrictions with isotropic thermal parameters. All calculations were performed by the Bruker SHELXL-2014 package. ${ }^{7}$ CCDC 1936450 contains the supplementary crystallographic data for this paper. These data can be obtained free of charge from The Cambridge Crystallographic Data Centre at www.ccdc.cam.ac.uk/data_request/cif.

Crystallographic data for $1 \mathrm{a}: \mathrm{C}_{36} \mathrm{H}_{28} \mathrm{NOP}, \mathrm{M}=521.56,0.09 \times 0.08 \times 0.06 \mathrm{~mm}, \mathrm{~T}=173(2)$ $\mathrm{K}$, Monoclinic, space group $P 2{ }_{1} / c, a=8.6693(4) \AA, b=19.7886(8) \AA, c=15.5913(7) \AA, \beta=$ $98.068(2)^{\circ}, V=2648.3(2) \AA^{3}, Z=4, D_{\mathrm{c}}=1.308 \mathrm{Mg} / \mathrm{m}^{3}, \mu(\mathrm{Cu})=1.150 \mathrm{~mm}^{-1}, F(000)=1096,2 \theta_{\max }$ $=133.11^{\circ}, 24252$ reflections, 4670 independent reflections $\left[\mathrm{R}_{\mathrm{int}}=0.0572\right], \mathrm{R} 1=0.03681, \mathrm{wR} 2=$ 0.0987 and $\mathrm{GOF}=1.029$ for 4670 reflections (464 parameters) with $\mathrm{I}>2 \sigma(\mathrm{I}), \mathrm{R} 1=0.0438, \mathrm{wR} 2=$ 0.1045 and $\mathrm{GOF}=1.029$ for all reflections, $\mathrm{max} / \mathrm{min}$ residual electron density $+0.286 /-0.381$ e $\AA^{-3}$. CCDC 1936450.

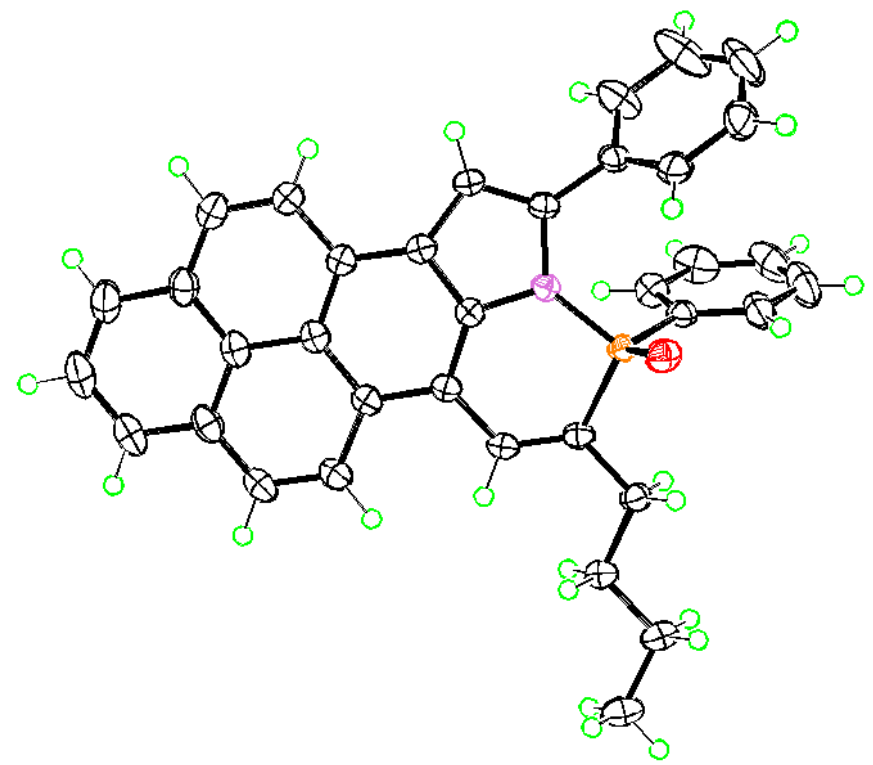

Figure S1. ORTEP drawing of the structure of 1a (thermal ellipsoids drawn at 50\% probability). Single crystal suitable for X-ray diffraction were obtained by diffusing $n$-hexanes into $\mathrm{CHCl}_{3}$ solution at room temperature. 
(a)

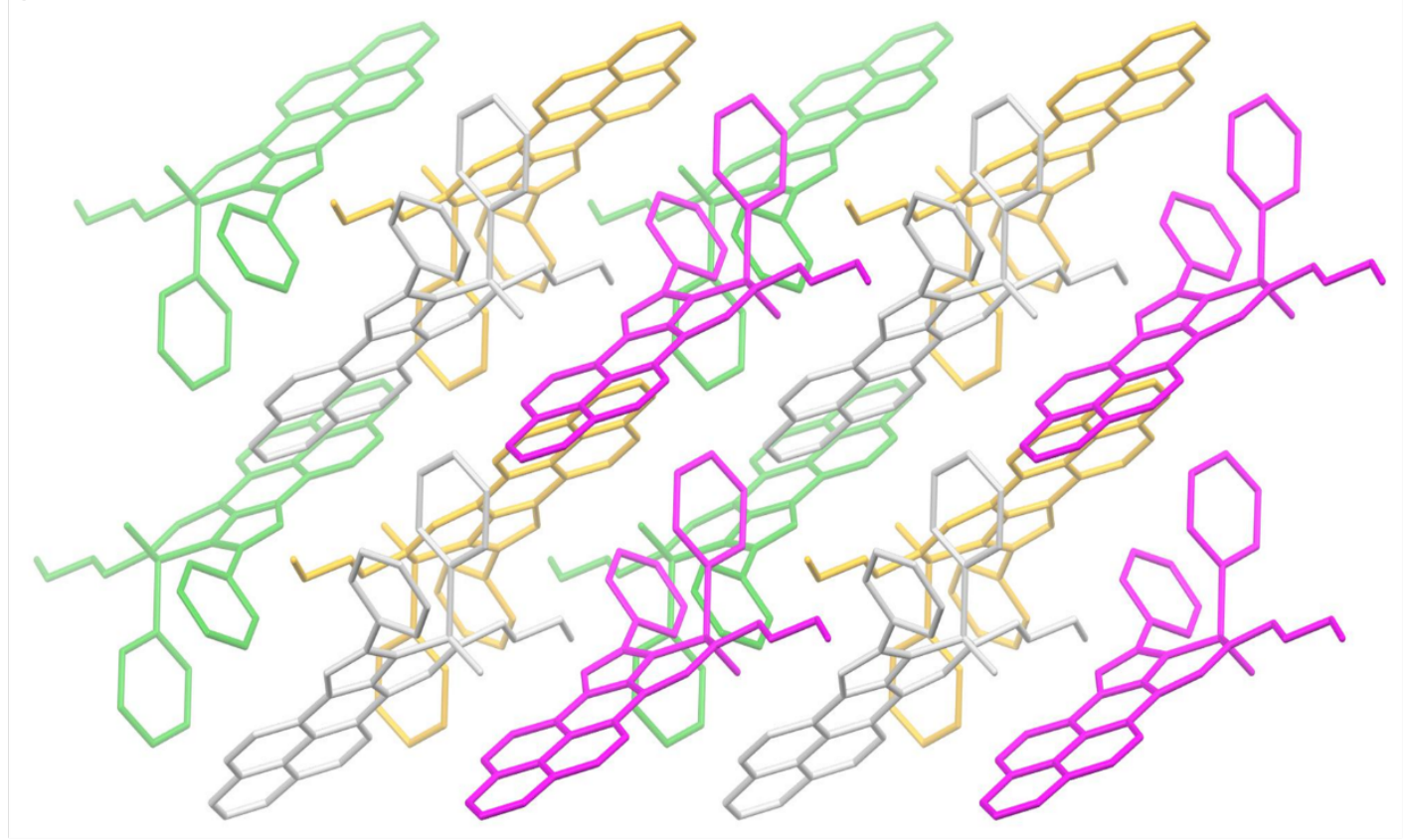

(b)

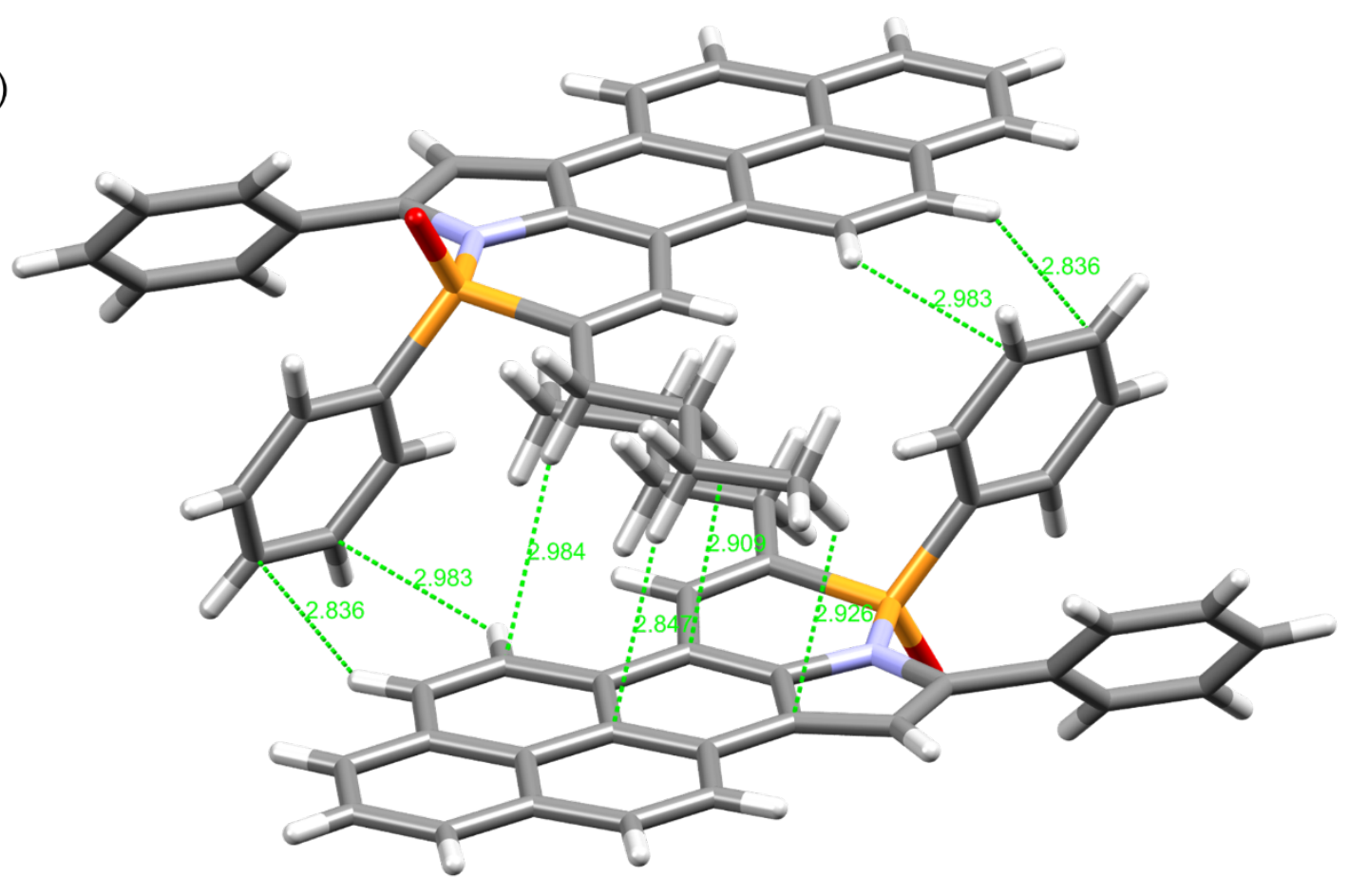


(c)

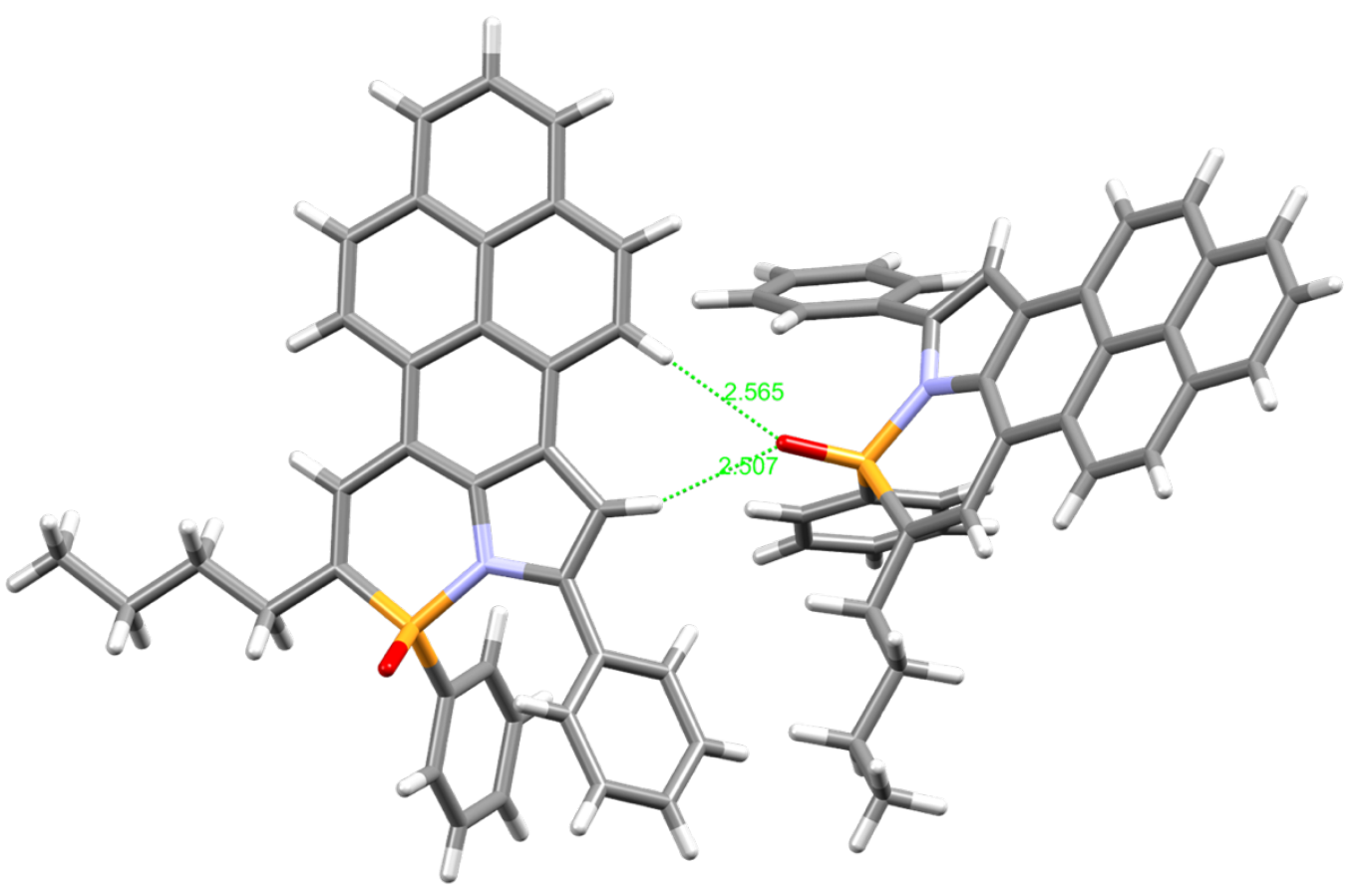

Figure S2. (a) Packing diagram of 1a as viewed along the $b$ axis. (b) The multiple $\mathrm{C}-\mathrm{H} \cdots \pi$ and (c) $\mathrm{C}-\mathrm{H} \cdots \mathrm{O}=\mathrm{P}$ intermolecular interactions in the unit cell. Distances in $\AA$. 


\section{Photophysical Properties}

UV/Vis data were obtained on an HP $8453 \mathrm{UV} /$ Vis spectrometer. Fluorescence data were acquired with a Horiba Jobin-Yvon FluoroMax-4 fluorescence spectrophotometer. Dilute solutions in degassed spectral grade $\mathrm{CHCl}_{3}$ in a $1 \mathrm{~cm}$ quartz cell were used for measurements. Absorption coefficients taken from the slope of the Beer's Law plot. Photoluminescence quantum yields were calculated by comparison with freshly prepared quinine sulfate in $0.5 \mathrm{M} \mathrm{H}_{2} \mathrm{SO}_{4}\left(\Phi_{\mathrm{F}}=\right.$ $0.55, \lambda_{\text {ex }}=366 \mathrm{~nm}$, for emission maxima $\sim 450 \mathrm{~nm}$ ), fluorescein in $0.1 \mathrm{M} \mathrm{NaOH}$ (aq.) $\left(\Phi_{\mathrm{F}}=0.91\right.$, $\lambda_{\mathrm{ex}}=470 \mathrm{~nm}$, for emission maxima $\left.\sim 530 \mathrm{~nm}\right)$, Rhodamine $6 \mathrm{G}$ in $\mathrm{EtOH}\left(\Phi_{\mathrm{F}}=0.95, \lambda_{\mathrm{ex}}=480 \mathrm{~nm}\right.$, for emission maxima $\sim 550 \mathrm{~nm})$ and Nile Red in dioxane $\left(\Phi_{\mathrm{F}}=0.70, \lambda_{\mathrm{ex}}=460 \mathrm{~nm}\right.$, for emission maxima $\sim 600 \mathrm{~nm}$ ) using an excitation slit width of $2 \mathrm{~nm}$ for all samples. To minimize the reabsorption effects, the absorbance in the $10 \mathrm{~mm}$ fluorescence cuvette was about $0.03 \sim 0.05$ at their excitation wavelengths. The absolute photoluminescence quantum yield of colloidal sample of $\mathbf{2 b}$ (in THF/water, 2/98, v/v) was measured using the Hamamatsu absolute PL quantum yield measurement system, the error is within $\pm 1 \%$.

Fluorescence lifetimes were measured using time correlated single photon counting (TCSPC). Dilute solutions were prepared and placed in a $1 \mathrm{~cm}$ optical path quartz cuvette. A pulsed nanoLED was used to excite the samples at $344 \mathrm{~nm}$ at a $1 \mathrm{MHz}$ repetition rate. The emission was detected via a longpass filter. For bi-exponential or tri-exponential decay histograms, the average fluorescence lifetime ( $\left.\tau_{\text {avg }}\right)$ is utilized and calculated based on the following equation: ${ }^{8}$

$$
\tau_{\mathrm{avg}}=\left(\sum \alpha_{i} \tau_{i}^{2} / \sum \alpha_{i} \tau_{i}\right)
$$

in which $\alpha_{\mathrm{i}}$ is the pre-exponential factor corresponding to the $\mathrm{i}^{\text {th }}$ decay time constant, $\tau_{i}$. The radiative rate constant $k_{\mathrm{r}}$ and the non-radiative rate constant $k_{\mathrm{nr}}$ were estimated by using the equations $k_{\mathrm{r}}=\Phi_{\mathrm{F}} / \tau_{\mathrm{F}}$ and $k_{\mathrm{nr}}=\left(1-\Phi_{\mathrm{F}}\right) / \tau_{\mathrm{F}}$, where $\Phi_{\mathrm{F}}$ is the photoluminescence quantum yield.

Solvent-dependent spectral shifts are interpreted in terms of the Lippert-Mataga plot, ${ }^{9}$ which describes the Stokes shift $\Delta v$ (between the maxima of absorption and fluorescence emission, in $\left.\mathrm{cm}^{-1}\right)$ as a function of the dipole moment change $\left(\Delta \mu=\mu_{\mathrm{e}}-\mu_{\mathrm{g}}\right): 8,9$

$$
\Delta v=\frac{2 \Delta f}{4 \pi \varepsilon_{0} h c a^{3}}(\Delta \mu)^{2}+\text { Constant }
$$

(in SI units)

where $\varepsilon_{0}$ is the permittivity of vacuum, $h$ is Planck's constant, $c$ is the velocity of light, $\Delta f$ is the solvent polarity function, and $a$ is the Onsager cavity radius. The Onsager cavity radius ( $a=7.0$ 
$\AA$ ) estimated from the quantum chemical calculation by using DFT method at the B3LYP/6$311 \mathrm{G}(\mathrm{d}, \mathrm{p})$ level. Thus, the dipole moment change $\left(\Delta \mu=\mu_{\mathrm{ex}}-\mu_{\mathrm{g}}\right)$ obtained from the solvatochromic shift is calculated to be $15.0 \mathrm{D}$ (Figure S12).

As the $\mathrm{S}_{0} \rightarrow \mathrm{S}_{1}$ transitions in substituted pyrene derivatives are usually broad with an undefined vibrational pattern, the band maxima of the longest absorption and emission have been used to determine the apparent Stokes shift in this study. In the case of 1,4-dioxane, the "effective" dielectric constant $\varepsilon$ is much higher as it adopts the boat conformation around dipolar species; while the protic solvent $\mathrm{MeOH}$ would interact with the strong hydrogen bond accepting $\mathrm{P}=\mathrm{O}$ moiety in the molecule via hydrogen bonding, thus these two solvents were excluded in the plot.

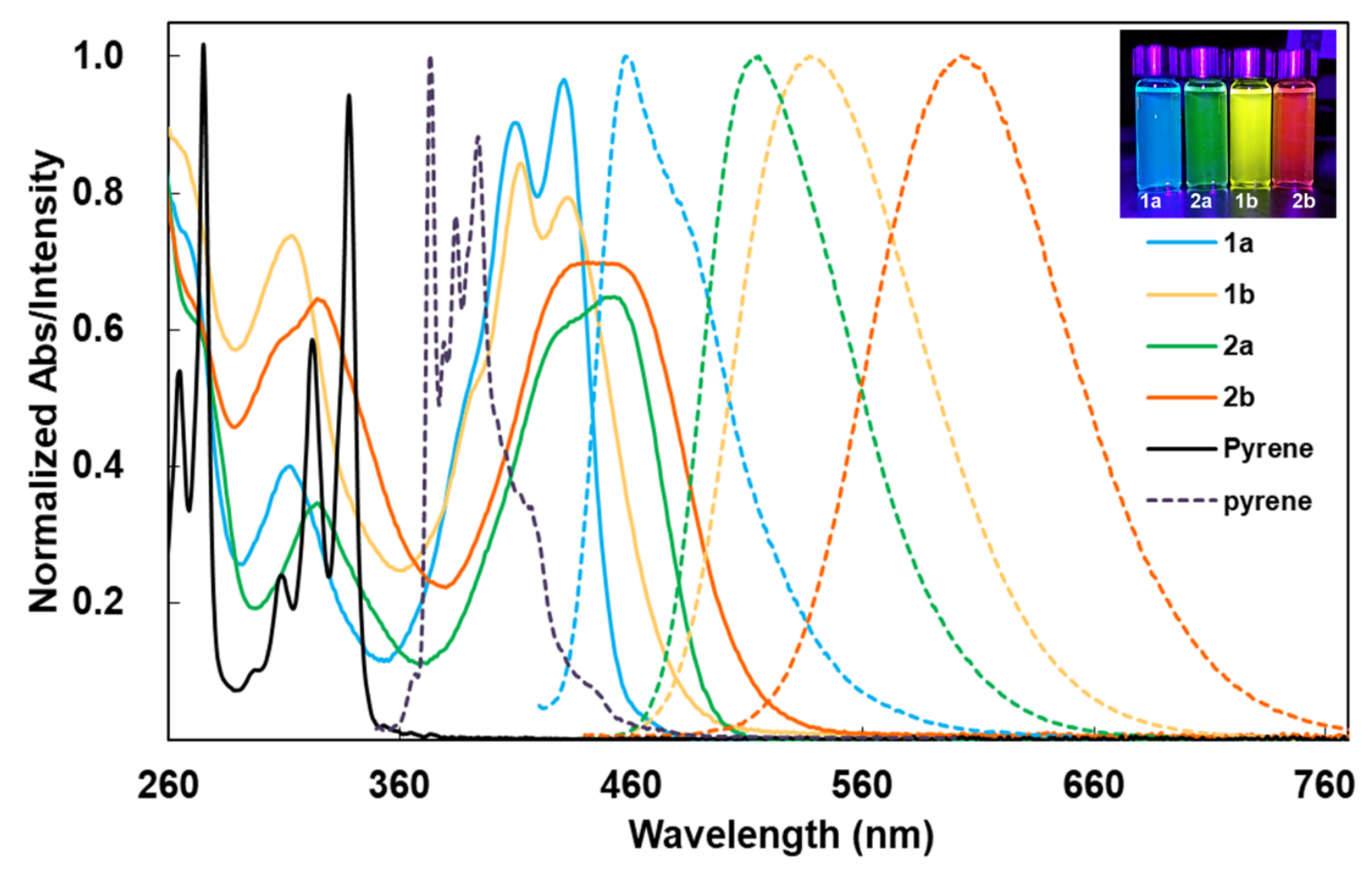

Figure S3. Absorption (solid lines) and fluorescence (dotted lines) spectra of $\mathbf{1}$ and $\mathbf{2}$ as well as pyrene in $\mathrm{CH}_{2} \mathrm{Cl}_{2}$ at $298 \mathrm{~K}$. Inset: emission color under $365 \mathrm{~nm} \mathrm{UV}$ light. 

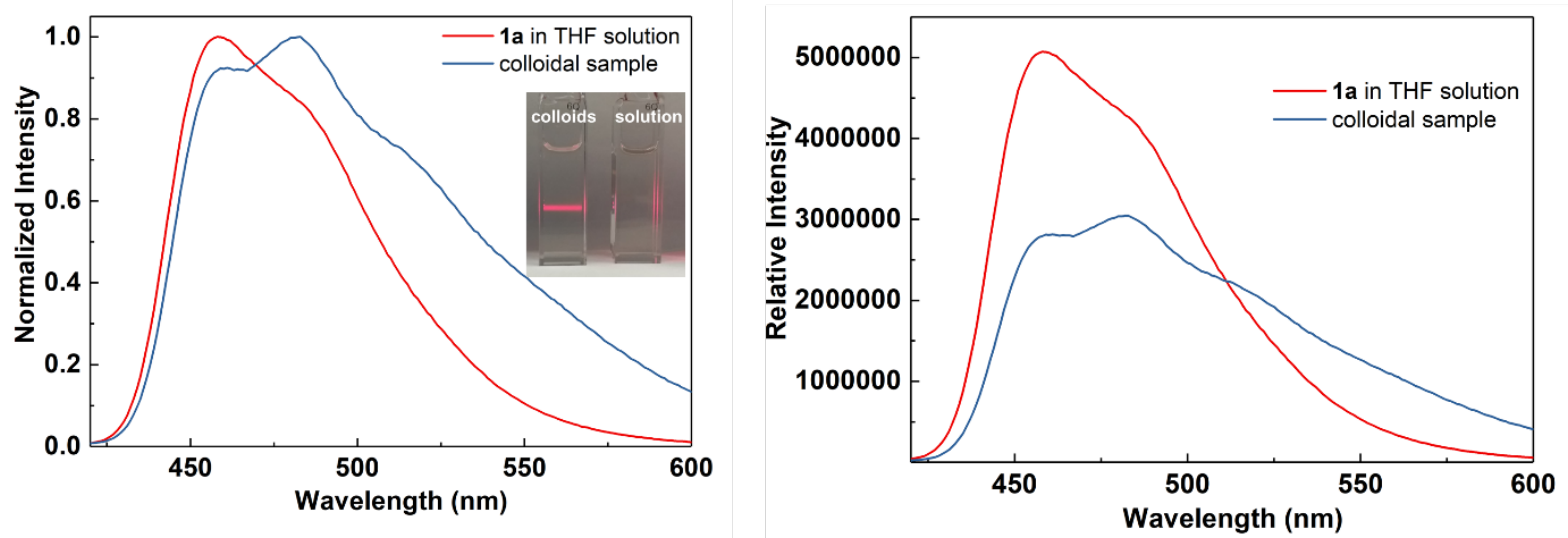

Figure S4. Normalized fluorescence spectra (left) and relative fluorescence intensities (right) of $1 \mathbf{a}(10 \mu \mathrm{M})$ in pure THF and the corresponding colloidal sample at $298 \mathrm{~K}$. Inset: the Tyndall phenomenon observed for the colloids. The colloidal suspension was prepared by dispersing compound 1a in $\mathrm{THF} / \mathrm{H}_{2} \mathrm{O}$ mixture (2/98, $\mathrm{v} / \mathrm{v}$ ). The small red-shift and widening for the emission spectrum with diminished intensity were may be attributed to the increased solvent polarity enhanced by the water and the small tendency to form excitonic complexes.
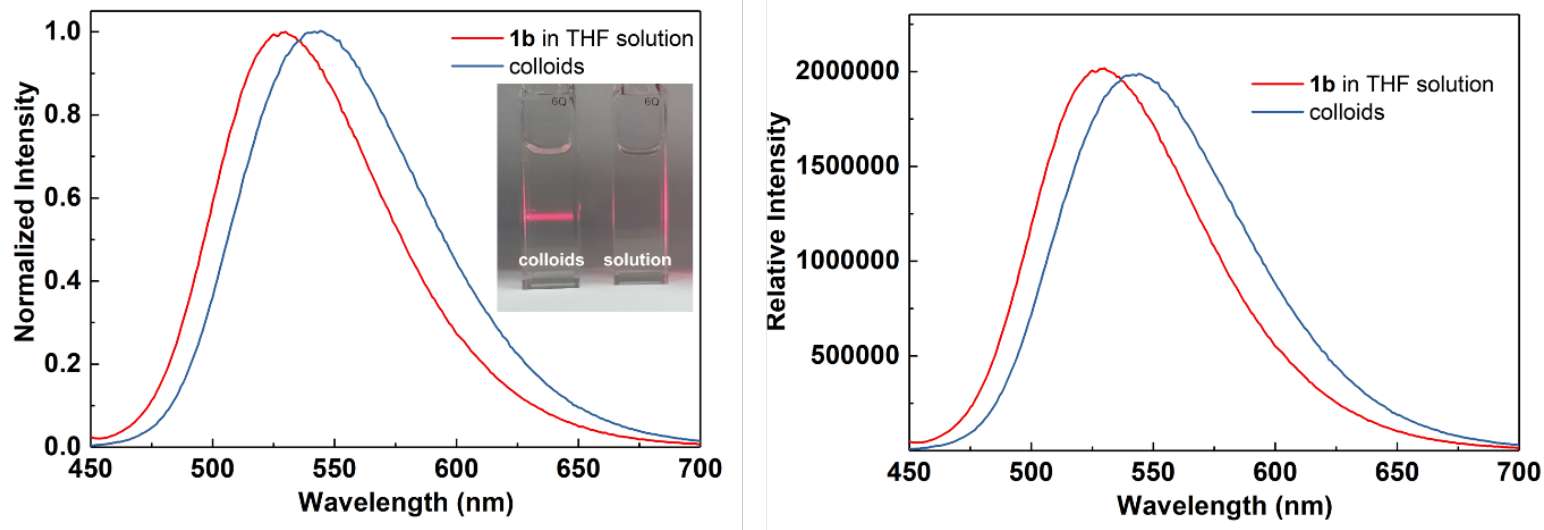

Figure S5. Normalized fluorescence spectra (left) and relative fluorescence intensities (right) of $\mathbf{1 b}(10 \mu \mathrm{M})$ in pure THF and the corresponding colloidal sample at $298 \mathrm{~K}$. Inset: the Tyndall phenomenon observed for the colloids. The colloidal suspension was prepared by dispersing compound $\mathbf{1 b}$ in $\mathrm{THF} / \mathrm{H}_{2} \mathrm{O}$ mixture (2/98, $\mathrm{v} / \mathrm{v}$ ). The small red-shift for the emission maximum were found due to the increased solvent polarity, which is enhanced by the water. 

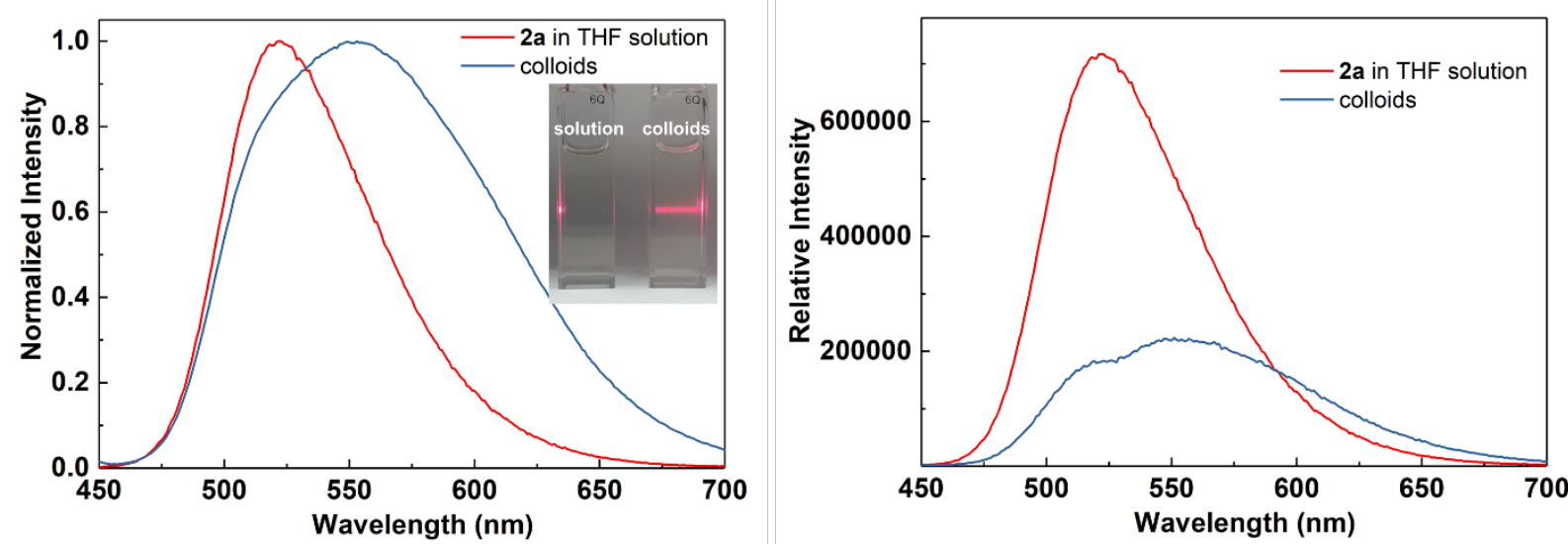

Figure S6. Normalized fluorescence spectra (left) and relative fluorescence intensities (right) of $\mathbf{2 a}(10 \mu \mathrm{M})$ in pure THF and the corresponding colloidal sample at $298 \mathrm{~K}$. Inset: the Tyndall phenomenon observed for the colloids. The colloidal suspension was prepared by dispersing compound 2a in $\mathrm{THF} / \mathrm{H}_{2} \mathrm{O}$ mixture (2/98, $\mathrm{v} / \mathrm{v}$ ). The small red-shift and widening for the emission spectrum accompanying diminished intensity may be attributed to the increased solvent polarity enhanced by water and the small tendency to form excitonic complexes.

(a)

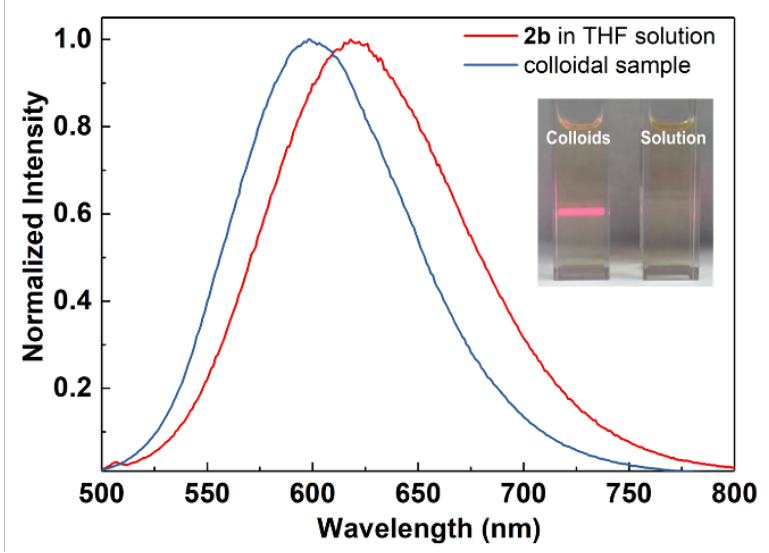

(b)

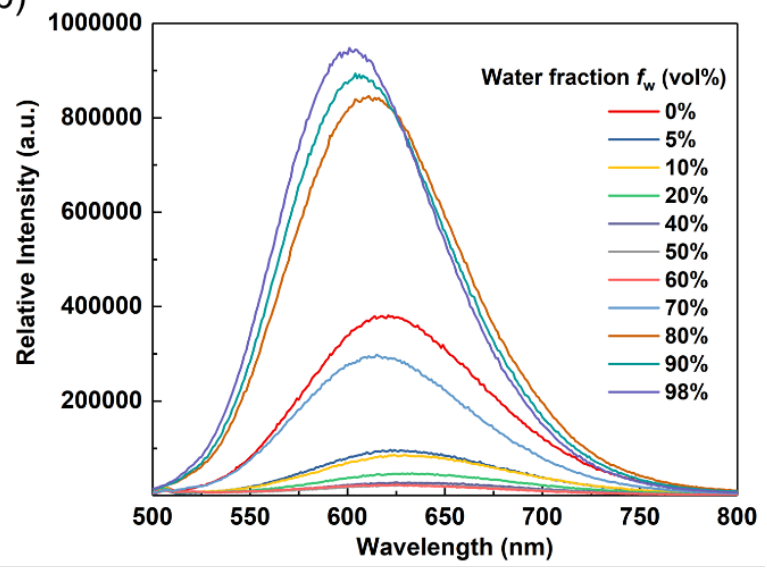

Figure S7. (a) Fluorescence spectra of $\mathbf{2 b}(10 \mu \mathrm{M})$ in pure THF and the corresponding colloidal sample at 298 K. Inset: the Tyndall phenomenon observed for the colloids. The colloidal suspension was prepared by dispersing compound $\mathbf{2 b}$ in $\mathrm{THF} / \mathrm{H}_{2} \mathrm{O}$ mixture $(2 / 98, \mathrm{v} / \mathrm{v})$. (b) Relative fluorescence intensities of $\mathbf{2 b}$ (10 $\mu \mathrm{M})$ in THF/water mixtures with varying water content. Excitation wavelength: $430 \mathrm{~nm}$. 


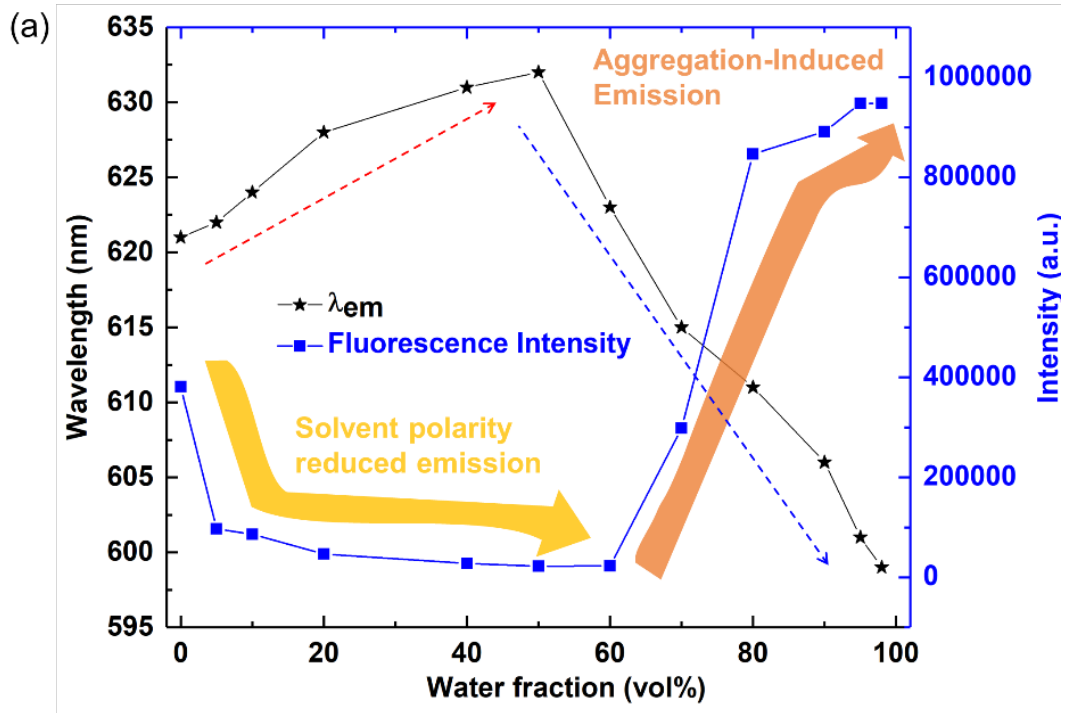

(b)

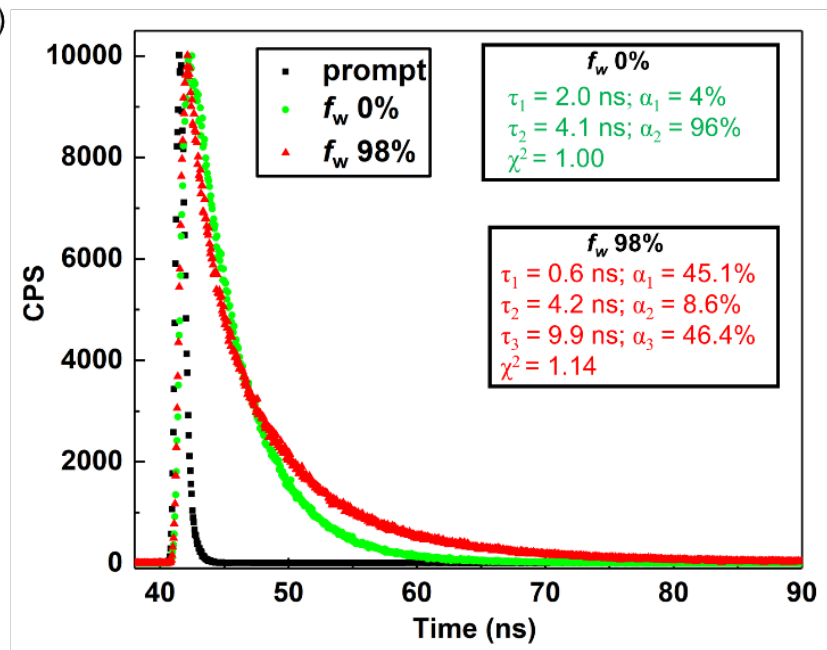

(c)

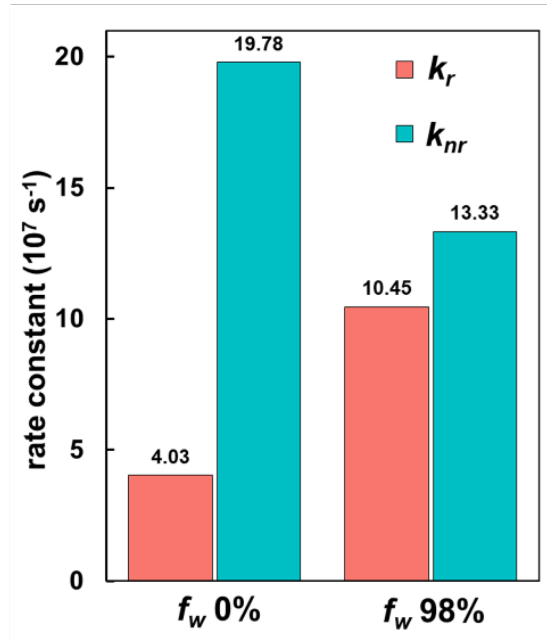

Figure S8. (a) Plots of maximum emission intensity and wavelength $\left(\lambda_{\mathrm{em}}\right)$ of $\mathbf{2 b}(10 \mu \mathrm{M})$ versus varying water fraction $\left(f_{\mathrm{w}}\right)$ in the THF/water mixture. (b) Time-resolved fluorescence decay plots of $\mathbf{2} \mathbf{b}$ in pure THF $\left(f_{\mathrm{w}}=0 \%\right)$ and $98 \%$ water in THF solution $\left(f_{\mathrm{w}}=98 \%\right), \lambda_{\mathrm{ex}}=344 \mathrm{~nm}$. (c) Rate constants of radiative $\left(k_{\mathrm{r}}\right.$, red $)$ and non-radiative decay $\left(k_{n r}\right.$, green) of $\mathbf{2 b}$ in pure THF $\left(f_{\mathrm{w}}=0 \%\right)$ and $98 \%$ water in THF solution $\left(f_{\mathrm{w}}=98 \%\right)$. The small red-shift for the emission maximum and diminished intensity in the first stage were due to the increased solvent polarity, which is enhanced by the water. When the water fraction is up to $60 \%$, the hypsochromic-shift in the emission maximum and enhanced fluorescence intensity were observed. The absolute photoluminescence quantum yield of colloidal sample of $\mathbf{2} \mathbf{b}\left(f_{\mathrm{w}}=98 \%\right)$ was determined to be 0.44 . The restricted intramolecular motion (RIR) of its substituents was realized upon aggregation due to the overcrowded environment within the non-K region of $\mathbf{2} \mathbf{b}$. The blue-shifted emission can be associated with considerable geometrical restrictions in the aggregated state, which lead to smaller distortion of the excited state and hence smaller Stokes shift. 
(a)

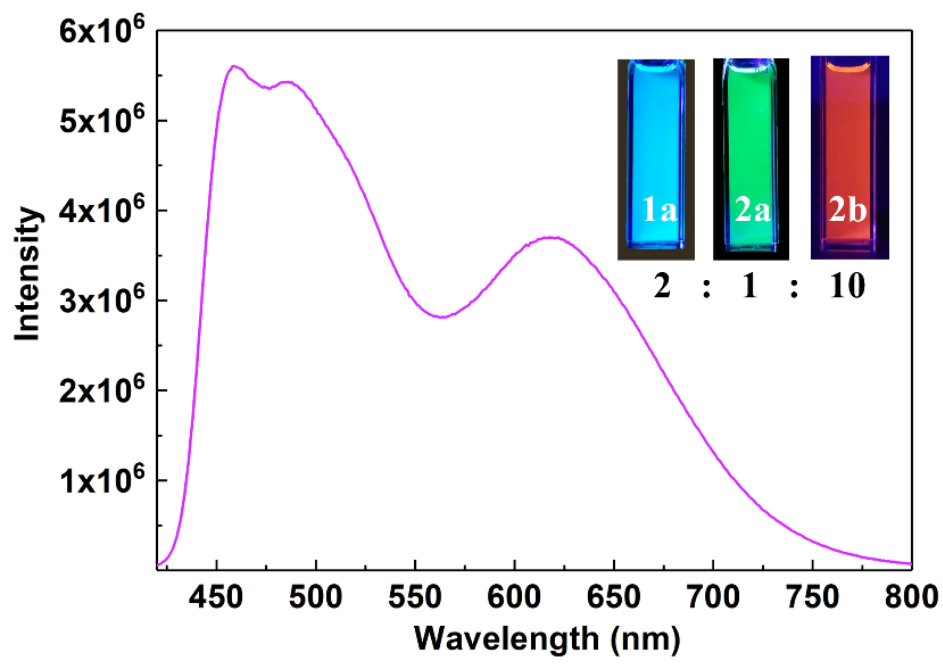

(b)

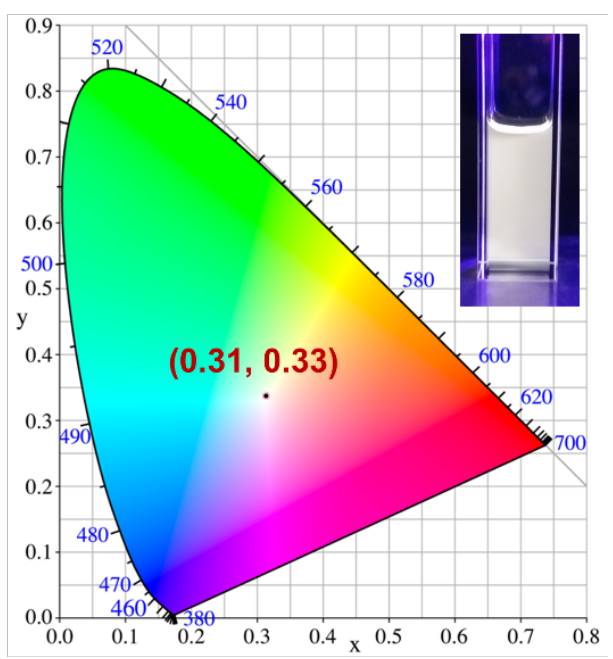

Figure S9. Emission spectrum excited at $430 \mathrm{~nm}$ (a) and its emission color coordinates in the CIE 1931 chromaticity diagram (b) of the solution mixture $(\mathbf{1} \mathbf{a} / \mathbf{2} \mathbf{a} / \mathbf{2} \mathbf{b}, \sim 2 / 1 / 10$, in a screened molar ratio, total concentration: $10 \mu \mathrm{M}$ ) in $\mathrm{CH}_{2} \mathrm{Cl}_{2}$ at $298 \mathrm{~K}$. The pictures were taken under $365 \mathrm{~nm}$ UV light exposure.
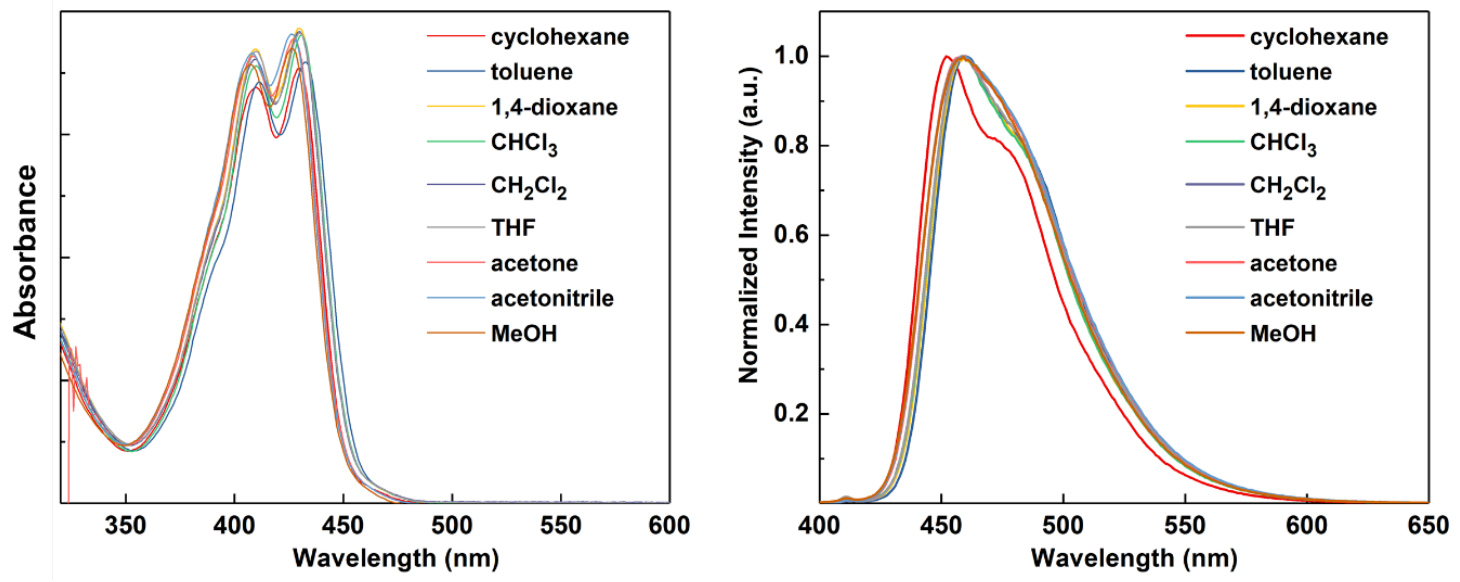

Figure S10. Absorption (left) and fluorescence (right) spectra of 1a in various solvents. 

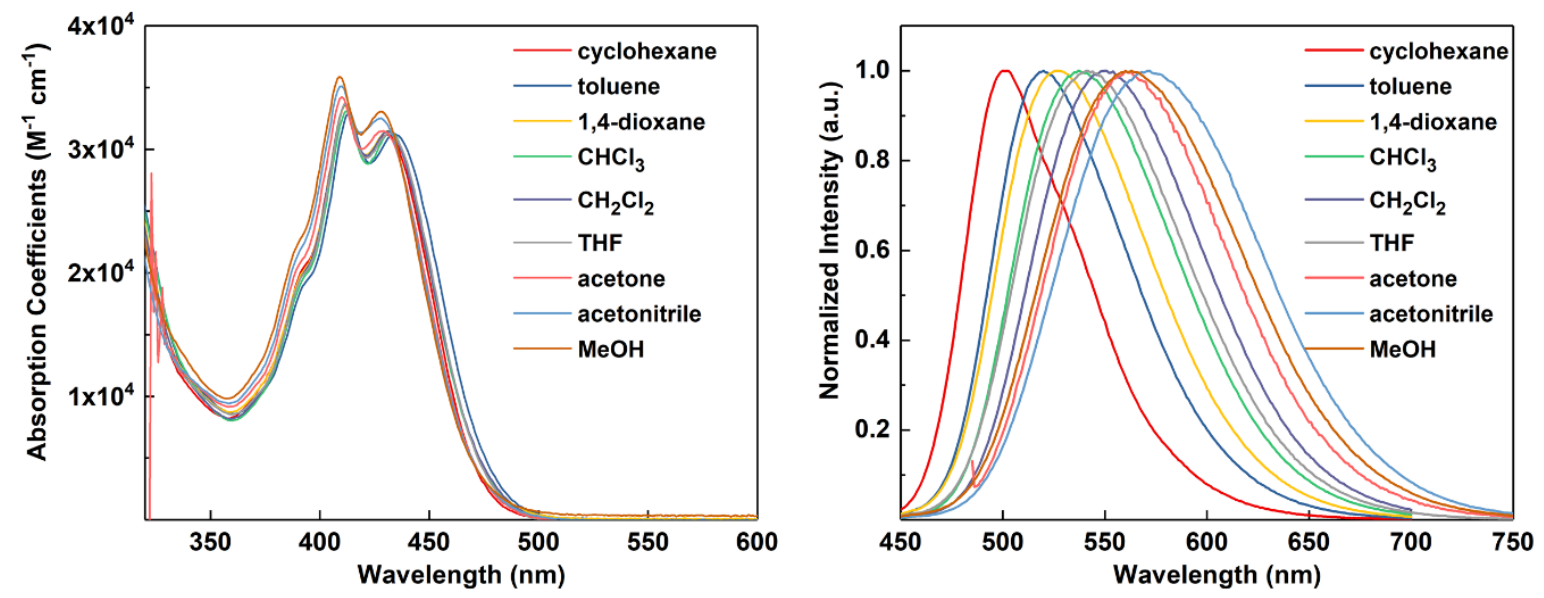

Figure S11. Absorption (left) and fluorescence (right) spectra of $\mathbf{1 b}$ in various solvents.
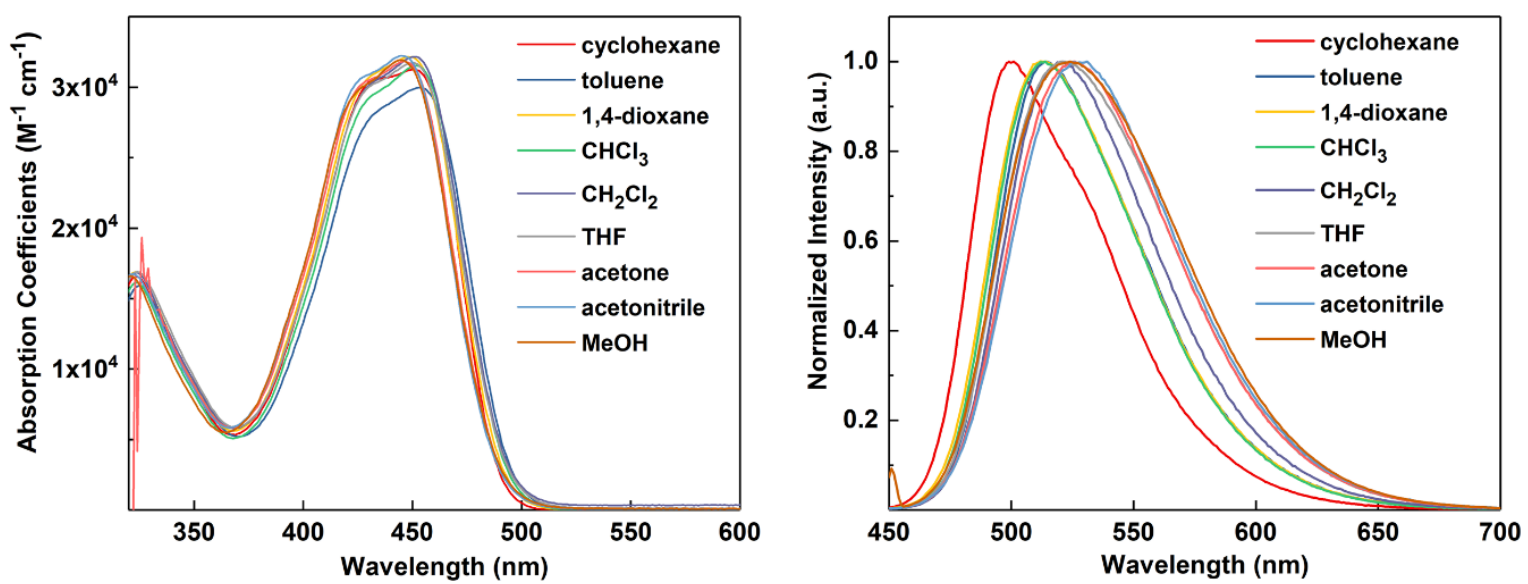

Figure S12. Absorption (left) and fluorescence (right) spectra of $\mathbf{2 a}$ in various solvents.
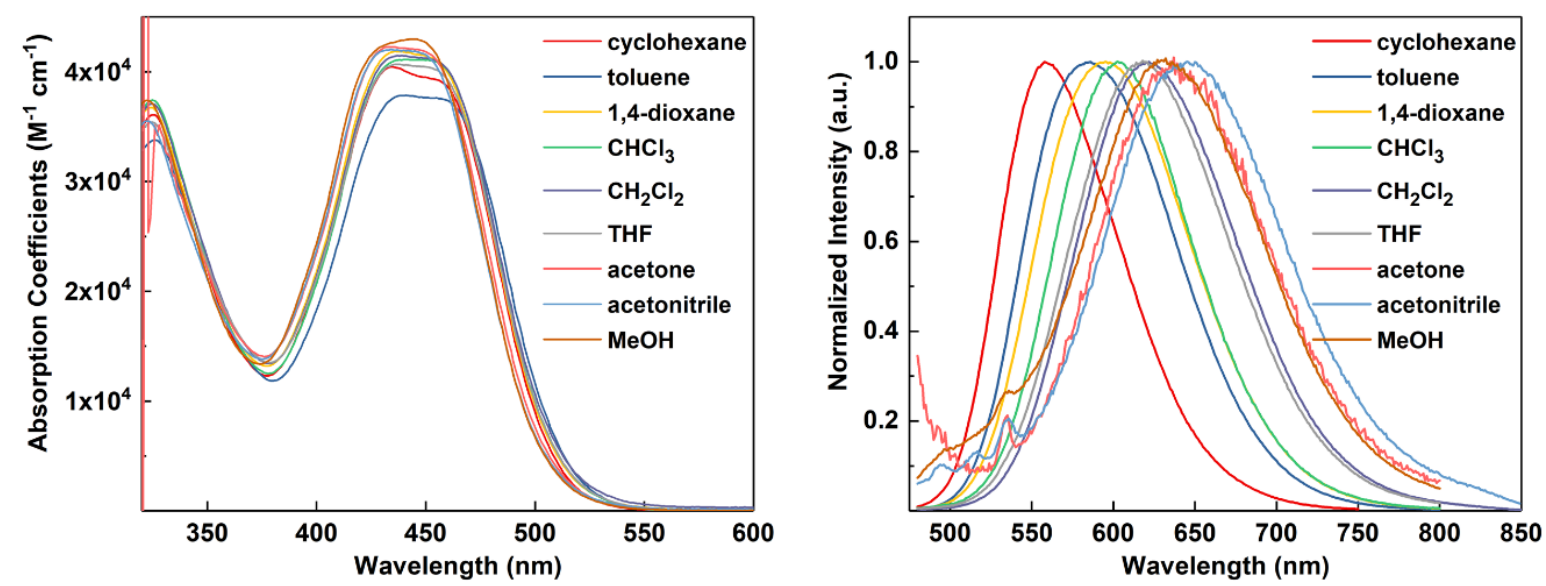

Figure S13. Absorption (left) and fluorescence (right) spectra of $\mathbf{2 b}$ in various solvents. 
Table S1. Photophysical data for compounds $\mathbf{1}$ and $\mathbf{2}$

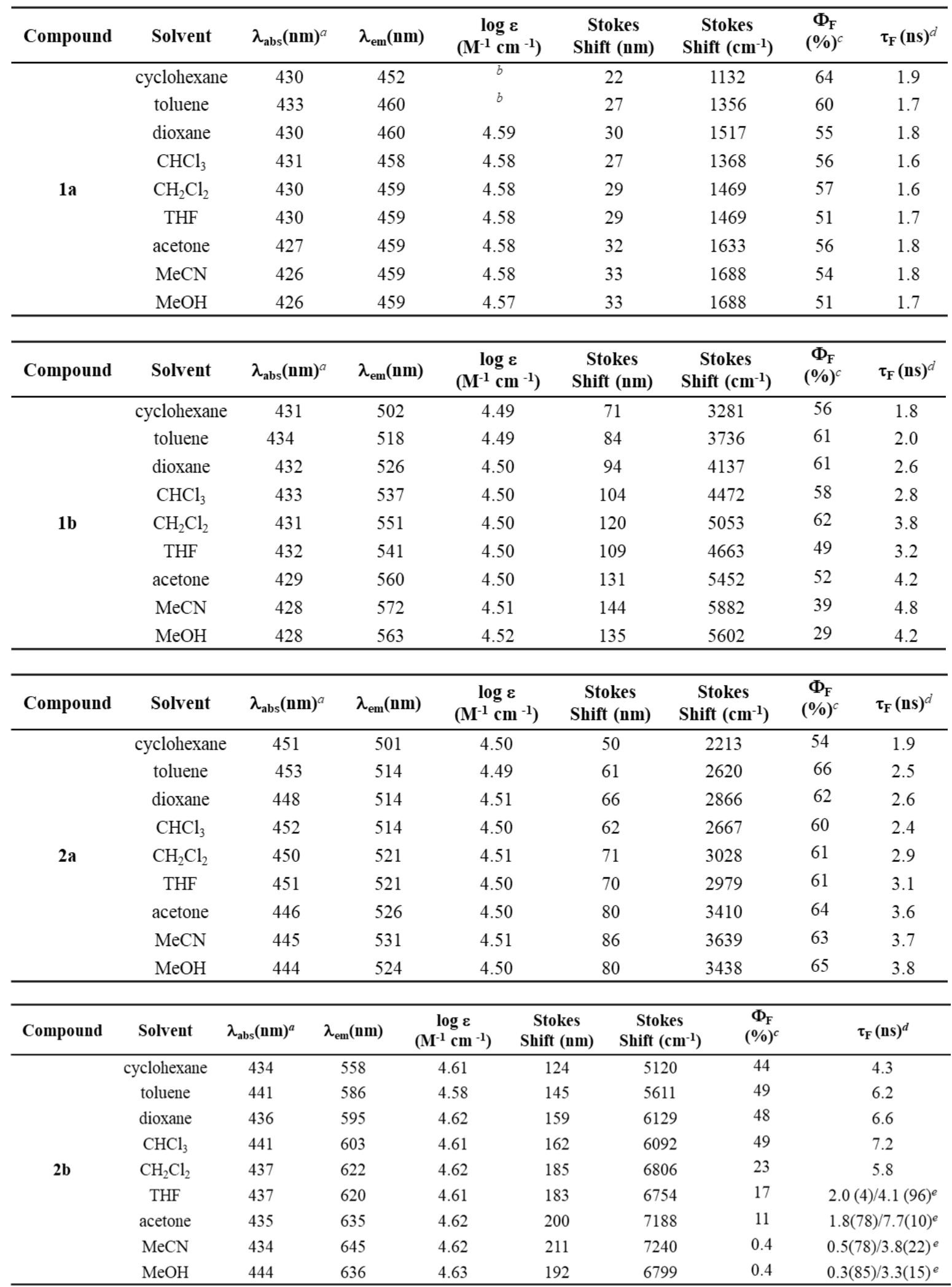


${ }^{a}$ The longest absorption maxima. ${ }^{b}$ Not determined due to the limited solubility. ${ }^{c}$ Relative quantum yields, errors within 5\%. ${ }^{d}$ Fitted with mono-exponential model. ${ }^{e}$ Fitted with bi-exponential model and the amplitudes of two lifetimes given in parentheses.

Table S2. Lippert-Mataga Plot data for $\mathbf{2 b}$

\begin{tabular}{ccccc}
\hline Solvent & $\lambda_{\text {abs }}(\mathrm{nm})$ & $\lambda_{\text {em }}(\mathrm{nm})$ & $\Delta f$ & Stokes Shift $\left(\mathrm{cm}^{-1}\right)$ \\
\hline cyclohexane & 434 & 558 & 0 & 5120 \\
toluene & 441 & 586 & 0.0131 & 5611 \\
$\mathrm{CHCl}_{3}$ & 441 & 603 & 0.01482 & 6092 \\
$\mathrm{CH}_{2} \mathrm{Cl}_{2}$ & 437 & 622 & 0.2171 & 6806 \\
$\mathrm{THF}$ & 437 & 620 & 0.21 & 6754 \\
acetone & 435 & 635 & 0.2843 & 7188 \\
MeCN & 434 & 645 & 0.3086 & 7240 \\
\hline
\end{tabular}

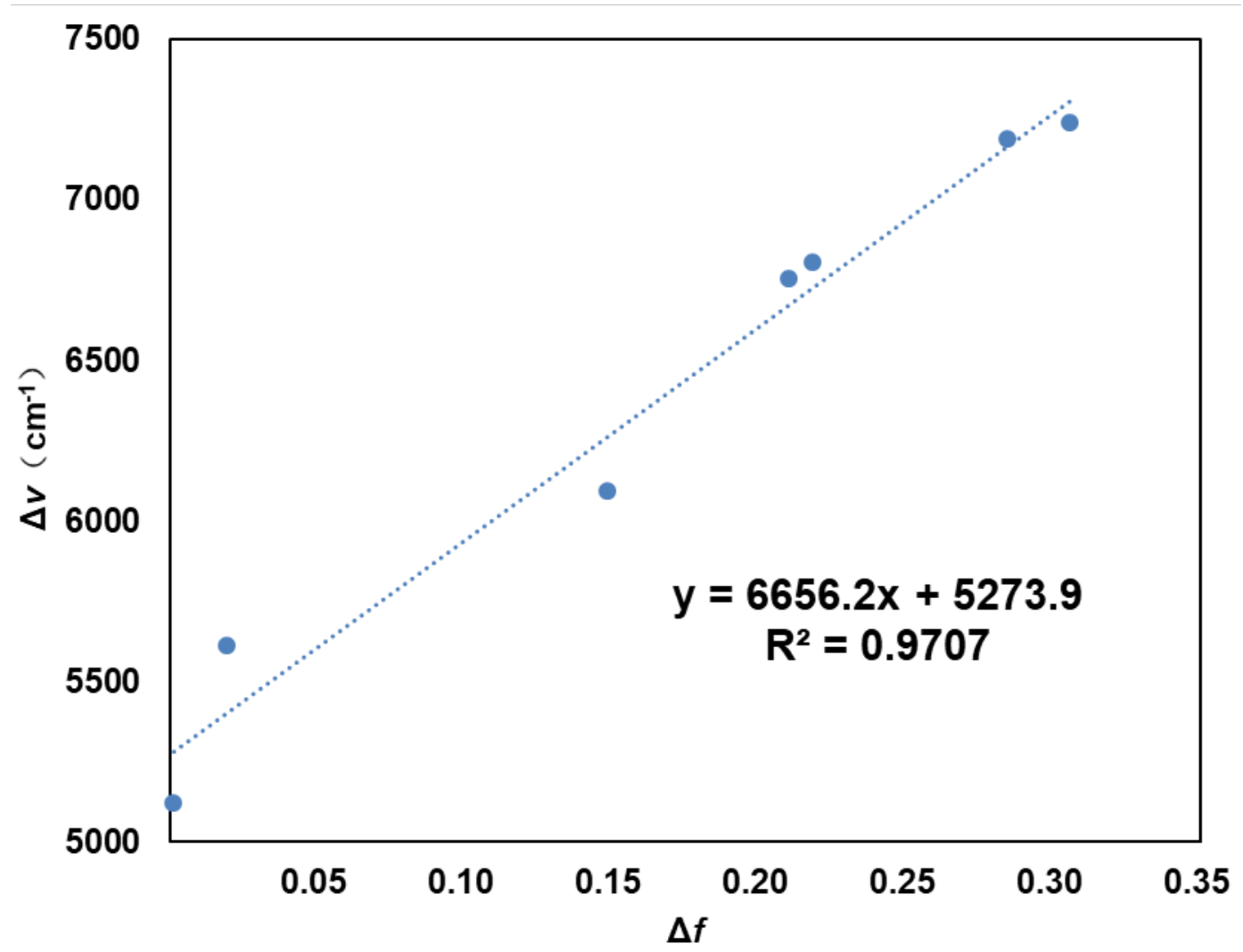

Figure S14. Plot of the Stokes shift $\left(\mathrm{cm}^{-1}, \Delta v\right)$ versus the solvent polarity function $(\Delta f)$ for $\mathbf{2 b}$. 


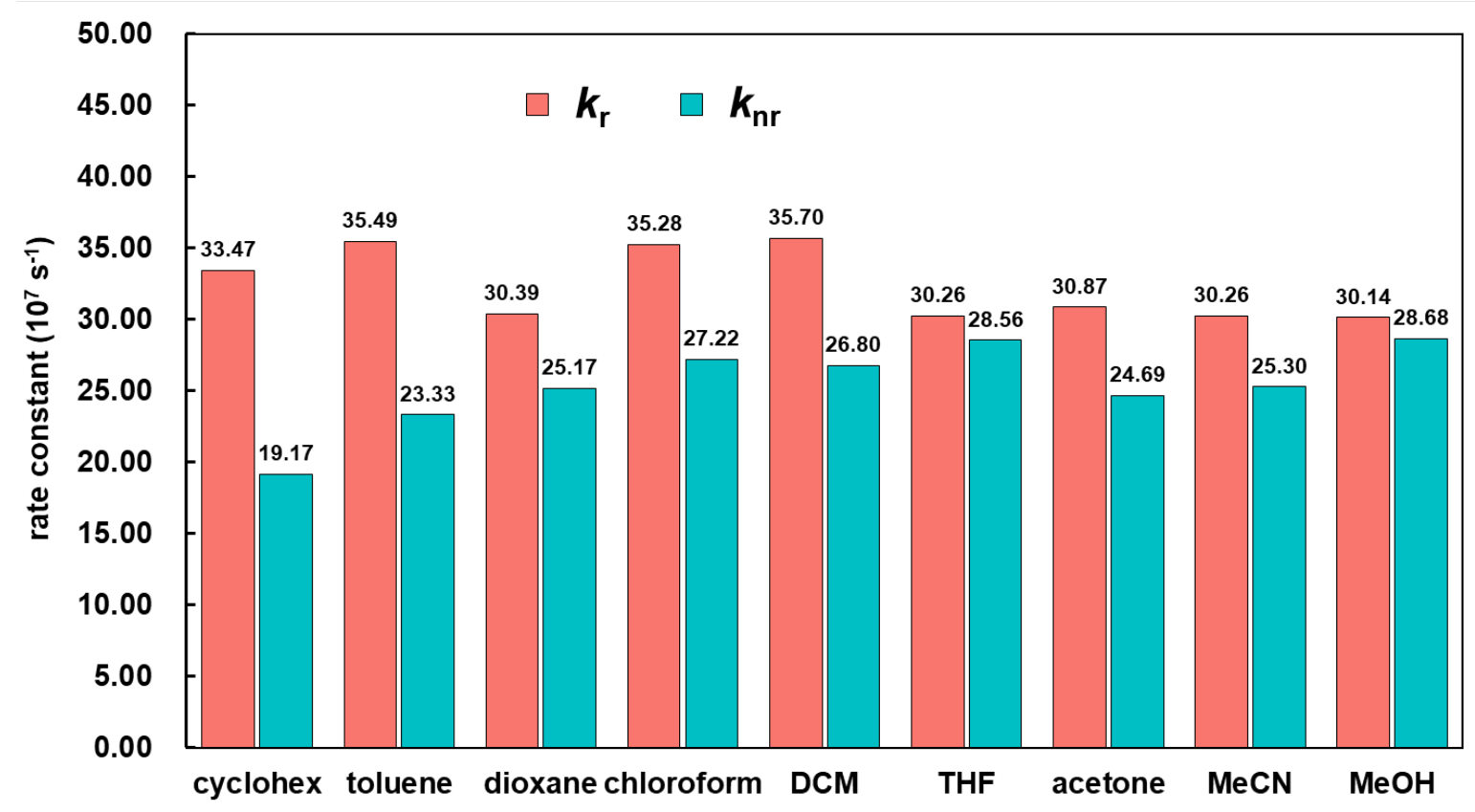

Figure S15. Rate constants of radiative $\left(k_{\mathrm{r}}, \mathrm{red}\right)$ and non-radiative decay $\left(k_{n \mathrm{r}}\right.$, green) of 1a in various solvents.

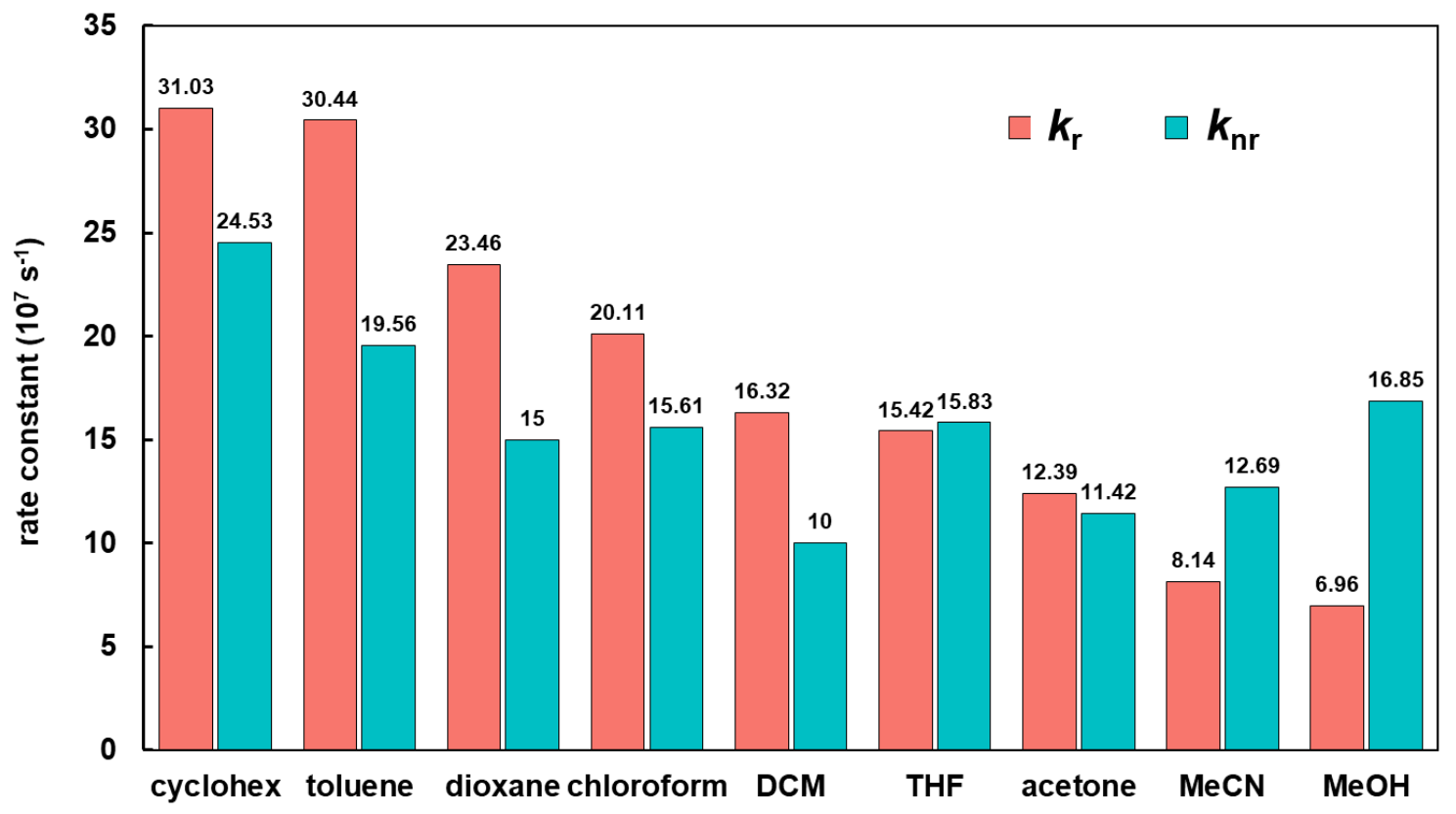

Figure S16. Rate constants of radiative $\left(k_{\mathrm{r}}\right.$, red) and non-radiative decay ( $k_{n}$, green) of $\mathbf{1 b}$ in various solvents. 


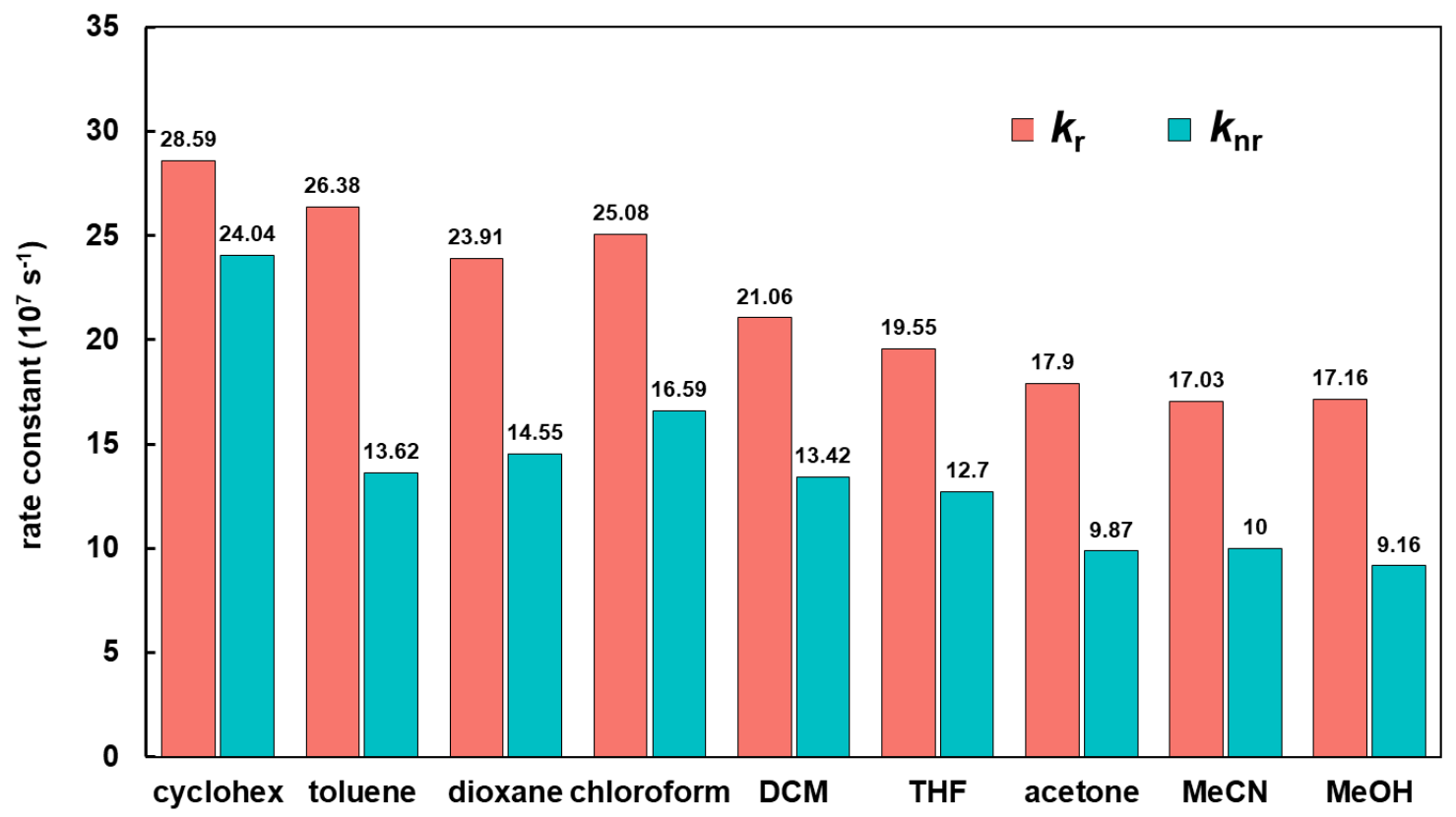

Figure S17. Rate constants of radiative $\left(k_{\mathrm{r}}, \mathrm{red}\right)$ and non-radiative decay ( $k_{n \mathrm{r}}$, green) of 2a in various solvents.

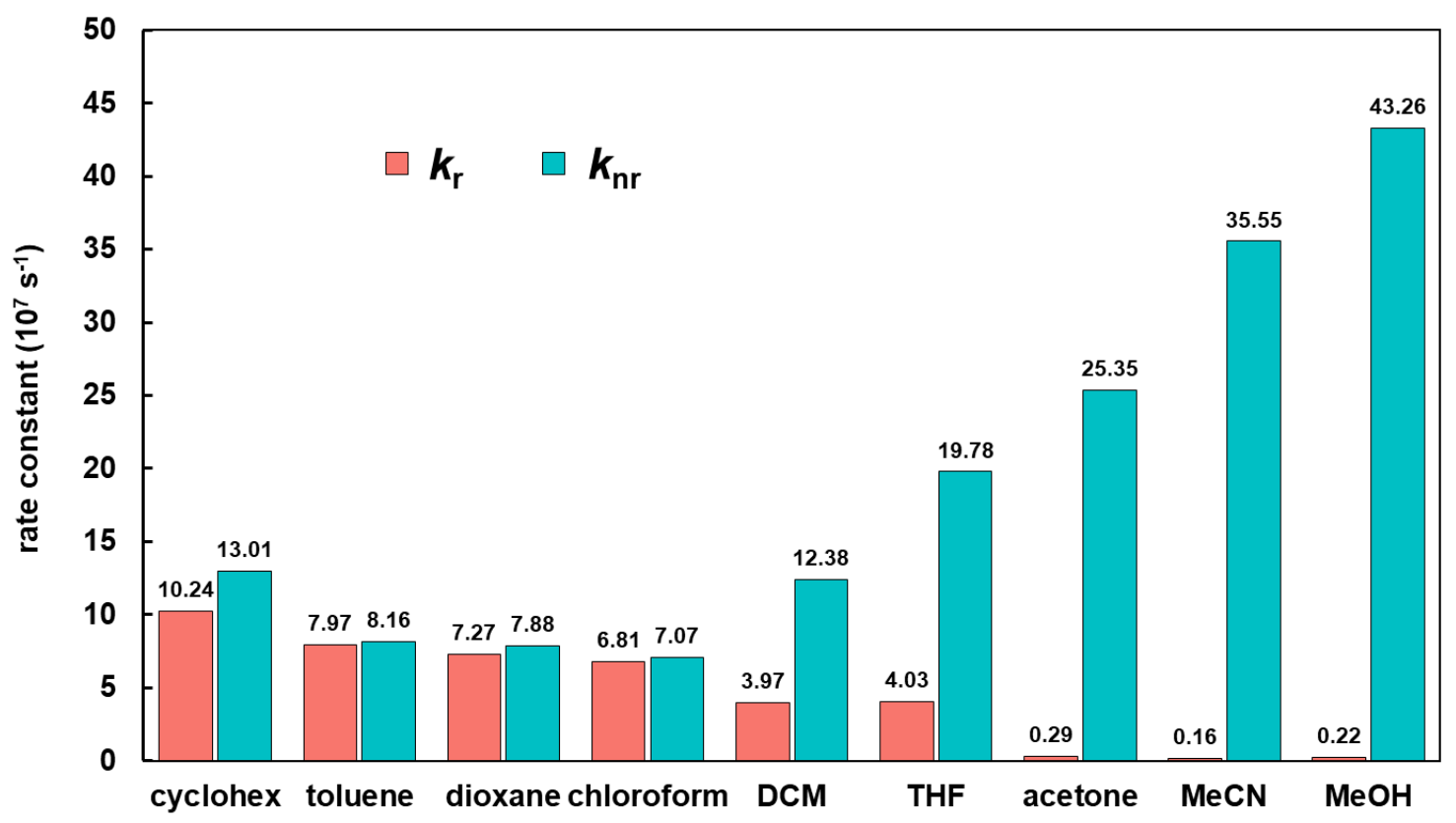

Figure S18. Rate constants of radiative ( $k_{\mathrm{r}}$, red) and non-radiative decay ( $k_{\mathrm{nr}}$, green) of $\mathbf{2 b}$ in various solvents. The abrupt decrease of the quantum yield of $\mathbf{2} \mathbf{b}$ observed in highly polar solvents $(\mathrm{MeCN}, \mathrm{MeOH})$ could be related to the twisted intramolecular charge transfer (TICT)-like excited state, resulting in very small $k_{\mathrm{r}}$. 


\section{Electrochemistry}

All cyclic voltammetry (CV) experiments were conducted using a 3-electrode geometry using a Biologic SP-50 potentiostat. Electrolyte solutions $(0.1 \mathrm{M})$ were prepared from anhydrous, deoxygenated $\mathrm{CH}_{2} \mathrm{Cl}_{2}$ and anhydrous $\mathrm{Bu}_{4} \mathrm{NPF}_{6}$. The working electrode was a glassy carbon electrode (3-mm diameter), with a Pt-coil counter electrode and an Ag wire pseudo reference. Sample concentrations were ca. $1 \mathrm{mM}$. The ferrocene/ferrocenium $\left(\mathrm{Fc} / \mathrm{Fc}^{+}\right)$couple was used as an internal standard following each experiment. Potential values were re-referenced based on the redox potential of $\mathrm{Fc} / \mathrm{Fc}^{+}$being $-4.8 \mathrm{eV}$ vs the vacuum level. ${ }^{10}$ For reversible or quasi-reversible couples, $E_{\mathrm{ox}(\mathrm{red})}=1 / 2\left(E_{\mathrm{pc}}+E_{\mathrm{pa}}\right)$; for irreversible couples, value is estimated as the $E_{\mathrm{pa}}\left(E_{\mathrm{pc}}\right)$ at peak current.

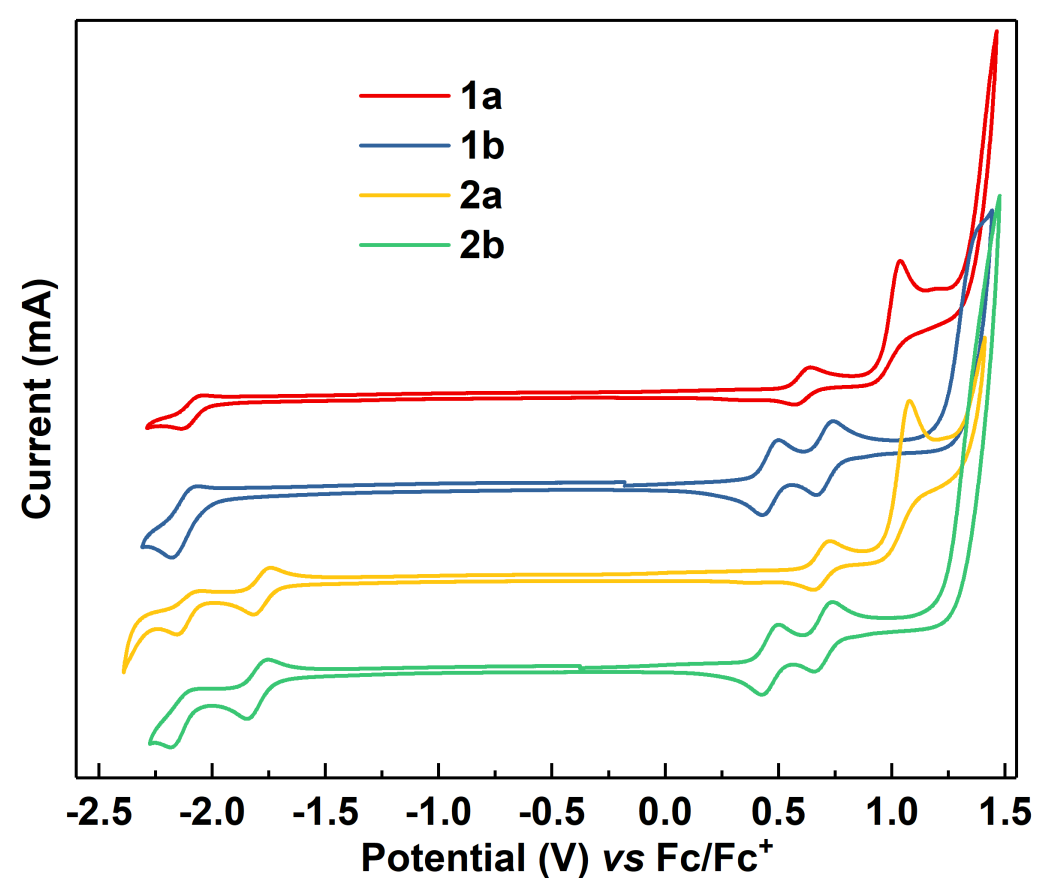

Figure S19. Cyclic voltammograms of 1 and $2\left(0.1 \mathrm{M} \mathrm{Bu}_{4} \mathrm{NPF}_{6}\right.$ in $\mathrm{CH}_{2} \mathrm{Cl}_{2}$, potential $v s \mathrm{Fc} / \mathrm{Fc}^{+}$, scanning rate $v=50 \mathrm{mV} \mathrm{s}^{-1}$ ).

Table S3. Summary of electrochemical data of $\mathbf{1}$ and $\mathbf{2}$

\begin{tabular}{cccccccccc}
\hline Compd & $\begin{array}{c}E_{\text {red }}{ }^{1} \\
(\mathrm{~V})^{a}\end{array}$ & $\begin{array}{c}E_{\text {red }}{ }^{2} \\
(\mathrm{~V})^{a}\end{array}$ & $\begin{array}{c}E_{\text {ox }}{ }^{1} \\
(\mathrm{~V})^{a}\end{array}$ & $\begin{array}{c}E_{\text {ox }}{ }^{2} \\
(\mathrm{~V})^{a}\end{array}$ & $\begin{array}{c}E_{\mathrm{LUMO}} \\
(\mathrm{eV})^{b}\end{array}$ & $\begin{array}{c}E_{\mathrm{HOMO}} \\
(\mathrm{eV})^{b}\end{array}$ & $\begin{array}{c}E_{\mathrm{g}}{ }^{\mathrm{CV}} \\
(\mathrm{eV})^{c}\end{array}$ & $\begin{array}{c}E_{\mathrm{g}}{ }^{\text {opt }} \\
(\mathrm{eV})^{d}\end{array}$ & $\begin{array}{c}E_{g}{ }^{\text {DFT }} \\
(\mathrm{eV})^{e}\end{array}$ \\
\hline $\mathbf{1 a}$ & -2.13 & - & 0.61 & 1.06 & -2.67 & -5.41 & 2.74 & 2.74 & 2.97 \\
$\mathbf{1 b}$ & -2.18 & - & 0.46 & 0.71 & -2.62 & -5.26 & 2.64 & 2.60 & 2.82 \\
$\mathbf{2 a}$ & -1.78 & -2.16 & 0.69 & 1.08 & -3.02 & -5.49 & 2.47 & 2.52 & 2.79 \\
$\mathbf{2 b}$ & -1.79 & -2.18 & 0.46 & 0.70 & -3.01 & -5.26 & 2.25 & 2.35 & 2.58 \\
\hline
\end{tabular}

${ }^{a}$ Potential vs $\mathrm{Fc} / \mathrm{Fc}^{+} .{ }^{b} E_{\mathrm{HOMO} / \mathrm{Lumo}}=-\left(E_{\mathrm{ox} / \mathrm{red}}+4.8 \mathrm{eV}\right) .{ }^{c} E_{g}{ }^{\mathrm{CV}}=E_{\mathrm{HOMO}}-E_{\mathrm{LumO}}{ }^{d} E_{\mathrm{g}}{ }^{\text {opt }}=1240 / \lambda_{\text {onset. }}$. ${ }^{e}$ Determined by the DFT calculations (B3LYP/6-311G**). 


\section{Theoretical Calculations}

The initial structures were generated from the X-ray crystallography data for 1a. Other similar structures are adjusted according to the structures in the single crystal. These initial structures were optimized using the functional B3LYP and 6-311G(d,p) basis set as implemented in Gaussian 09. ${ }^{11}$ In addition, all the optimized structures were confirmed by frequency analysis and the number of imaginary frequencies was zero. Initially, TD-DFT vertical excitation calculations were performed using the long-range-corrected CAM-B3LYP (which is reported are necessary to obtain a reliable energy ordering in the excited states of pyrene itself, it is composed of $19 \% \mathrm{HF}$ exchange at short-range and $65 \%$ HF exchange at long-range $)^{12}$ and B3LYP (20\% HF exchange) theory with the unified $6-311+\mathrm{G}(\mathrm{d}, \mathrm{p})$ basis set. We found that the former DFT method qualitatively reproduce the experimentally obtained absorption characteristics (possible vibrational progression on the $\mathrm{PN}$-heterocyclic pyrene core may mix with the absorption band, like ca. $2320 \mathrm{~cm}^{-1}$ in $\mathbf{1}$, ca. $2220 \mathrm{~cm}^{-1}$ in $\mathbf{2}$, since the intensities for these two peaks are diminished as the ICT effect and structural/conformational flexibility increase), while the latter gave significantly red-shifted electronic transition energies with respect to the experimental values (Tables S4-S5). Nevertheless, all the methods assign the lowest energy absorption bands to the ground state $\left(\mathrm{S}_{0}\right)$ $\rightarrow$ the first excited state $\left(S_{1}\right)$ electronic transitions with the largest oscillator strength, which are dominated by the transitions from HOMO to LUMO. The geometry optimization of $\mathrm{S}_{1}$ for $\mathbf{2} \mathbf{b}$ were carried out at TD-B3LYP/6-311G(d,p) level of theory. The PCM solvation model ${ }^{13}$ was used to account for the solvent effects of the $\mathrm{CH}_{2} \mathrm{Cl}_{2}$. Orbital composition analysis with Ros-Schuit (Csquared Population Analysis, SCPA) method and Mayer bond order analysis using Multiwfn software. ${ }^{14}$
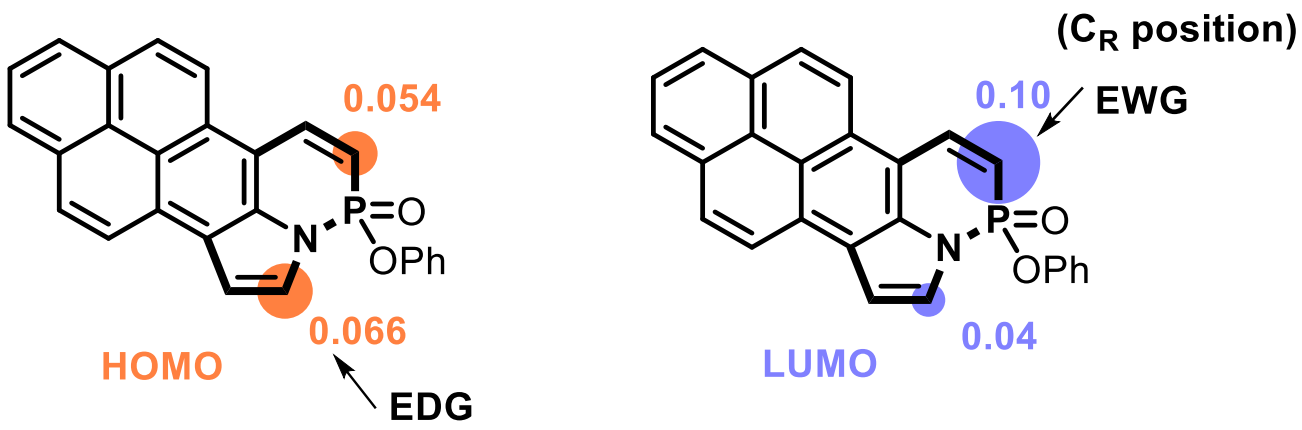

( Ar $_{\text {Ar }}$ position) 
Figure S20. Atomic contributions to HOMO (left) and LUMO (right) electron densities for the parent core. The orange/blue circle diameter represents the atomic contribution, calculated at the B3LYP/6-311G(d,p) level of theory. Only functionalizable positions are shown.

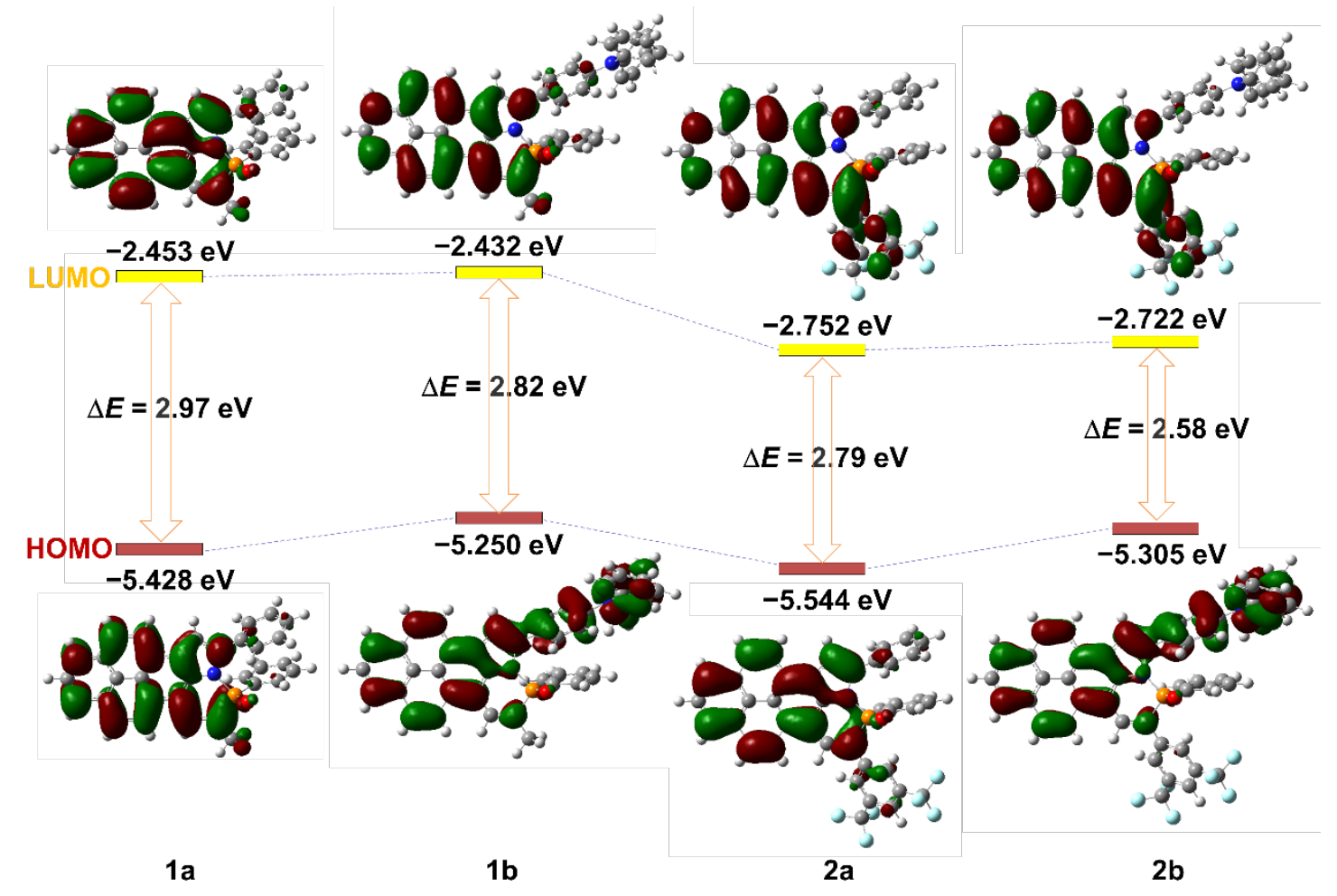

Figure S21. Molecular orbital diagram for 1 and 2, calculated at the B3LYP/6-311G(d,p) level of theory.

Table S4 Selected wavelength, oscillator strength $(f)$ and major configuration calculated at the $\operatorname{PCM}\left(\mathrm{CH}_{2} \mathrm{Cl}_{2}\right)$-TD-CAM-B3LYP/6-311+G(d,p) level of theory.

\begin{tabular}{|c|c|c|c|c|}
\hline & $\lambda_{\text {cal }}(\mathrm{nm})$ & $\begin{array}{l}\text { electronic } \\
\text { transitions }\end{array}$ & $f$ & Major configurations \\
\hline \multirow{4}{*}{$1 \mathbf{a}$} & 404 & $\mathrm{~S}_{1} \leftarrow \mathrm{S}_{0}$ & 1.2408 & $\mathrm{HOMO} \rightarrow$ LUMO $(97 \%)$ \\
\hline & 348 & $\mathrm{~S}_{2} \leftarrow \mathrm{S}_{0}$ & 0.083 & $\begin{array}{l}\mathrm{HOMO}-1 \rightarrow \mathrm{LUMO}(76 \%) \\
\mathrm{HOMO} \rightarrow \mathrm{LUMO}+2(8 \%), \\
\mathrm{HOMO} \rightarrow \mathrm{LUMO}+3(6 \%)\end{array}$ \\
\hline & 293 & $\mathrm{~S}_{3} \leftarrow \mathrm{S}_{0}$ & 0.2946 & $\begin{array}{l}\mathrm{HOMO}-2 \rightarrow \mathrm{LUMO}(10 \%), \\
\mathrm{HOMO} \rightarrow \mathrm{LUMO}+1(23 \%), \\
\mathrm{HOMO} \rightarrow \mathrm{LUMO}+3(41 \%)\end{array}$ \\
\hline & 267 & $\mathrm{~S}_{6} \leftarrow \mathrm{S}_{0}$ & 0.2078 & $\begin{array}{l}\mathrm{HOMO}-2 \rightarrow \text { LUMO }(31 \%), \\
\mathrm{HOMO} \rightarrow \text { LUMO+1 }(12 \%), \\
\mathrm{HOMO} \rightarrow \text { LUMO+3 }(25 \%), \\
\mathrm{HOMO} \rightarrow \mathrm{LUMO}+4(13 \%)\end{array}$ \\
\hline
\end{tabular}




\begin{tabular}{|c|c|c|c|c|}
\hline \multirow{4}{*}{$1 b$} & 409 & $\mathrm{~S}_{1} \leftarrow \mathrm{S}_{0}$ & 1.4206 & $\begin{array}{c}\text { HOMO- } 1 \rightarrow \text { LUMO }(10 \%) \\
\text { HOMO } \rightarrow \text { LUMO }(86 \%)\end{array}$ \\
\hline & 353 & $\mathrm{~S}_{2} \leftarrow \mathrm{S}_{0}$ & 0.1745 & $\begin{array}{l}\text { HOMO-2 } \rightarrow \text { LUMO }(55 \%), \\
\text { HOMO- } 1 \rightarrow \text { LUMO }(24 \%)\end{array}$ \\
\hline & 322 & $\mathrm{~S}_{3} \leftarrow \mathrm{S}_{0}$ & 0.2814 & $\begin{array}{c}\text { HOMO-2 } \rightarrow \text { LUMO }(11 \%), \\
\text { HOMO- } 1 \rightarrow \text { LUMO }(31 \%), \\
\text { HOMO- } 1 \rightarrow \text { LUMO+2 }(10 \%), \\
\text { HOMO } \rightarrow \text { LUMO+2 }(12 \%), \\
\text { HOMO } \rightarrow \text { LUMO+3 }(12 \%)\end{array}$ \\
\hline & & & ... & \\
\hline \multirow{4}{*}{$2 a$} & 428 & $\mathrm{~S}_{1} \leftarrow \mathrm{S}_{0}$ & 1.2669 & HOMO $\rightarrow$ LUMO $(96 \%)$ \\
\hline & 359 & $\mathrm{~S}_{2} \leftarrow \mathrm{S}_{0}$ & 0.1585 & HOMO-1 $\rightarrow$ LUMO (82\%) \\
\hline & 307 & $\mathrm{~S}_{3} \leftarrow \mathrm{S}_{0}$ & 0.3472 & $\begin{array}{l}\text { HOMO-2 } \rightarrow \text { LUMO }(10 \%) \\
\text { HOMO } \rightarrow \text { LUMO+2 }(52 \%)\end{array}$ \\
\hline & & & $\cdots$ & \\
\hline \multirow{5}{*}{$2 \mathbf{b}$} & 433 & $\mathrm{~S}_{1} \leftarrow \mathrm{S}_{0}$ & 1.3541 & $\begin{aligned} \text { HOMO- } 1 & \rightarrow \text { LUMO }(18 \%) \\
\text { HOMO } & \rightarrow \text { LUMO }(78 \%)\end{aligned}$ \\
\hline & 367 & $\mathrm{~S}_{2} \leftarrow \mathrm{S}_{0}$ & 0.3022 & $\begin{array}{l}\text { HOMO-2 } \rightarrow \text { LUMO }(54 \%) \\
\text { HOMO-1 } \rightarrow \text { LUMO }(27 \%)\end{array}$ \\
\hline & 331 & $\mathrm{~S}_{3} \leftarrow \mathrm{S}_{0}$ & 0.1888 & $\begin{array}{l}\text { HOMO-2 } \rightarrow \text { LUMO }(19 \%), \\
\text { HOMO- } 1 \rightarrow \text { LUMO }(28 \%), \\
\text { HOMO } \rightarrow \text { LUMO }+5(13 \%)\end{array}$ \\
\hline & 307 & $\mathrm{~S}_{4} \leftarrow \mathrm{S}_{0}$ & 0.3803 & $\begin{array}{l}\text { HOMO- } 1 \rightarrow \text { LUMO }(11 \%) \\
\text { HOMO } \rightarrow \text { LUMO+2 }(41 \%)\end{array}$ \\
\hline & & & $\cdots$ & \\
\hline
\end{tabular}

Table S5 Selected wavelength, oscillator strength $(f)$ and major configuration calculated at the $\operatorname{PCM}\left(\mathrm{CH}_{2} \mathrm{Cl}_{2}\right)-\mathrm{TD}-\mathrm{B} 3 \mathrm{LYP} / 6-311+\mathrm{G}(\mathrm{d}, \mathrm{p})$ level of theory.

\begin{tabular}{|c|c|c|c|c|}
\hline & $\lambda_{\text {cal }}(\mathrm{nm})$ & $\begin{array}{l}\text { electronic } \\
\text { transitions }\end{array}$ & $f$ & Major configurations \\
\hline \multirow{5}{*}{$1 \mathbf{a}$} & 452 & $\mathrm{~S}_{1} \leftarrow \mathrm{S}_{0}$ & 0.9763 & $\mathrm{HOMO} \rightarrow$ LUMO (97\%) \\
\hline & 381 & $\mathrm{~S}_{2} \leftarrow \mathrm{S}_{0}$ & 0.0913 & $\begin{array}{c}\text { HOMO-1 } \rightarrow \text { LUMO }(84 \%), \\
\text { HOMO } \rightarrow \text { LUMO+3 }(7 \%)\end{array}$ \\
\hline & 351 & $\mathrm{~S}_{3} \leftarrow \mathrm{S}_{0}$ & 0.0574 & $\mathrm{HOMO} \rightarrow \mathrm{LUMO}+1(93 \%)$ \\
\hline & 311 & $\mathrm{~S}_{7} \leftarrow \mathrm{S}_{0}$ & 0.1868 & $\begin{array}{l}\text { HOMO-2 } \rightarrow \text { LUMO }(18 \%), \\
\text { HOMO } \rightarrow \text { LUMO }+3(55 \%)\end{array}$ \\
\hline & & & ... & \\
\hline \multirow{2}{*}{$1 b$} & 495 & $\mathrm{~S}_{1} \leftarrow \mathrm{S}_{0}$ & 0.6918 & HOMO $\rightarrow$ LUMO $(96 \%)$ \\
\hline & 429 & $\mathrm{~S}_{2} \leftarrow \mathrm{S}_{0}$ & 0.4885 & HOMO-1 $\rightarrow$ LUMO $(95 \%)$ \\
\hline
\end{tabular}




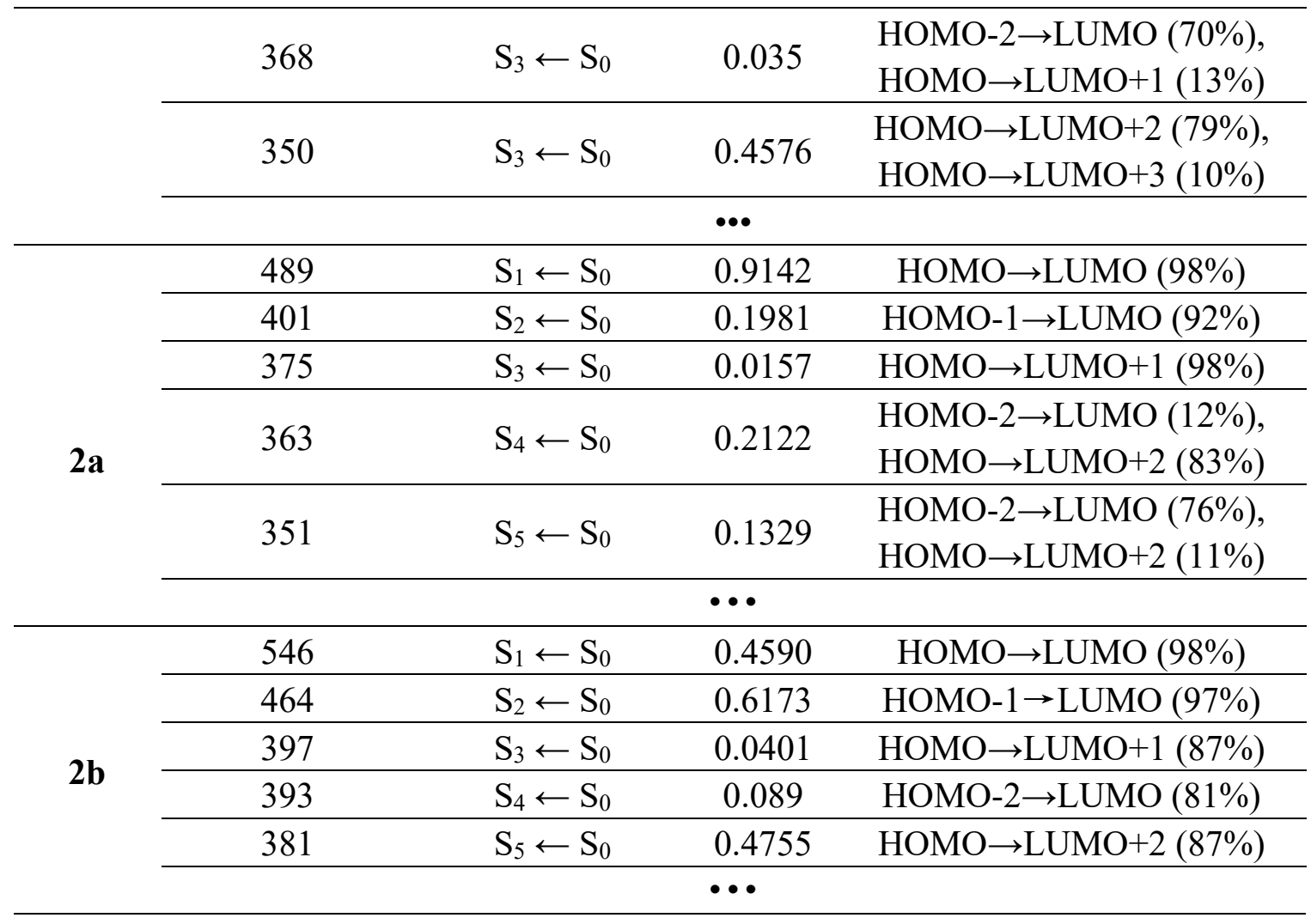

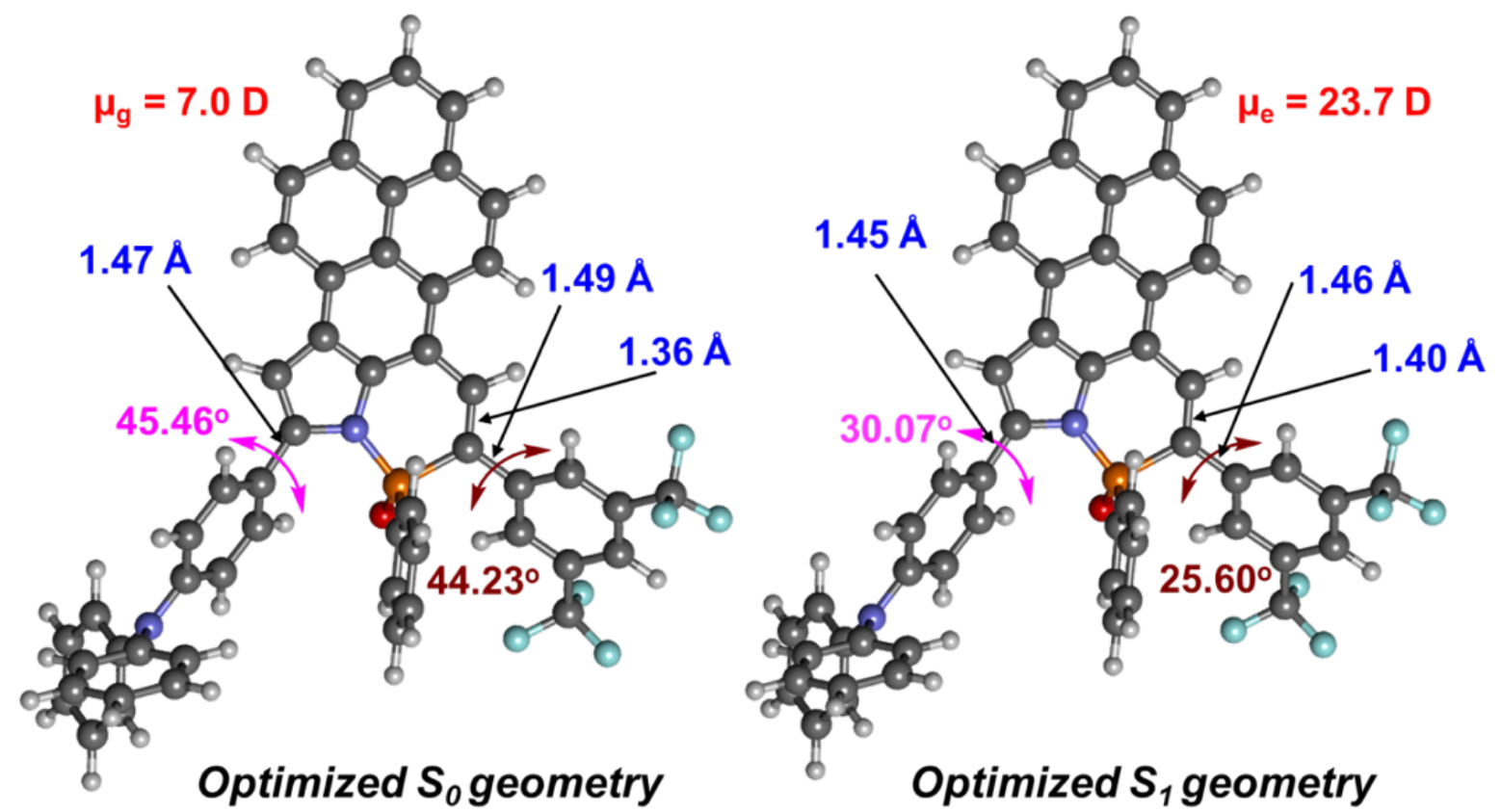

Figure S22. Selected bond lengths $(\AA)$ and dihedral angles $\left(^{\circ}\right)$ in the optimized $S_{0}$ and $S_{1}$ structures of $\mathbf{2 b}$ calculated by the DFT and TD-DFT methods at the PCM(DCM)-B3LYP/6-311G(d,p) levels of theory, respectively. 


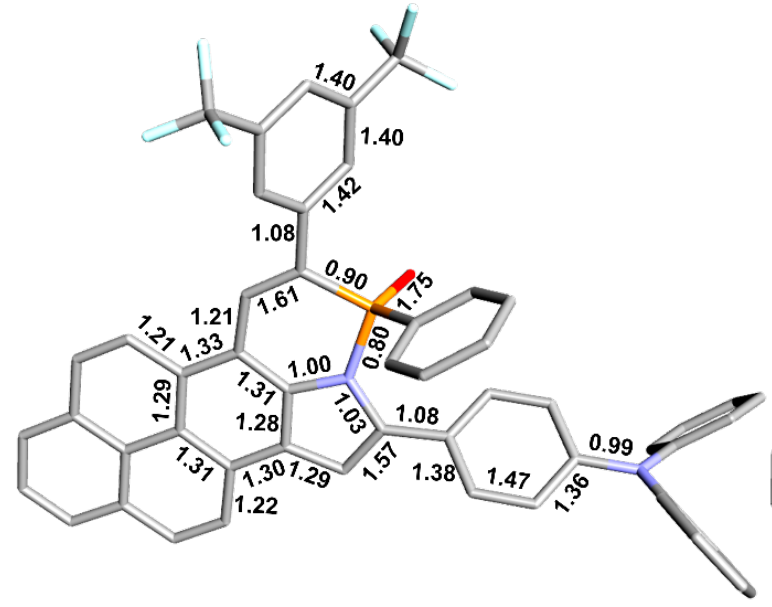

Optimized $S_{0}$ geometry

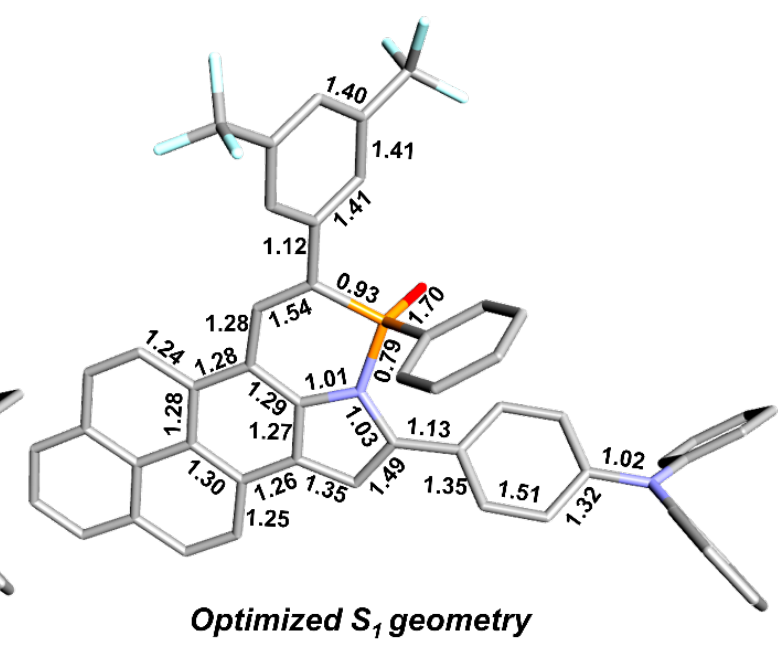

Optimized $S_{1}$ geometry

Figure S23. Selected Mayer bond indices in the optimized $\mathrm{S}_{0}$ and $\mathrm{S}_{1}$ structures of $\mathbf{2 b}$ calculated by the DFT and TD-DFT methods at the PCM(DCM)-B3LYP/6-311G(d,p) levels of theory, respectively.
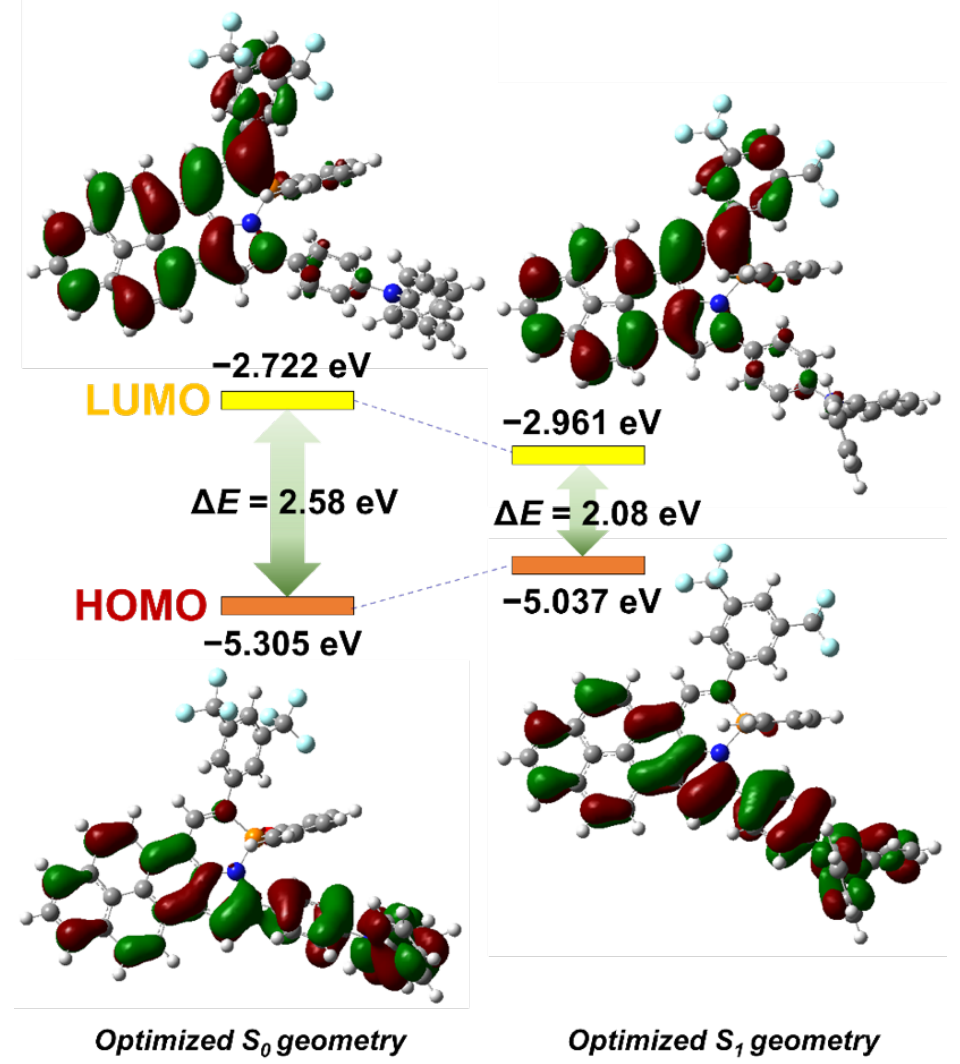

Figure S24. HOMO-LUMO energies and their differences $(\Delta E)$ in the optimized $\mathrm{S}_{0}$ and $\mathrm{S}_{1}$ structures of $\mathbf{2 b}$ calculated by the DFT and TD-DFT methods at the PCM(DCM)-B3LYP/6-311G(d,p) levels of theory, respectively. 
Table S6. Cartesian coordinates for compound 1a.

\begin{tabular}{|c|c|c|c|}
\hline & $X$ & Y & $\mathrm{Z}$ \\
\hline $\mathrm{P}$ & 1.07271 & 1.85190 & -0.84132 \\
\hline $\mathrm{O}$ & 1.75912 & 1.86337 & -2.17463 \\
\hline $\mathrm{N}$ & 0.29059 & 0.36049 & -0.43130 \\
\hline $\mathrm{C}$ & -0.30069 & 3.01724 & -0.72302 \\
\hline $\mathrm{C}$ & -1.58764 & 2.62532 & -0.59726 \\
\hline $\mathrm{C}$ & -2.04300 & 1.26294 & -0.42146 \\
\hline $\mathrm{C}$ & -1.09627 & 0.23466 & -0.33634 \\
\hline $\mathrm{C}$ & -1.41167 & -1.10931 & -0.07226 \\
\hline $\mathrm{C}$ & -0.17112 & -1.81462 & 0.00260 \\
\hline $\mathrm{C}$ & 0.85022 & -0.92824 & -0.22115 \\
\hline $\mathrm{C}$ & -2.76335 & -1.49432 & 0.07082 \\
\hline $\mathrm{C}$ & -3.76302 & -0.48264 & -0.04944 \\
\hline $\mathrm{C}$ & -3.40905 & 0.89212 & -0.29020 \\
\hline $\mathrm{C}$ & -4.47584 & 1.84858 & -0.39276 \\
\hline $\mathrm{C}$ & -5.78125 & 1.49078 & -0.26972 \\
\hline $\mathrm{C}$ & -6.16574 & 0.13237 & -0.02543 \\
\hline $\mathrm{C}$ & -5.13875 & -0.85136 & 0.08512 \\
\hline $\mathrm{C}$ & -5.50169 & -2.21016 & 0.33392 \\
\hline $\mathrm{C}$ & -4.46487 & -3.19010 & 0.45081 \\
\hline $\mathrm{C}$ & -3.15396 & -2.84482 & 0.32693 \\
\hline $\mathrm{C}$ & -6.85992 & -2.54893 & 0.45984 \\
\hline $\mathrm{C}$ & -7.84953 & -1.57994 & 0.34667 \\
\hline $\mathrm{C}$ & -7.50791 & -0.25136 & 0.10682 \\
\hline $\mathrm{C}$ & 2.28843 & -1.25341 & -0.23423 \\
\hline $\mathrm{C}$ & 3.15508 & -0.84532 & -1.26019 \\
\hline $\mathrm{C}$ & 4.48665 & -1.25318 & -1.26134 \\
\hline $\mathrm{C}$ & 4.97727 & -2.07503 & -0.24841 \\
\hline $\mathrm{C}$ & 4.12459 & -2.48812 & 0.77453 \\
\hline $\mathrm{C}$ & 2.79445 & -2.08078 & 0.78296 \\
\hline $\mathrm{C}$ & 2.21831 & 2.18282 & 0.52987 \\
\hline $\mathrm{C}$ & 3.51496 & 2.62105 & 0.24142 \\
\hline $\mathrm{C}$ & 4.39171 & 2.93053 & 1.27905 \\
\hline $\mathrm{C}$ & 3.97703 & 2.80604 & 2.60377 \\
\hline $\mathrm{C}$ & 2.68327 & 2.37208 & 2.89511 \\
\hline $\mathrm{C}$ & 1.80337 & 2.06258 & 1.86235 \\
\hline $\mathrm{H}$ & -2.33609 & 3.40989 & -0.60746 \\
\hline $\mathrm{H}$ & -0.03005 & -2.87038 & 0.17142 \\
\hline $\mathrm{H}$ & -4.24196 & 2.88730 & -0.58311 \\
\hline $\mathrm{H}$ & -6.55961 & 2.24112 & -0.35793 \\
\hline $\mathrm{H}$ & -4.74443 & -4.22075 & 0.64090 \\
\hline $\mathrm{H}$ & -2.38378 & -3.60172 & 0.41801 \\
\hline $\mathrm{H}$ & -7.12812 & -3.58283 & 0.64830 \\
\hline $\mathrm{H}$ & -8.89227 & -1.85896 & 0.44613 \\
\hline $\mathrm{H}$ & -8.28255 & 0.50294 & 0.02015 \\
\hline
\end{tabular}




\begin{tabular}{lrrr}
$\mathrm{H}$ & 2.78746 & -0.21055 & -2.05533 \\
$\mathrm{H}$ & 5.14078 & -0.93120 & -2.06379 \\
$\mathrm{H}$ & 4.49635 & -3.12198 & 1.57161 \\
$\mathrm{H}$ & 2.14044 & -2.39101 & 1.58924 \\
$\mathrm{H}$ & 3.83050 & 2.71005 & -0.79073 \\
$\mathrm{H}$ & 5.39711 & 3.26605 & 1.05277 \\
$\mathrm{H}$ & 4.66070 & 3.04621 & 3.41000 \\
$\mathrm{H}$ & 2.36130 & 2.27359 & 3.92521 \\
$\mathrm{H}$ & 0.79965 & 1.72601 & 2.09595 \\
$\mathrm{C}$ & 0.09133 & 4.46599 & -0.88476 \\
$\mathrm{H}$ & -0.78829 & 5.10750 & -0.80849 \\
$\mathrm{H}$ & 0.80702 & 4.77492 & -0.11639 \\
$\mathrm{H}$ & 0.56350 & 4.64550 & -1.85531 \\
$\mathrm{H}$ & 6.01453 & -2.38997 & -0.25484 \\
\hline
\end{tabular}

Table S7. Cartesian coordinates for compound 1b.

\begin{tabular}{lrrr}
\hline & $\mathrm{X}$ & $\mathrm{Y}$ & $\mathrm{Z}$ \\
\hline $\mathrm{P}$ & 1.13732 & 1.90003 & -0.45490 \\
$\mathrm{O}$ & 1.89705 & 2.13900 & -1.72543 \\
$\mathrm{~N}$ & 0.30622 & 0.38378 & -0.36152 \\
$\mathrm{C}$ & -0.21800 & 3.06439 & -0.19652 \\
$\mathrm{C}$ & -1.51655 & 2.69127 & -0.17785 \\
$\mathrm{C}$ & -2.00654 & 1.33108 & -0.24554 \\
$\mathrm{C}$ & -1.08499 & 0.27979 & -0.31698 \\
$\mathrm{C}$ & -1.43536 & -1.08146 & -0.29555 \\
$\mathrm{C}$ & -0.21287 & -1.82075 & -0.32063 \\
$\mathrm{C}$ & 0.83343 & -0.93595 & -0.36839 \\
$\mathrm{C}$ & -2.79834 & -1.44963 & -0.25198 \\
$\mathrm{C}$ & -3.77288 & -0.40715 & -0.21913 \\
$\mathrm{C}$ & -3.38376 & 0.97900 & -0.21055 \\
$\mathrm{C}$ & -4.42682 & 1.96566 & -0.17102 \\
$\mathrm{C}$ & -5.74261 & 1.62560 & -0.14355 \\
$\mathrm{C}$ & -6.16204 & 0.25578 & -0.14793 \\
$\mathrm{C}$ & -5.15937 & -0.75818 & -0.18388 \\
$\mathrm{C}$ & -5.55750 & -2.12994 & -0.18348 \\
$\mathrm{C}$ & -4.54513 & -3.14161 & -0.21250 \\
$\mathrm{C}$ & -3.22432 & -2.81367 & -0.24296 \\
$\mathrm{C}$ & -6.92559 & -2.45025 & -0.15239 \\
$\mathrm{C}$ & -7.89117 & -1.45124 & -0.12087 \\
$\mathrm{C}$ & -7.51534 & -0.11039 & -0.11787 \\
$\mathrm{C}$ & 2.26314 & -1.28399 & -0.40810 \\
$\mathrm{C}$ & 3.16234 & -0.74971 & -1.34454 \\
$\mathrm{C}$ & 4.48426 & -1.17155 & -1.38822 \\
$\mathrm{C}$ & 4.95819 & -2.15611 & -0.50786 \\
$\mathrm{C}$ & 4.06113 & -2.70122 & 0.42363 \\
& & & \\
& & $\mathrm{~S} 29$ & \\
\hline
\end{tabular}




\begin{tabular}{|c|c|c|c|}
\hline $\mathrm{C}$ & 2.74451 & -2.26731 & 0.47263 \\
\hline $\mathrm{C}$ & 2.21309 & 1.94081 & 1.00945 \\
\hline $\mathrm{C}$ & 3.51110 & 2.44692 & 0.88379 \\
\hline $\mathrm{C}$ & 4.33409 & 2.53723 & 2.00469 \\
\hline $\mathrm{C}$ & 3.86460 & 2.12392 & 3.25042 \\
\hline $\mathrm{C}$ & 2.57018 & 1.61867 & 3.37910 \\
\hline $\mathrm{C}$ & 1.74358 & 1.52913 & 2.26328 \\
\hline $\mathrm{H}$ & -2.24750 & 3.48669 & -0.08358 \\
\hline $\mathrm{H}$ & -0.09961 & -2.89312 & -0.33686 \\
\hline $\mathrm{H}$ & -4.16606 & 3.01543 & -0.17230 \\
\hline $\mathrm{H}$ & -6.50235 & 2.39939 & -0.11955 \\
\hline $\mathrm{H}$ & -4.85161 & -4.18212 & -0.21046 \\
\hline $\mathrm{H}$ & -2.47324 & -3.59458 & -0.26591 \\
\hline $\mathrm{H}$ & -7.22107 & -3.49388 & -0.15294 \\
\hline $\mathrm{H}$ & -8.94192 & -1.71675 & -0.09760 \\
\hline $\mathrm{H}$ & -8.27118 & 0.66714 & -0.09176 \\
\hline $\mathrm{H}$ & 2.83052 & 0.01205 & -2.03753 \\
\hline $\mathrm{H}$ & 5.15733 & -0.73612 & -2.11621 \\
\hline $\mathrm{H}$ & 4.40031 & -3.46336 & 1.11389 \\
\hline $\mathrm{H}$ & 2.07422 & -2.69703 & 1.20778 \\
\hline $\mathrm{H}$ & 3.87033 & 2.75750 & -0.08952 \\
\hline $\mathrm{H}$ & 5.34006 & 2.92785 & 1.90437 \\
\hline $\mathrm{H}$ & 4.50620 & 2.19436 & 4.12134 \\
\hline $\mathrm{H}$ & 2.20648 & 1.29379 & 4.34692 \\
\hline $\mathrm{H}$ & 0.73970 & 1.13375 & 2.36911 \\
\hline $\mathrm{C}$ & 0.20888 & 4.50942 & -0.10625 \\
\hline $\mathrm{H}$ & -0.65961 & 5.15288 & 0.04484 \\
\hline $\mathrm{H}$ & 0.90246 & 4.67091 & 0.72510 \\
\hline $\mathrm{H}$ & 0.72001 & 4.83162 & -1.01834 \\
\hline $\mathrm{N}$ & 6.30406 & -2.58818 & -0.55843 \\
\hline $\mathrm{C}$ & 6.96612 & -2.72347 & -1.81232 \\
\hline $\mathrm{C}$ & 6.32670 & -3.34993 & -2.89054 \\
\hline $\mathrm{C}$ & 8.26996 & -2.23897 & -1.98181 \\
\hline $\mathrm{C}$ & 6.97692 & -3.47747 & -4.11449 \\
\hline $\mathrm{H}$ & 5.32198 & -3.73502 & -2.76524 \\
\hline $\mathrm{C}$ & 8.91959 & -2.38576 & -3.20408 \\
\hline $\mathrm{H}$ & 8.76970 & -1.74986 & -1.15448 \\
\hline $\mathrm{C}$ & 8.27717 & -3.00058 & -4.27839 \\
\hline $\mathrm{H}$ & 6.46824 & -3.96448 & -4.93893 \\
\hline $\mathrm{H}$ & 9.92836 & -2.00530 & -3.31953 \\
\hline $\mathrm{H}$ & 8.78342 & -3.10711 & -5.23062 \\
\hline $\mathrm{C}$ & 7.00755 & -2.89381 & 0.64049 \\
\hline $\mathrm{C}$ & 6.90728 & -2.05549 & 1.75951 \\
\hline $\mathrm{C}$ & 7.81823 & -4.03475 & 0.71591 \\
\hline $\mathrm{C}$ & 7.59636 & -2.36115 & 2.92950 \\
\hline $\mathrm{H}$ & 6.28944 & -1.16733 & 1.70768 \\
\hline $\mathrm{C}$ & 8.51752 & -4.32352 & 1.88426 \\
\hline $\mathrm{H}$ & 7.89856 & -4.69062 & -0.14240 \\
\hline
\end{tabular}




$\begin{array}{llll}\mathrm{C} & 8.40831 & -3.49303 & 2.99913 \\ \mathrm{H} & 7.50812 & -1.70191 & 3.78586 \\ \mathrm{H} & 9.14046 & -5.21007 & 1.92569 \\ \mathrm{H} & 8.94903 & -3.72411 & 3.90941\end{array}$

Table S8. Cartesian coordinates for compound 2a.

\begin{tabular}{|c|c|c|c|}
\hline & $X$ & $\mathrm{Y}$ & $\mathrm{Z}$ \\
\hline $\mathrm{P}$ & 1.08073 & 1.82858 & -0.98826 \\
\hline $\mathrm{O}$ & 1.68776 & 1.79759 & -2.35873 \\
\hline $\mathrm{N}$ & 0.30246 & 0.36193 & -0.49900 \\
\hline $\mathrm{C}$ & -0.28109 & 3.01164 & -0.81857 \\
\hline $\mathrm{C}$ & -1.57110 & 2.62595 & -0.63430 \\
\hline $\mathrm{C}$ & -2.02378 & 1.27660 & -0.42288 \\
\hline $\mathrm{C}$ & -1.07851 & 0.24491 & -0.34939 \\
\hline $\mathrm{C}$ & -1.38981 & -1.08915 & -0.03903 \\
\hline $\mathrm{C}$ & -0.15048 & -1.79966 & 0.00598 \\
\hline $\mathrm{C}$ & 0.86569 & -0.92612 & -0.27880 \\
\hline $\mathrm{C}$ & -2.73656 & -1.46022 & 0.17098 \\
\hline $\mathrm{C}$ & -3.73725 & -0.44657 & 0.06143 \\
\hline $\mathrm{C}$ & -3.38936 & 0.91726 & -0.23495 \\
\hline $\mathrm{C}$ & -4.45388 & 1.87479 & -0.32930 \\
\hline $\mathrm{C}$ & -5.75510 & 1.52755 & -0.14142 \\
\hline $\mathrm{C}$ & -6.13340 & 0.18152 & 0.16657 \\
\hline $\mathrm{C}$ & -5.10714 & -0.80321 & 0.26621 \\
\hline $\mathrm{C}$ & -5.46431 & -2.15029 & 0.57664 \\
\hline $\mathrm{C}$ & -4.42771 & -3.13180 & 0.67944 \\
\hline $\mathrm{C}$ & -3.12176 & -2.79941 & 0.48619 \\
\hline $\mathrm{C}$ & -6.81641 & -2.47670 & 0.77529 \\
\hline $\mathrm{C}$ & -7.80657 & -1.50646 & 0.67312 \\
\hline $\mathrm{C}$ & -7.47054 & -0.18966 & 0.37157 \\
\hline $\mathrm{C}$ & 2.29725 & 2.18799 & 0.30888 \\
\hline $\mathrm{C}$ & 3.57367 & 2.62497 & -0.06057 \\
\hline $\mathrm{C}$ & 4.50309 & 2.96126 & 0.92118 \\
\hline $\mathrm{C}$ & 4.16142 & 2.86386 & 2.26871 \\
\hline $\mathrm{C}$ & 2.88779 & 2.43116 & 2.64000 \\
\hline $\mathrm{C}$ & 1.95459 & 2.09608 & 1.66397 \\
\hline $\mathrm{H}$ & -2.31777 & 3.41114 & -0.63516 \\
\hline $\mathrm{H}$ & -0.00800 & -2.85138 & 0.19693 \\
\hline $\mathrm{H}$ & -4.22528 & 2.90496 & -0.56681 \\
\hline $\mathrm{H}$ & -6.53345 & 2.27814 & -0.22586 \\
\hline $\mathrm{H}$ & -4.70316 & -4.15404 & 0.91518 \\
\hline $\mathrm{H}$ & -2.35233 & -3.55790 & 0.56747 \\
\hline $\mathrm{H}$ & -7.08028 & -3.50184 & 1.01131 \\
\hline $\mathrm{H}$ & -8.84470 & -1.77605 & 0.82922 \\
\hline $\mathrm{H}$ & -8.24484 & 0.56575 & 0.29310 \\
\hline
\end{tabular}




\begin{tabular}{|c|c|c|c|}
\hline $\mathrm{H}$ & 3.83279 & 2.69407 & -1.10968 \\
\hline $\mathrm{H}$ & 5.49231 & 3.29734 & 0.63334 \\
\hline $\mathrm{H}$ & 4.88645 & 3.12503 & 3.03099 \\
\hline $\mathrm{H}$ & 2.62290 & 2.35440 & 3.68796 \\
\hline $\mathrm{H}$ & 0.96649 & 1.76119 & 1.95840 \\
\hline $\mathrm{C}$ & 0.07467 & 4.44768 & -0.94347 \\
\hline $\mathrm{C}$ & 0.98778 & 4.90097 & -1.90458 \\
\hline $\mathrm{C}$ & -0.51184 & 5.39249 & -0.08604 \\
\hline $\mathrm{C}$ & 1.28695 & 6.25825 & -2.01146 \\
\hline $\mathrm{H}$ & 1.44201 & 4.19282 & -2.58554 \\
\hline $\mathrm{C}$ & -0.21108 & 6.74397 & -0.20699 \\
\hline $\mathrm{H}$ & -1.19675 & 5.06544 & 0.68492 \\
\hline $\mathrm{C}$ & 0.69266 & 7.19117 & -1.17019 \\
\hline $\mathrm{H}$ & 0.92173 & 8.24347 & -1.26544 \\
\hline $\mathrm{C}$ & -0.81128 & 7.73880 & 0.74931 \\
\hline $\mathrm{C}$ & 2.29295 & 6.69709 & -3.04126 \\
\hline $\mathrm{F}$ & 0.04039 & 8.03808 & 1.75994 \\
\hline $\mathrm{F}$ & -1.10964 & 8.90766 & 0.14022 \\
\hline $\mathrm{F}$ & -1.94650 & 7.28430 & 1.32025 \\
\hline $\mathrm{F}$ & 2.24625 & 8.02509 & -3.27401 \\
\hline $\mathrm{F}$ & 3.55988 & 6.41110 & -2.65453 \\
\hline $\mathrm{F}$ & 2.10529 & 6.07640 & -4.22701 \\
\hline $\mathrm{C}$ & 2.30119 & -1.25744 & -0.33772 \\
\hline $\mathrm{C}$ & 3.12835 & -0.88549 & -1.40889 \\
\hline $\mathrm{C}$ & 2.84324 & -2.05382 & 0.68548 \\
\hline $\mathrm{C}$ & 4.45801 & -1.29749 & -1.44757 \\
\hline $\mathrm{H}$ & 2.73175 & -0.27804 & -2.21143 \\
\hline $\mathrm{C}$ & 4.17118 & -2.46565 & 0.63933 \\
\hline $\mathrm{H}$ & 2.21973 & -2.33596 & 1.52555 \\
\hline $\mathrm{C}$ & 4.98498 & -2.08795 & -0.42794 \\
\hline $\mathrm{H}$ & 5.08167 & -1.00372 & -2.28428 \\
\hline $\mathrm{H}$ & 4.57180 & -3.07501 & 1.44146 \\
\hline $\mathrm{H}$ & 6.02064 & -2.40604 & -0.46354 \\
\hline
\end{tabular}

Table S9. Cartesian coordinates for compound $\mathbf{2 b .}$

\begin{tabular}{cccc}
\hline & $\mathrm{X}$ & $\mathrm{Y}$ & $\mathrm{Z}$ \\
\hline $\mathrm{P}$ & 1.09355 & 1.82685 & -0.83772 \\
$\mathrm{O}$ & 1.72796 & 1.90910 & -2.19387 \\
$\mathrm{~N}$ & 0.27307 & 0.34193 & -0.50352 \\
$\mathrm{C}$ & -0.24458 & 3.02140 & -0.58302 \\
$\mathrm{C}$ & -1.54667 & 2.65179 & -0.46081 \\
$\mathrm{C}$ & -2.03421 & 1.29919 & -0.39657 \\
& &
\end{tabular}




\begin{tabular}{|c|c|c|c|}
\hline $\mathrm{C}$ & -1.11392 & 0.24326 & -0.40611 \\
\hline $\mathrm{C}$ & -1.46244 & -1.10945 & -0.25623 \\
\hline $\mathrm{C}$ & -0.24038 & -1.85054 & -0.25543 \\
\hline $\mathrm{C}$ & 0.80335 & -0.97646 & -0.41360 \\
\hline $\mathrm{C}$ & -2.82381 & -1.46874 & -0.14452 \\
\hline $\mathrm{C}$ & -3.79936 & -0.42523 & -0.17553 \\
\hline $\mathrm{C}$ & -3.41306 & 0.95516 & -0.29390 \\
\hline $\mathrm{C}$ & -4.45341 & 1.94310 & -0.30900 \\
\hline $\mathrm{C}$ & -5.76830 & 1.60745 & -0.22054 \\
\hline $\mathrm{C}$ & -6.18591 & 0.24309 & -0.10381 \\
\hline $\mathrm{C}$ & -5.18389 & -0.77100 & -0.07914 \\
\hline $\mathrm{C}$ & -5.58067 & -2.13731 & 0.04238 \\
\hline $\mathrm{C}$ & -4.56824 & -3.14865 & 0.07555 \\
\hline $\mathrm{C}$ & -3.24845 & -2.82640 & -0.01076 \\
\hline $\mathrm{C}$ & -6.94696 & -2.45324 & 0.12822 \\
\hline $\mathrm{C}$ & -7.91316 & -1.45417 & 0.09859 \\
\hline $\mathrm{C}$ & -7.53845 & -0.11839 & -0.01483 \\
\hline $\mathrm{C}$ & 2.23175 & -1.32739 & -0.46238 \\
\hline $\mathrm{C}$ & 3.10572 & -0.87953 & -1.46576 \\
\hline $\mathrm{C}$ & 4.42728 & -1.30210 & -1.50523 \\
\hline $\mathrm{C}$ & 4.92723 & -2.20364 & -0.55258 \\
\hline $\mathrm{C}$ & 4.05407 & -2.66411 & 0.44585 \\
\hline $\mathrm{C}$ & 2.73831 & -2.22805 & 0.48964 \\
\hline $\mathrm{C}$ & 2.29439 & 2.03600 & 0.50637 \\
\hline $\mathrm{C}$ & 3.58898 & 2.46598 & 0.19670 \\
\hline $\mathrm{C}$ & 4.51073 & 2.68574 & 1.21805 \\
\hline $\mathrm{C}$ & 4.14343 & 2.47824 & 2.54651 \\
\hline $\mathrm{C}$ & 2.85202 & 2.05091 & 2.85833 \\
\hline $\mathrm{C}$ & 1.92672 & 1.83218 & 1.84259 \\
\hline $\mathrm{H}$ & -2.27562 & 3.45153 & -0.40260 \\
\hline $\mathrm{H}$ & -0.12652 & -2.92028 & -0.18005 \\
\hline $\mathrm{H}$ & -4.19506 & 2.98917 & -0.40388 \\
\hline $\mathrm{H}$ & -6.52757 & 2.38168 & -0.24093 \\
\hline $\mathrm{H}$ & -4.87361 & -4.18505 & 0.17076 \\
\hline $\mathrm{H}$ & -2.49759 & -3.60716 & 0.01508 \\
\hline $\mathrm{H}$ & -7.24109 & -3.49316 & 0.21909 \\
\hline $\mathrm{H}$ & -8.96278 & -1.71614 & 0.16543 \\
\hline $\mathrm{H}$ & -8.29391 & 0.65954 & -0.03556 \\
\hline $\mathrm{H}$ & 2.75455 & -0.18523 & -2.21784 \\
\hline $\mathrm{H}$ & 5.07942 & -0.93272 & -2.28657 \\
\hline $\mathrm{H}$ & 4.41130 & -3.36225 & 1.19214 \\
\hline $\mathrm{H}$ & 2.08849 & -2.59093 & 1.27732 \\
\hline $\mathrm{H}$ & 3.86810 & 2.62073 & -0.83808 \\
\hline $\mathrm{H}$ & 5.51339 & 3.01792 & 0.97572 \\
\hline $\mathrm{H}$ & 4.86173 & 2.65032 & 3.33988 \\
\hline $\mathrm{H}$ & 2.56703 & 1.88844 & 3.89114 \\
\hline $\mathrm{H}$ & 0.92523 & 1.50021 & 2.09145 \\
\hline $\mathrm{N}$ & 6.27132 & -2.63668 & -0.59510 \\
\hline
\end{tabular}




$\begin{array}{lrrr}\text { C } & 6.92331 & -2.84707 & -1.84406 \\ \mathrm{C} & 6.27697 & -3.53598 & -2.87924 \\ \mathrm{C} & 8.22641 & -2.37511 & -2.04978 \\ \mathrm{C} & 6.91984 & -3.73623 & -4.09735 \\ \mathrm{H} & 5.27273 & -3.91204 & -2.72572 \\ \mathrm{C} & 8.86863 & -2.59446 & -3.26514 \\ \mathrm{H} & 8.73150 & -1.83794 & -1.25621 \\ \mathrm{C} & 8.21927 & -3.27092 & -4.29726 \\ \mathrm{H} & 6.40594 & -4.27092 & -4.88832 \\ \mathrm{H} & 9.87696 & -2.22259 & -3.40881 \\ \mathrm{H} & 8.71945 & -3.43418 & -5.24464 \\ \mathrm{C} & 6.99079 & -2.87012 & 0.61253 \\ \mathrm{C} & 6.93911 & -1.94419 & 1.66312 \\ \mathrm{C} & 7.76775 & -4.02660 & 0.76044 \\ \mathrm{C} & 7.64266 & -2.18007 & 2.84073 \\ \mathrm{H} & 6.34750 & -1.04356 & 1.55264 \\ \mathrm{C} & 8.48149 & -4.24696 & 1.93508 \\ \mathrm{H} & 7.80972 & -4.74799 & -0.04655 \\ \mathrm{C} & 8.42018 & -3.32920 & 2.98321 \\ \mathrm{H} & 7.59323 & -1.45410 & 3.64458 \\ \mathrm{H} & 9.07817 & -5.14679 & 2.03457 \\ \mathrm{H} & 8.97235 & -3.50627 & 3.89872 \\ \mathrm{C} & 0.14546 & 4.45432 & -0.57429 \\ \mathrm{C} & 1.07345 & 4.97068 & -1.49169 \\ \mathrm{C} & -0.41659 & 5.32979 & 0.36499 \\ \mathrm{C} & 1.40963 & 6.32107 & -1.47147 \\ \mathrm{H} & 1.52084 & 4.31364 & -2.22608 \\ \mathrm{C} & -0.07750 & 6.68050 & 0.37054 \\ \mathrm{H} & -1.11049 & 4.94963 & 1.10392 \\ \mathrm{C} & 0.83808 & 7.18944 & -0.54544 \\ \mathrm{H} & 1.10515 & 8.23658 & -0.53350 \\ \mathrm{C} & -0.66551 & 7.57543 & 1.42762 \\ \mathrm{C} & 2.36117 & 6.85438 & -2.50832 \\ \mathrm{~F} & -0.05528 & 7.40395 & 2.62525 \\ \mathrm{~F} & -0.55217 & 8.88285 & 1.11623 \\ \mathrm{~F} & -1.97891 & 7.32389 & 1.62840 \\ \mathrm{~F} & 2.97611 & 7.98634 & -2.10358 \\ \mathrm{~F} & 3.32734 & 5.96264 & -2.81731 \\ \mathrm{~F} & 1.72442 & 7.15128 & -3.66702\end{array}$

Table S10. Cartesian coordinates for the first excited state $\left(S_{1}\right)$ of compound $\mathbf{2 b}$.

\begin{tabular}{crrr}
\hline & $\mathrm{X}$ & $\mathrm{Y}$ & $\mathrm{Z}$ \\
\hline $\mathrm{P}$ & 0.60093 & -0.68070 & -0.52163 \\
$\mathrm{O}$ & -0.08151 & -1.21096 & -1.75320 \\
$\mathrm{~N}$ & 0.48327 & 1.05772 & -0.36509 \\
\multicolumn{2}{c}{$\mathrm{S} 34$}
\end{tabular}




\begin{tabular}{|c|c|c|c|}
\hline $\mathrm{C}$ & 2.36036 & -0.94440 & -0.40561 \\
\hline $\mathrm{C}$ & 3.26878 & 0.11631 & -0.42278 \\
\hline $\mathrm{C}$ & 2.95183 & 1.48994 & -0.41723 \\
\hline $\mathrm{C}$ & 1.60297 & 1.89665 & -0.36922 \\
\hline $\mathrm{C}$ & 1.18059 & 3.22863 & -0.24093 \\
\hline $\mathrm{C}$ & -0.22076 & 3.19908 & -0.11604 \\
\hline $\mathrm{C}$ & -0.65760 & 1.87444 & -0.20648 \\
\hline $\mathrm{C}$ & 2.13341 & 4.30038 & -0.24171 \\
\hline $\mathrm{C}$ & 3.51152 & 3.94039 & -0.34280 \\
\hline $\mathrm{C}$ & 3.92607 & 2.56483 & -0.43026 \\
\hline $\mathrm{C}$ & 5.31915 & 2.30143 & -0.52586 \\
\hline $\mathrm{C}$ & 6.25755 & 3.29952 & -0.53038 \\
\hline $\mathrm{C}$ & 5.88237 & 4.67105 & -0.44067 \\
\hline $\mathrm{C}$ & 4.49174 & 4.98402 & -0.34823 \\
\hline $\mathrm{C}$ & 4.08964 & 6.35557 & -0.25899 \\
\hline $\mathrm{C}$ & 2.70381 & 6.66046 & -0.16245 \\
\hline $\mathrm{C}$ & 1.76213 & 5.65836 & -0.15339 \\
\hline $\mathrm{C}$ & 5.07997 & 7.36428 & -0.26739 \\
\hline $\mathrm{C}$ & 6.42728 & 7.04141 & -0.35850 \\
\hline $\mathrm{C}$ & 6.83159 & 5.71168 & -0.44397 \\
\hline $\mathrm{C}$ & -2.05189 & 1.48155 & -0.18896 \\
\hline $\mathrm{C}$ & -2.59029 & 0.38116 & -0.89789 \\
\hline $\mathrm{C}$ & -3.94220 & 0.11377 & -0.88551 \\
\hline $\mathrm{C}$ & -4.83806 & 0.91862 & -0.14589 \\
\hline $\mathrm{C}$ & -4.31099 & 2.01854 & 0.57233 \\
\hline $\mathrm{C}$ & -2.96430 & 2.29137 & 0.53837 \\
\hline $\mathrm{C}$ & -0.19792 & -1.31093 & 0.99152 \\
\hline $\mathrm{C}$ & -1.12138 & -2.35756 & 0.89831 \\
\hline $\mathrm{C}$ & -1.69584 & -2.88772 & 2.05286 \\
\hline $\mathrm{C}$ & -1.35418 & -2.37409 & 3.30180 \\
\hline $\mathrm{C}$ & -0.43304 & -1.32915 & 3.39992 \\
\hline $\mathrm{C}$ & 0.14767 & -0.80260 & 2.25087 \\
\hline $\mathrm{H}$ & 4.31616 & -0.15511 & -0.44323 \\
\hline $\mathrm{H}$ & -0.87850 & 4.04823 & -0.02250 \\
\hline $\mathrm{H}$ & 5.66269 & 1.27821 & -0.60443 \\
\hline $\mathrm{H}$ & 7.31065 & 3.05066 & -0.60687 \\
\hline $\mathrm{H}$ & 2.39865 & 7.69896 & -0.09653 \\
\hline $\mathrm{H}$ & 0.71076 & 5.91352 & -0.08068 \\
\hline $\mathrm{H}$ & 4.77033 & 8.40169 & -0.19984 \\
\hline $\mathrm{H}$ & 7.17080 & 7.83089 & -0.36287 \\
\hline $\mathrm{H}$ & 7.88497 & 5.46347 & -0.51558 \\
\hline $\mathrm{H}$ & -1.93673 & -0.25911 & -1.47511 \\
\hline $\mathrm{H}$ & -4.31912 & -0.73725 & -1.43648 \\
\hline $\mathrm{H}$ & -4.97412 & 2.66015 & 1.13632 \\
\hline $\mathrm{H}$ & -2.59356 & 3.13876 & 1.09993 \\
\hline $\mathrm{H}$ & -1.38676 & -2.75049 & -0.07519 \\
\hline $\mathrm{H}$ & -2.40710 & -3.70191 & 1.97485 \\
\hline $\mathrm{H}$ & -1.80102 & -2.78726 & 4.19894 \\
\hline
\end{tabular}




\begin{tabular}{|c|c|c|c|}
\hline $\mathrm{H}$ & -0.16564 & -0.92888 & 4.37100 \\
\hline $\mathrm{H}$ & 0.86896 & 0.00241 & 2.33575 \\
\hline $\mathrm{N}$ & -6.19985 & 0.64166 & -0.12473 \\
\hline $\mathrm{C}$ & -6.83732 & 0.00557 & -1.23232 \\
\hline $\mathrm{C}$ & -6.59466 & 0.45446 & -2.53696 \\
\hline $\mathrm{C}$ & -7.72232 & -1.05694 & -1.01012 \\
\hline $\mathrm{C}$ & -7.22562 & -0.16706 & -3.60873 \\
\hline $\mathrm{H}$ & -5.92804 & 1.29142 & -2.70316 \\
\hline $\mathrm{C}$ & -8.35059 & -1.66783 & -2.08917 \\
\hline $\mathrm{H}$ & -7.90303 & -1.40409 & -0.00057 \\
\hline $\mathrm{C}$ & -8.10382 & -1.22855 & -3.39035 \\
\hline $\mathrm{H}$ & -7.03959 & 0.18766 & -4.61540 \\
\hline $\mathrm{H}$ & -9.02727 & -2.49557 & -1.91352 \\
\hline $\mathrm{H}$ & -8.59497 & -1.70853 & -4.22823 \\
\hline $\mathrm{C}$ & -6.99765 & 0.98737 & 1.00813 \\
\hline $\mathrm{C}$ & -6.56688 & 0.65221 & 2.29808 \\
\hline $\mathrm{C}$ & -8.21984 & 1.64564 & 0.82554 \\
\hline $\mathrm{C}$ & -7.35308 & 0.98534 & 3.39557 \\
\hline $\mathrm{H}$ & -5.63189 & 0.12246 & 2.43186 \\
\hline $\mathrm{C}$ & -8.99894 & 1.97107 & 1.93001 \\
\hline $\mathrm{H}$ & -8.54531 & 1.90711 & -0.17355 \\
\hline $\mathrm{C}$ & -8.56926 & 1.64471 & 3.21685 \\
\hline $\mathrm{H}$ & -7.01998 & 0.71733 & 4.39114 \\
\hline $\mathrm{H}$ & -9.93991 & 2.48833 & 1.78537 \\
\hline $\mathrm{H}$ & -9.18003 & 1.89977 & 4.07454 \\
\hline $\mathrm{C}$ & 2.81072 & -2.33314 & -0.28620 \\
\hline $\mathrm{C}$ & 2.05492 & -3.42262 & -0.77400 \\
\hline $\mathrm{C}$ & 4.04310 & -2.64576 & 0.33452 \\
\hline $\mathrm{C}$ & 2.50277 & -4.73114 & -0.63941 \\
\hline $\mathrm{H}$ & 1.12206 & -3.23832 & -1.28940 \\
\hline $\mathrm{C}$ & 4.48640 & -3.95643 & 0.44277 \\
\hline $\mathrm{H}$ & 4.64766 & -1.85483 & 0.75659 \\
\hline $\mathrm{C}$ & 3.72532 & -5.02371 & -0.03706 \\
\hline $\mathrm{H}$ & 4.07225 & -6.04264 & 0.05629 \\
\hline $\mathrm{C}$ & 5.77067 & -4.24467 & 1.16847 \\
\hline $\mathrm{C}$ & 1.68307 & -5.84319 & -1.23047 \\
\hline $\mathrm{F}$ & 5.56351 & -4.48383 & 2.48883 \\
\hline $\mathrm{F}$ & 6.40105 & -5.33684 & 0.67935 \\
\hline $\mathrm{F}$ & 6.64776 & -3.21827 & 1.10039 \\
\hline $\mathrm{F}$ & 1.90363 & -7.02795 & -0.61707 \\
\hline $\mathrm{F}$ & 0.35423 & -5.60034 & -1.15401 \\
\hline $\mathrm{F}$ & 1.95969 & -6.03592 & -2.54533 \\
\hline
\end{tabular}




\section{References}

1. Chen, L.; Peng, S.; Chen, Y. ACS Appl. Mater. Interfaces 2014, 6, 8115-8123.

2. Lemaire, M.; Guy, A.; Roussel, J.; Guette, N. Tetrahedron 1987, 43, 835-844.

3. Mujkic, M.; Lentz, D. Dalton Trans. 2012, 41, 839-849.

4. Lin, C.-H.; Chang, Y.-Y.; Hung, J.-Y.; Lin, C.-Y.; Chi, Y.; Chung, M.-W.; Lin, C.-L.; Chou, P.T.; Lee, G.-H.; Chang, C.-H.; Lin, W. C. Angew. Chem., Int. Ed. 2011, 50, 3182-3186.

5. Zielinska, B. Polycyclic Aromat. Compd. 1990, 1, 207-211.

6. Sheldrick, G. M.; Bruker/Siemens Area Detector Absorption Correction Program, Bruker AXS, Madison, WI, 1998.

7. Sheldrick, G. M. Acta Cryst. C 2015, 71, 3-8.

8. Lakowicz, J. R. Principles of Fluorescence Spectroscopy, 3rd ed.; Springer: New York, 1999.

9. (a) Lippert, V. E. Z. Naturforsch., A: Phys. Sci. 1955, 10, 541-545. (b) Mataga, N.; Kaifu, Y.; Koizumi, M. Bull. Chem. Soc. Jpn. 1956, 29, 465-470.

10. Pommerehne, J.; Vestweber, H.; Guss, W.; Mahrt, R. F.; Bassler, H.; Porsch, M.; Daub, J. Adv. Mater. 1995, 7, 551-554.

11. Gaussian 09, Revision E.01, Frisch, M. J.; Trucks, G. W.; Schlegel, H. B.; Scuseria, G. E.; Robb, M. A.; Cheeseman, J. R.; Scalmani, G.; Barone, V.; Mennucci, B.; Petersson, G. A.; Nakatsuji, H.; Caricato, M.; Li, X.; Hratchian, H. P.; Izmaylov, A. F.; Bloino, J.; Zheng, G.; Sonnenberg, J. L.; Hada, M.; Ehara, M.; Toyota, K.; Fukuda, R.; Hasegawa, J.; Ishida, M.; Nakajima, T.; Honda, Y.; Kitao, O.; Nakai, H.; Vreven, T.; Montgomery, J. A., Jr.; Peralta, J. E.; Ogliaro, F.; Bearpark, M.; Heyd, J. J.; Brothers, E.; Kudin, K. N.; Staroverov, V. N.; Kobayashi, R.; Normand, J.; Raghavachari, K.; Rendell, A.; Burant, J. C.; Iyengar, S. S.; Tomasi, J.; Cossi, M.; Rega, N.; Millam, J. M.; Klene, M.; Knox, J. E.; Cross, J. B.; Bakken, V.; Adamo, C.; Jaramillo, J.; Gomperts, R.; Stratmann, R. E.; Yazyev, O.; Austin, A. J.; Cammi, R.; Pomelli, C.; Ochterski, J. W.; Martin, R. L.; Morokuma, K.; Zakrzewski, V. G.; Voth, G. A.; Salvador, P.; Dannenberg, J. J.; Dapprich, S.; Daniels, A. D.; Farkas, Ö.; Foresman, J. B.; Ortiz, J. V.; Cioslowski, J.; Fox, D. J. Gaussian, Inc., Wallingford CT, 2013.

12. Yanai, T.; Tew, D. P.; Handy, N. C. Chem. Phys. Lett. 2004, 393, 51-57.

13. Scalmani, G.; Frisch, M. J. J. Chem. Phys. 2010, 132, 114110.

14. Lu, T.; Chen, F. J. Comput. Chem. 2012, 33, 580-592. 


\section{Copies of NMR Spectra for New Compounds}
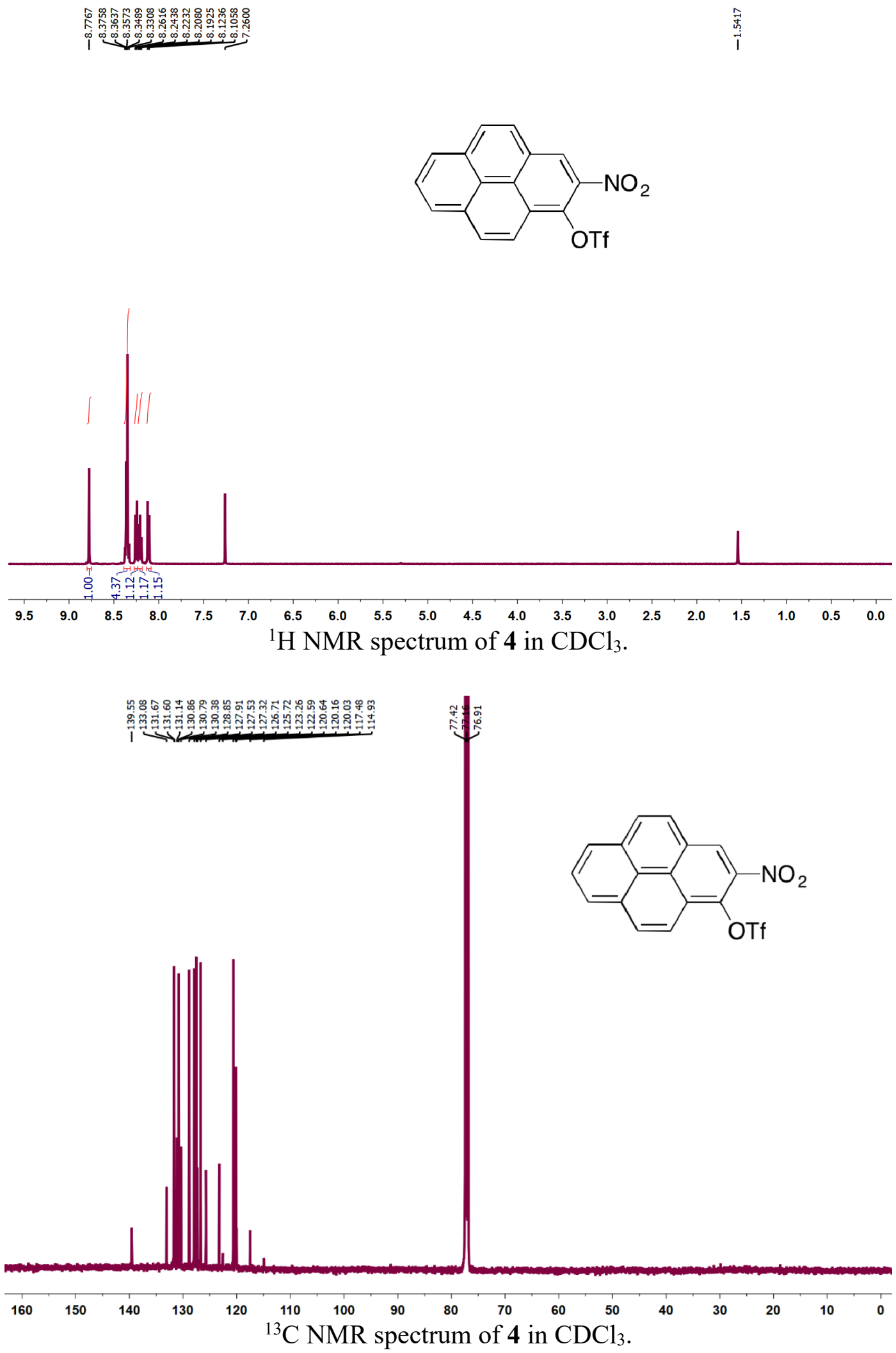

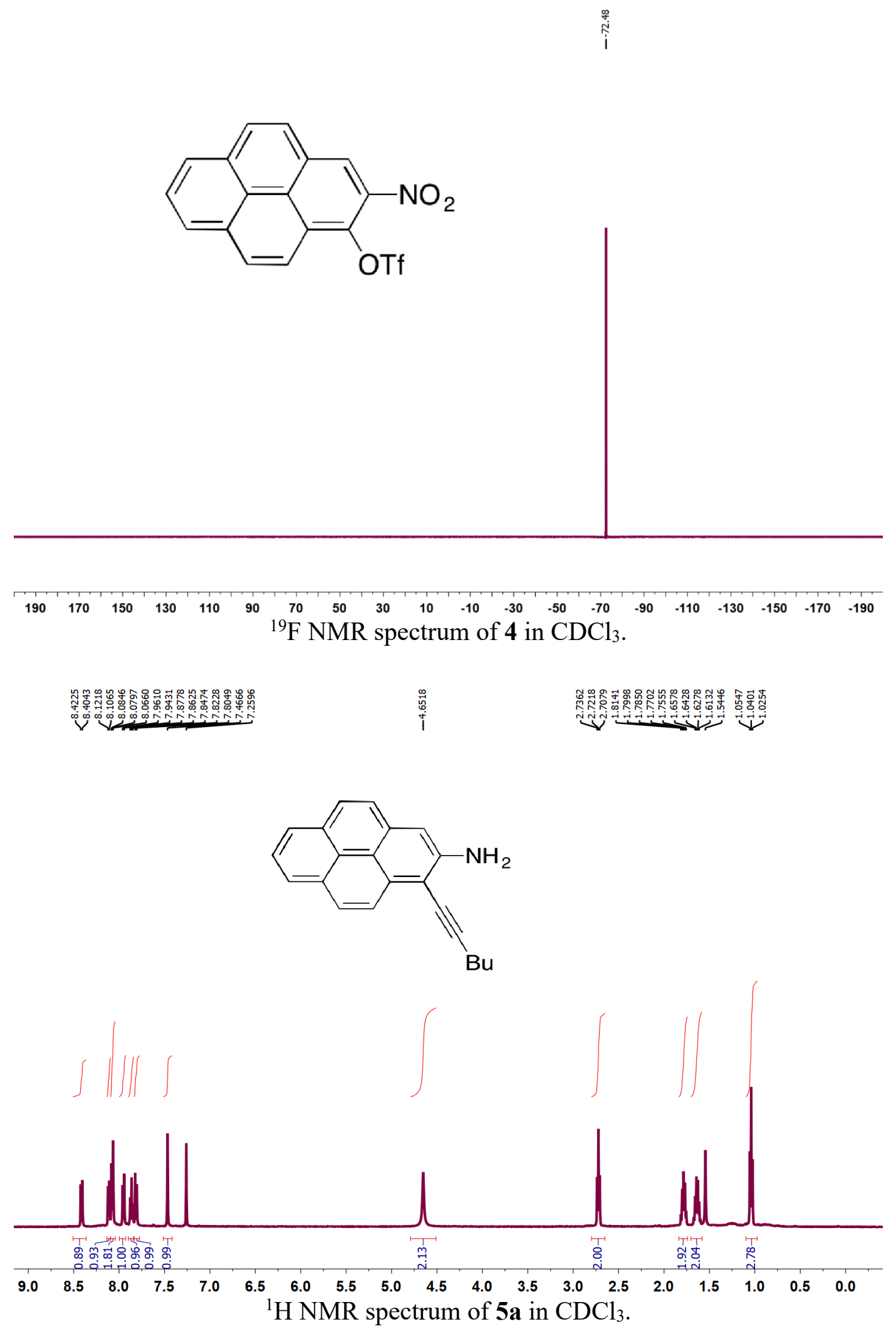

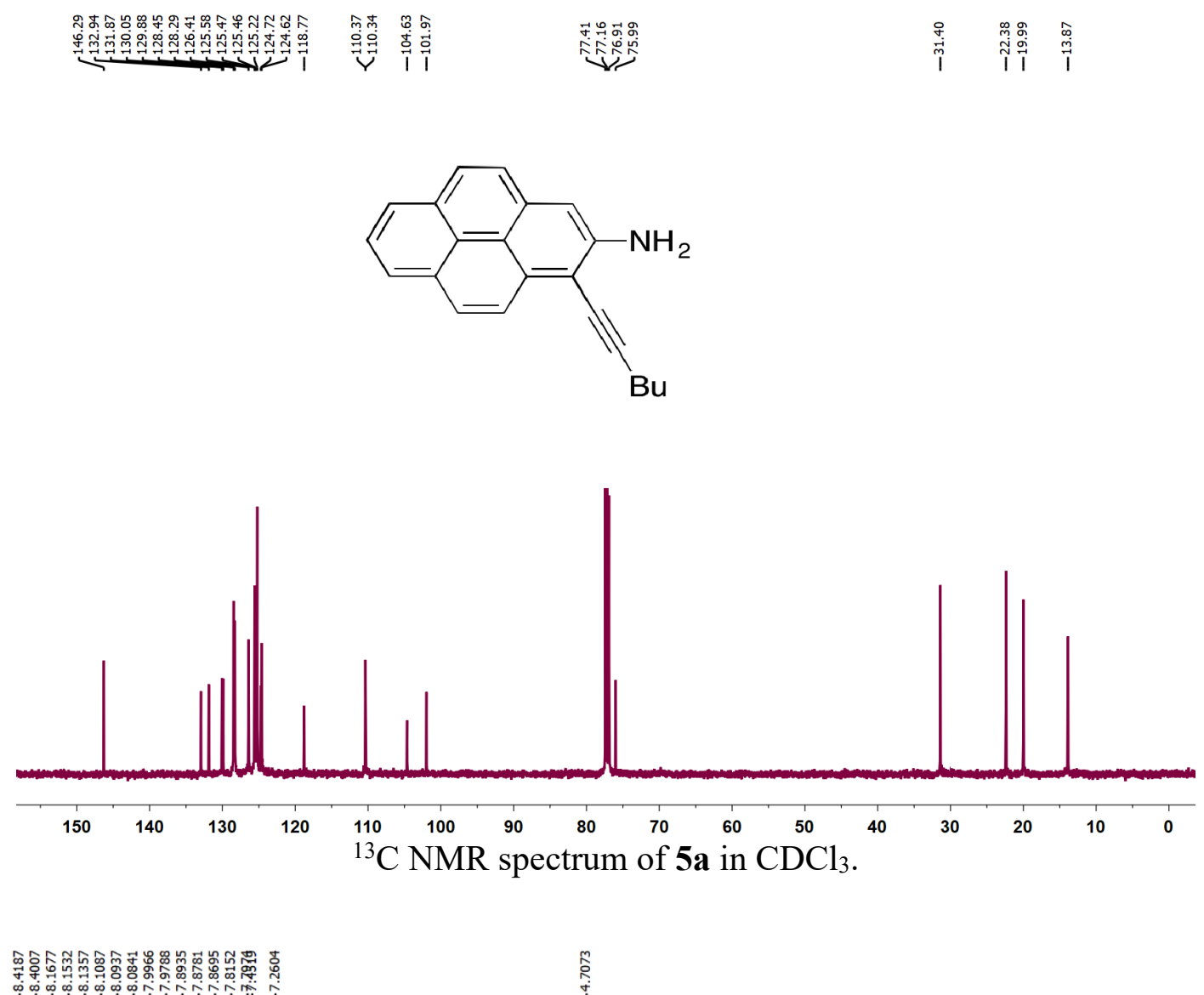



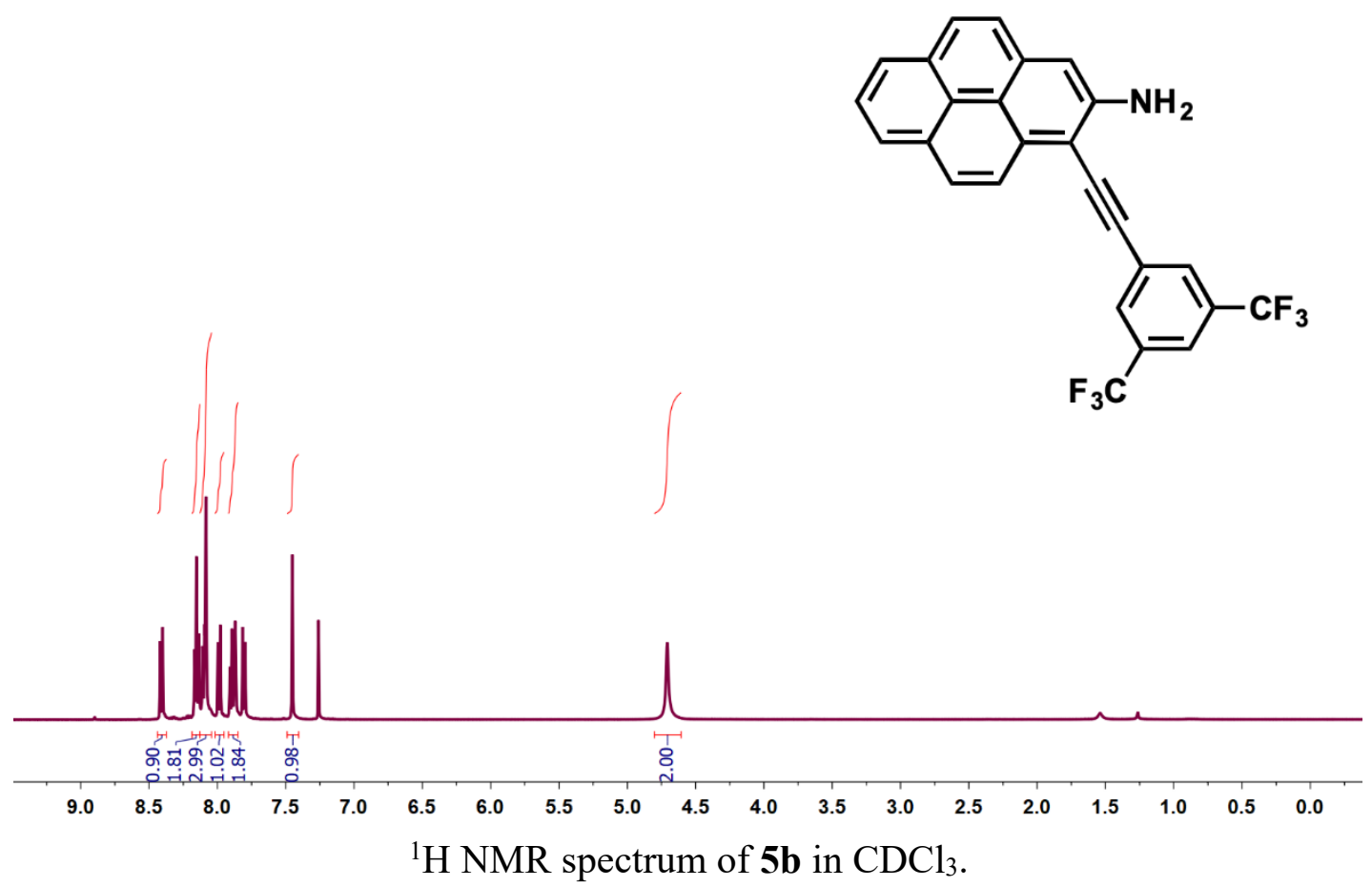



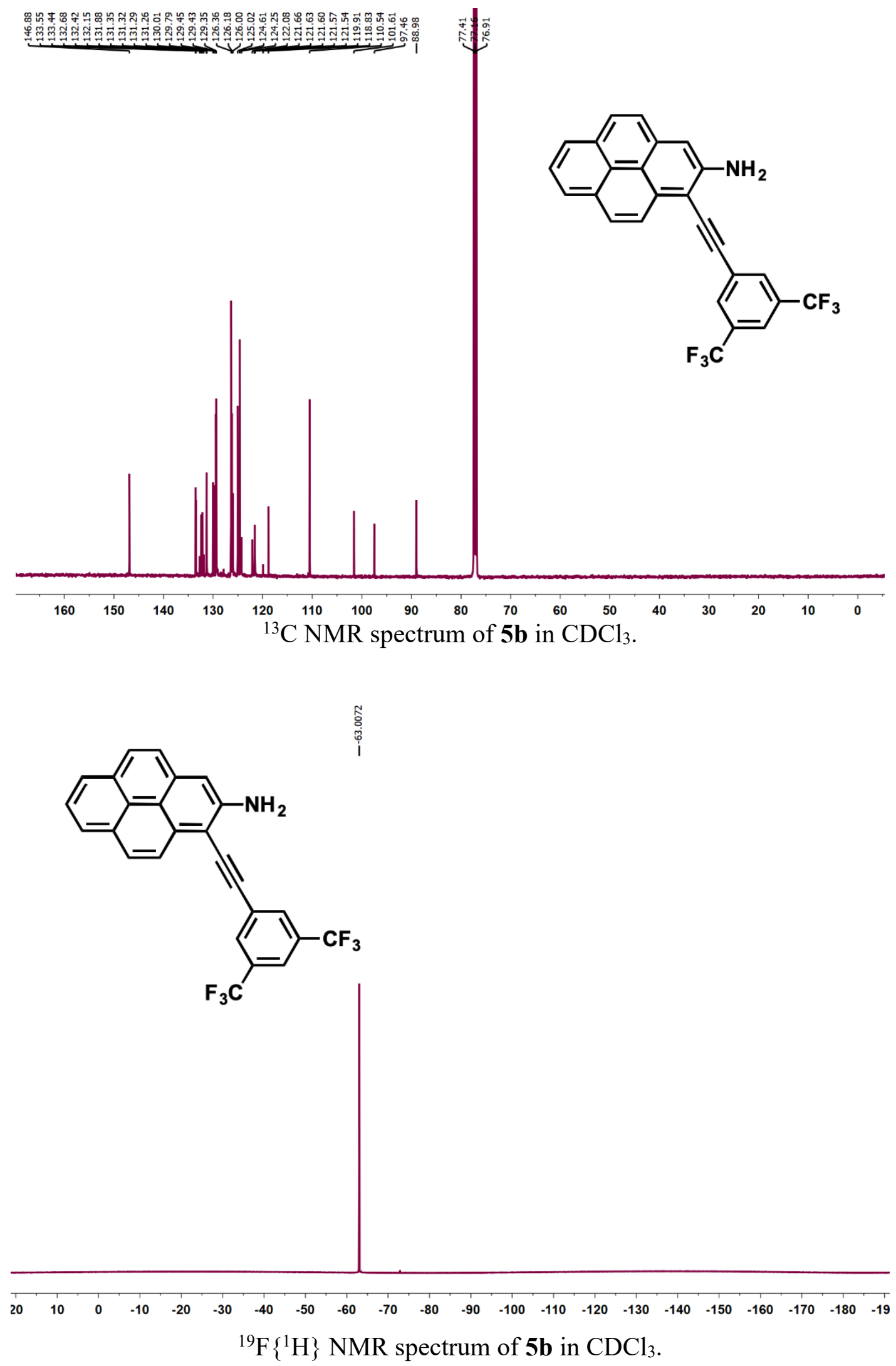
<smiles>CC(C)CC1=Cc2c(c(I)c3ccc4cccc5ccc2c3c45)NP1(=O)c1ccccc1</smiles>

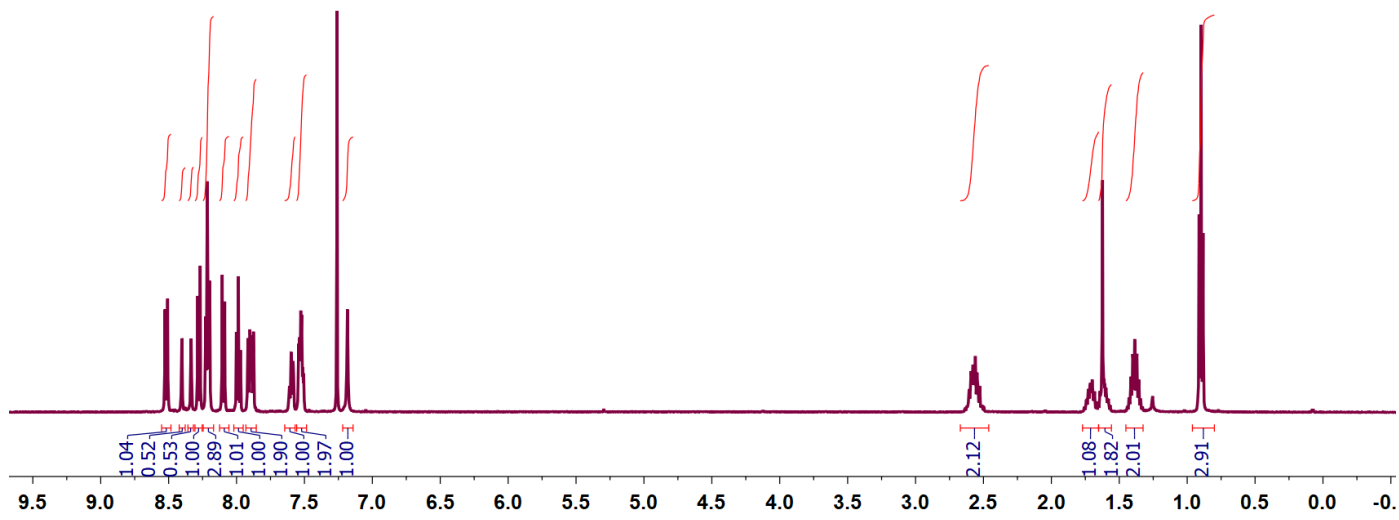

${ }^{1} \mathrm{H}$ NMR spectrum of $\mathbf{6 a}$ in $\mathrm{CDCl}_{3}$.

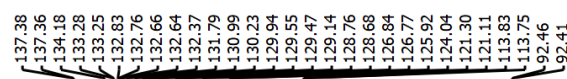

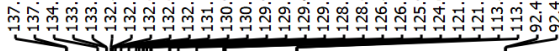<smiles>CC(C)C1=Cc2c(c(I)c3ccc4cccc5ccc2c3c45)NP1(=O)c1ccccc1</smiles>

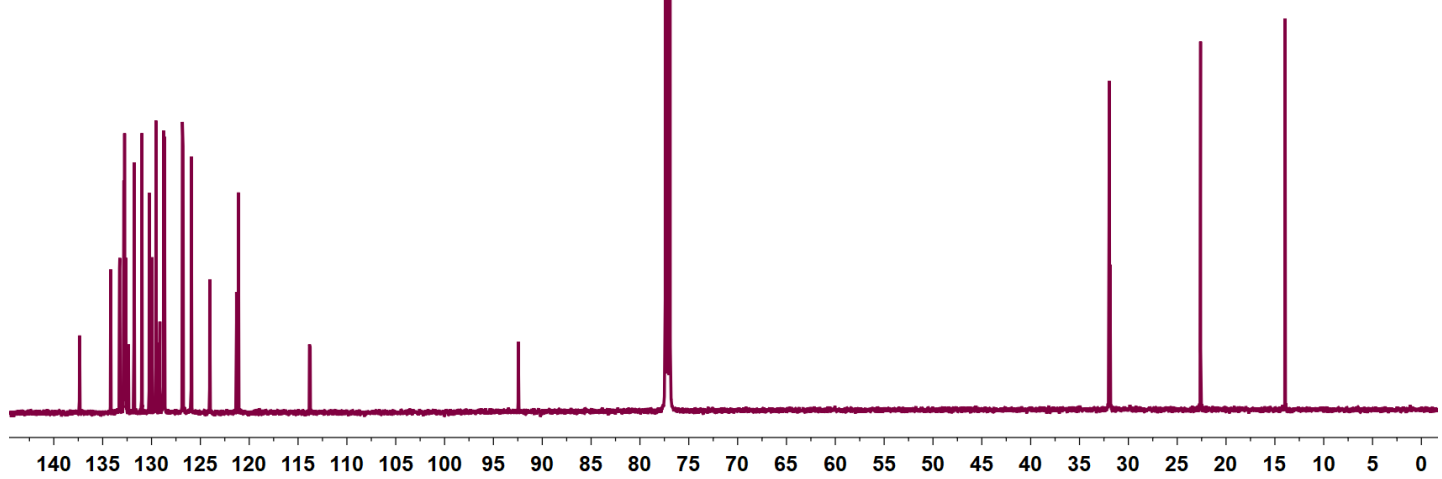

${ }^{13} \mathrm{C} \mathrm{NMR}$ spectrum of $\mathbf{6 a}$ in $\mathrm{CDCl}_{3}$. 
<smiles>CC(C)C1=Cc2c(c(I)c3ccc4cccc5ccc2c3c45)P(=O)(c2ccccc2)N1</smiles>
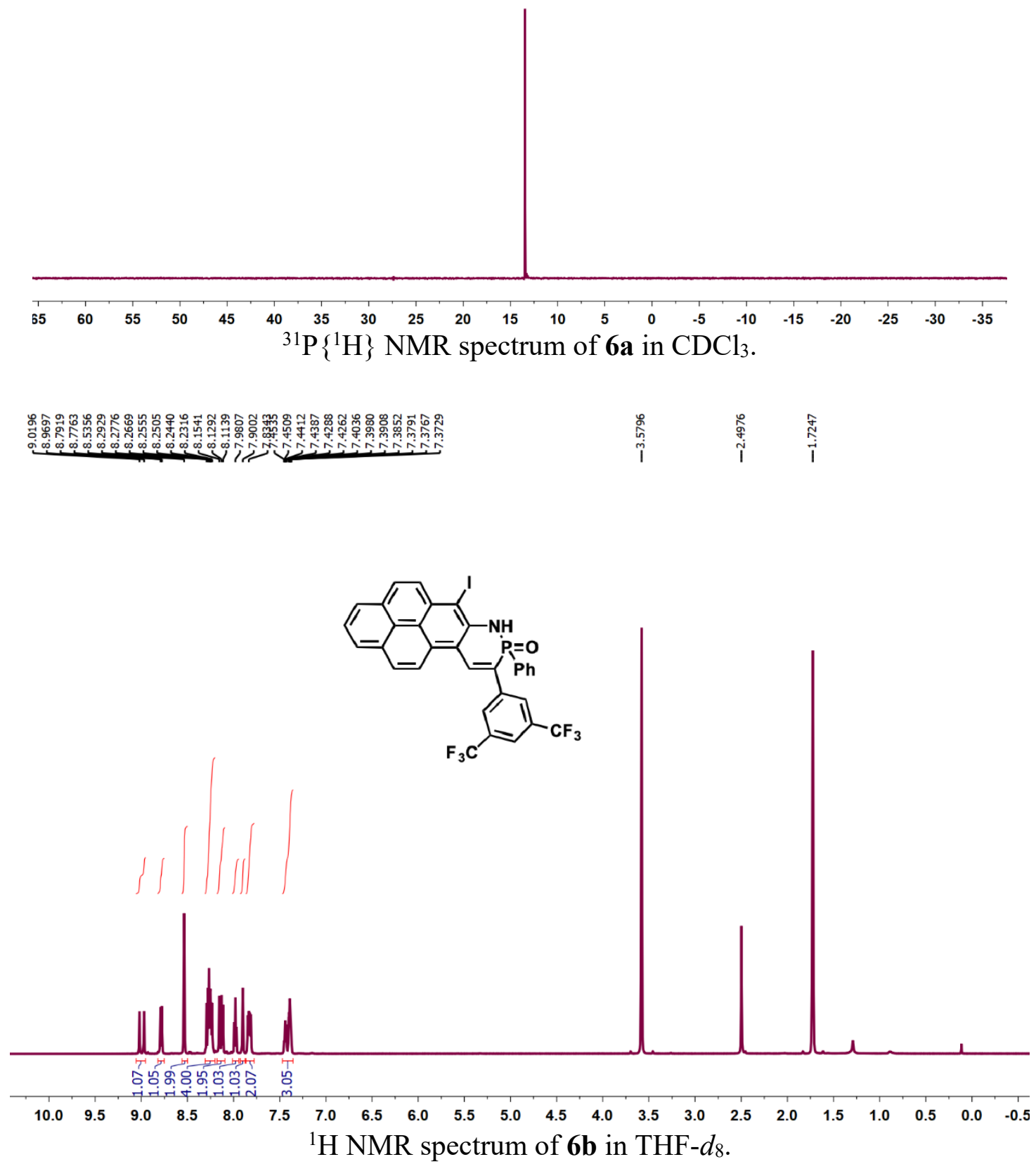


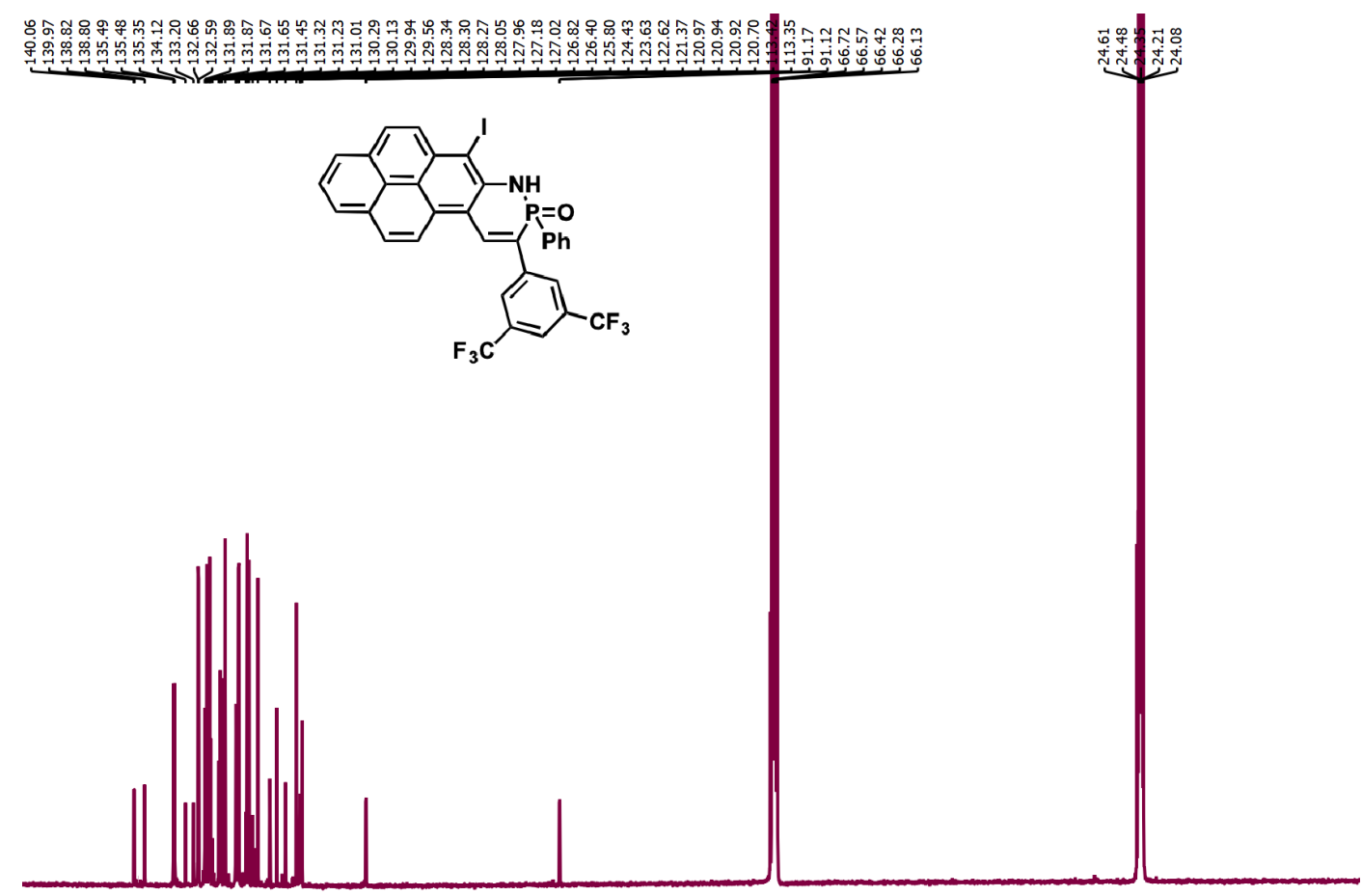

$\begin{array}{llllllllllllllllllllllllllllllll}150 & 145 & 140 & 135 & 130 & 125 & 120 & 115 & 110 & 105 & 100 & 95 & 90 & 85 & 80 & 75 & 70 & 65 & 60 & 55 & 50 & 45 & 40 & 35 & 30 & 25 & 20 & 15 & 10 & 5 & 0\end{array}$ ${ }^{13} \mathrm{C}$ NMR spectrum of $\mathbf{6 b}$ in THF- $d_{8}$.

iొ
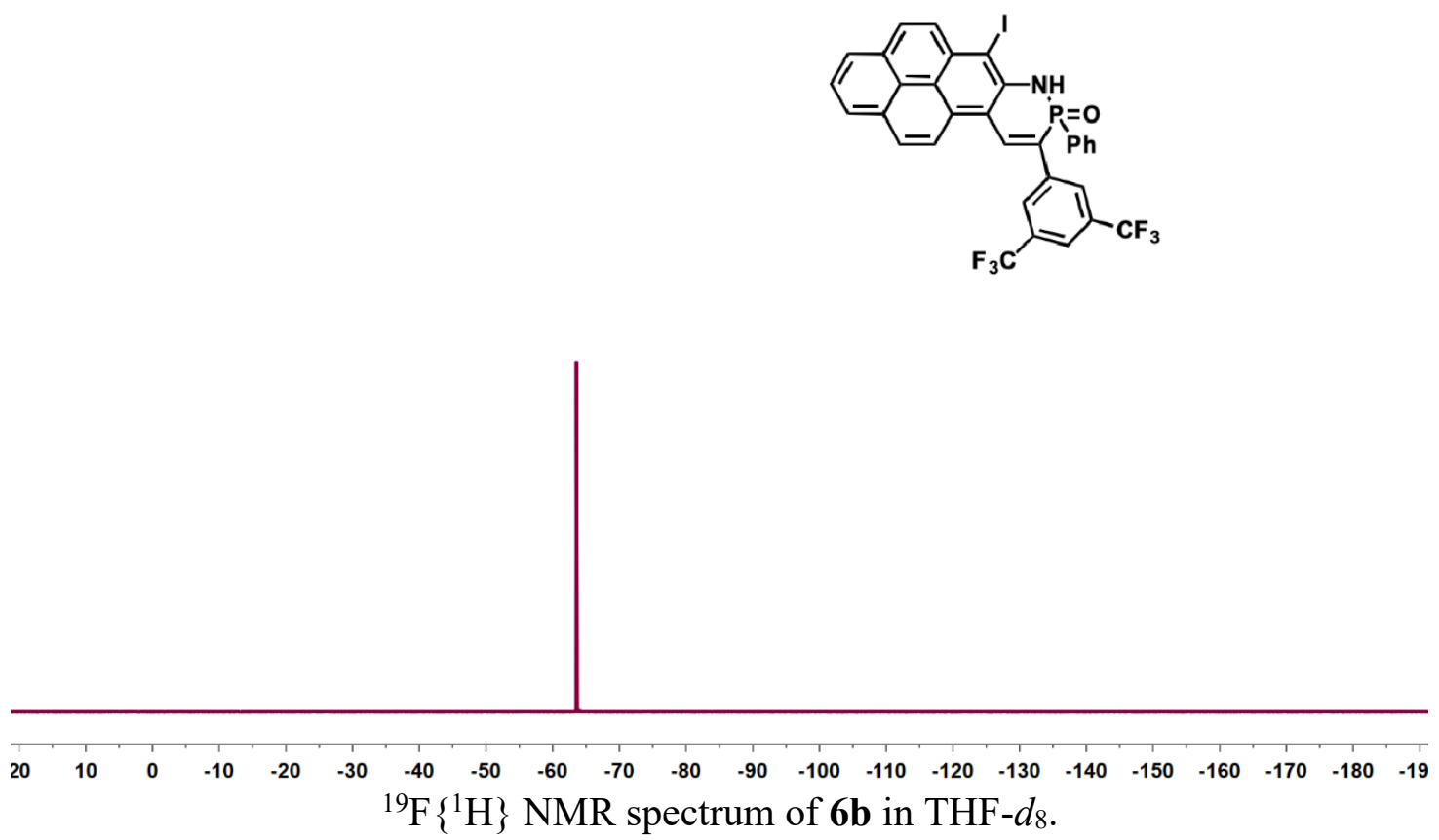


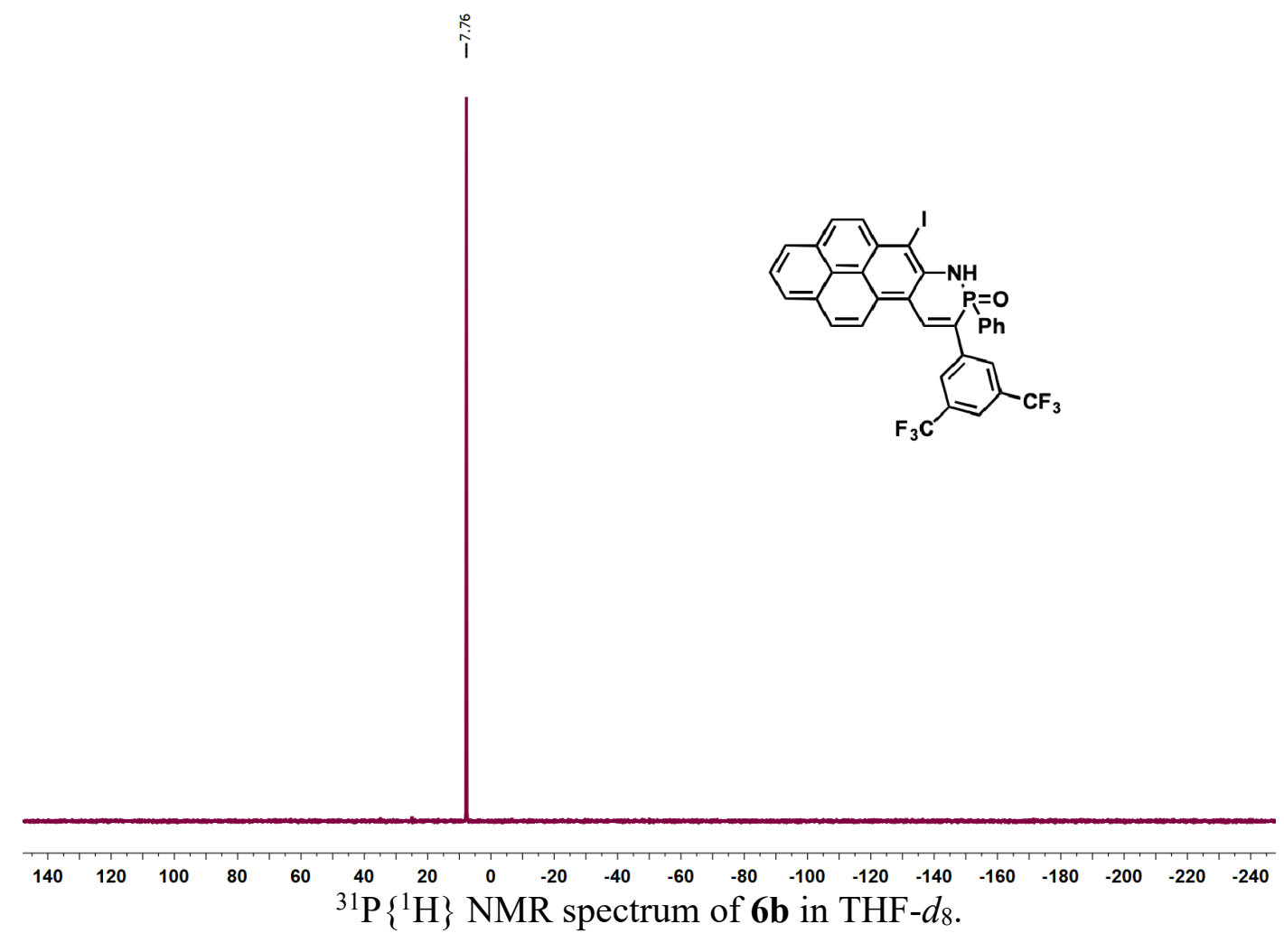

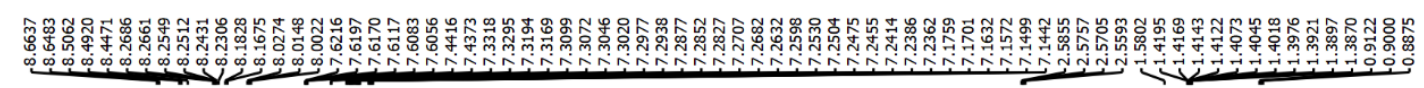

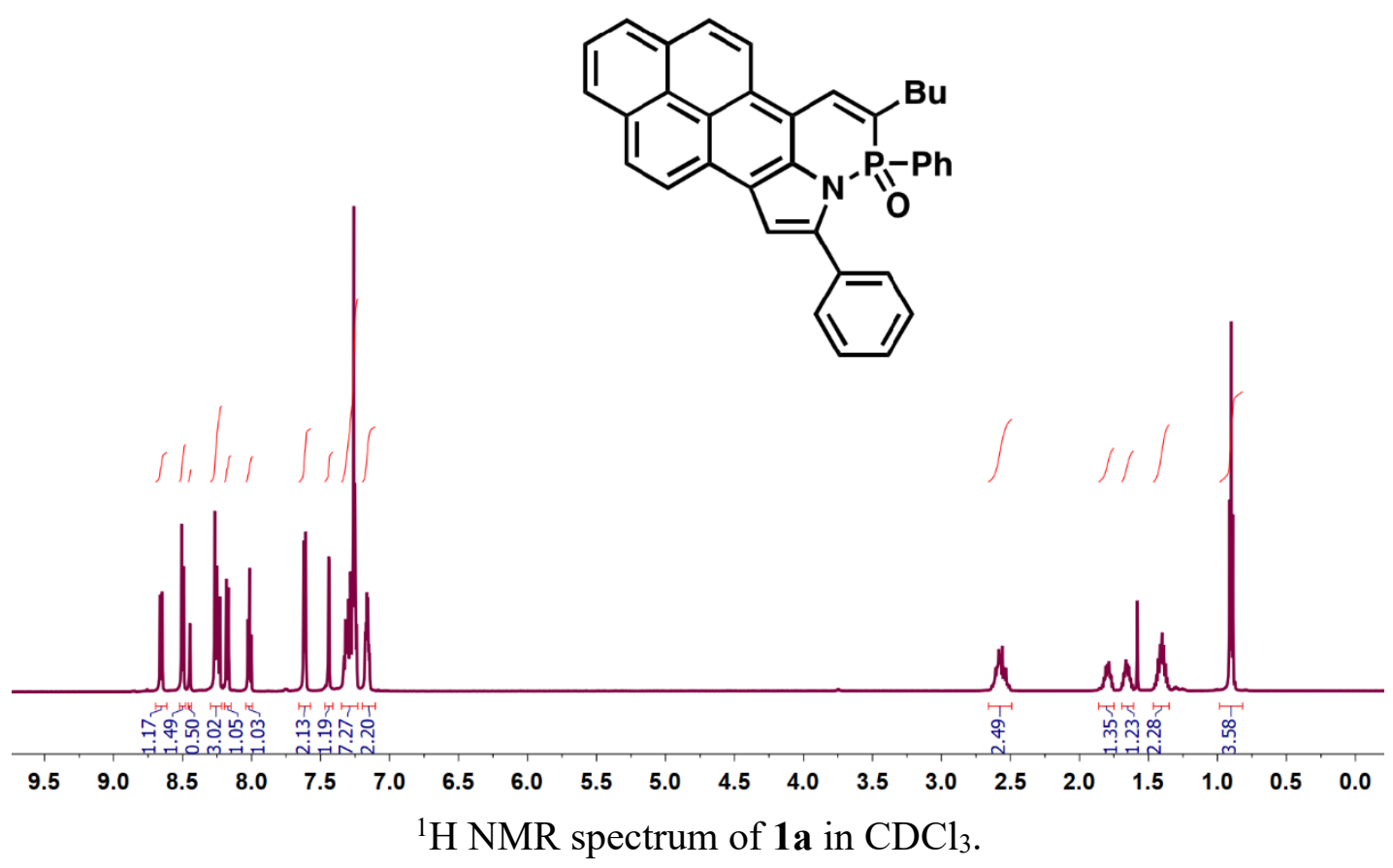



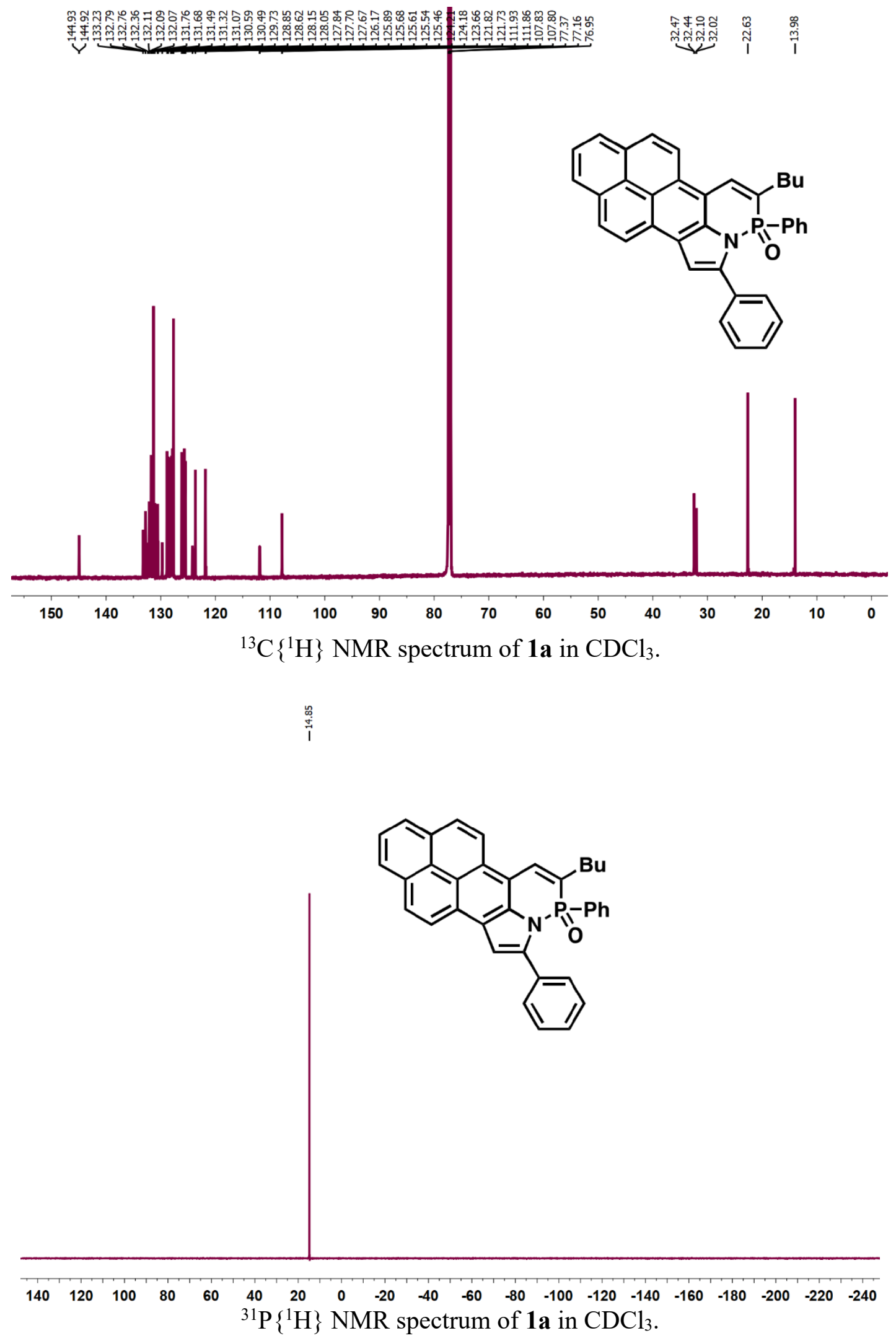

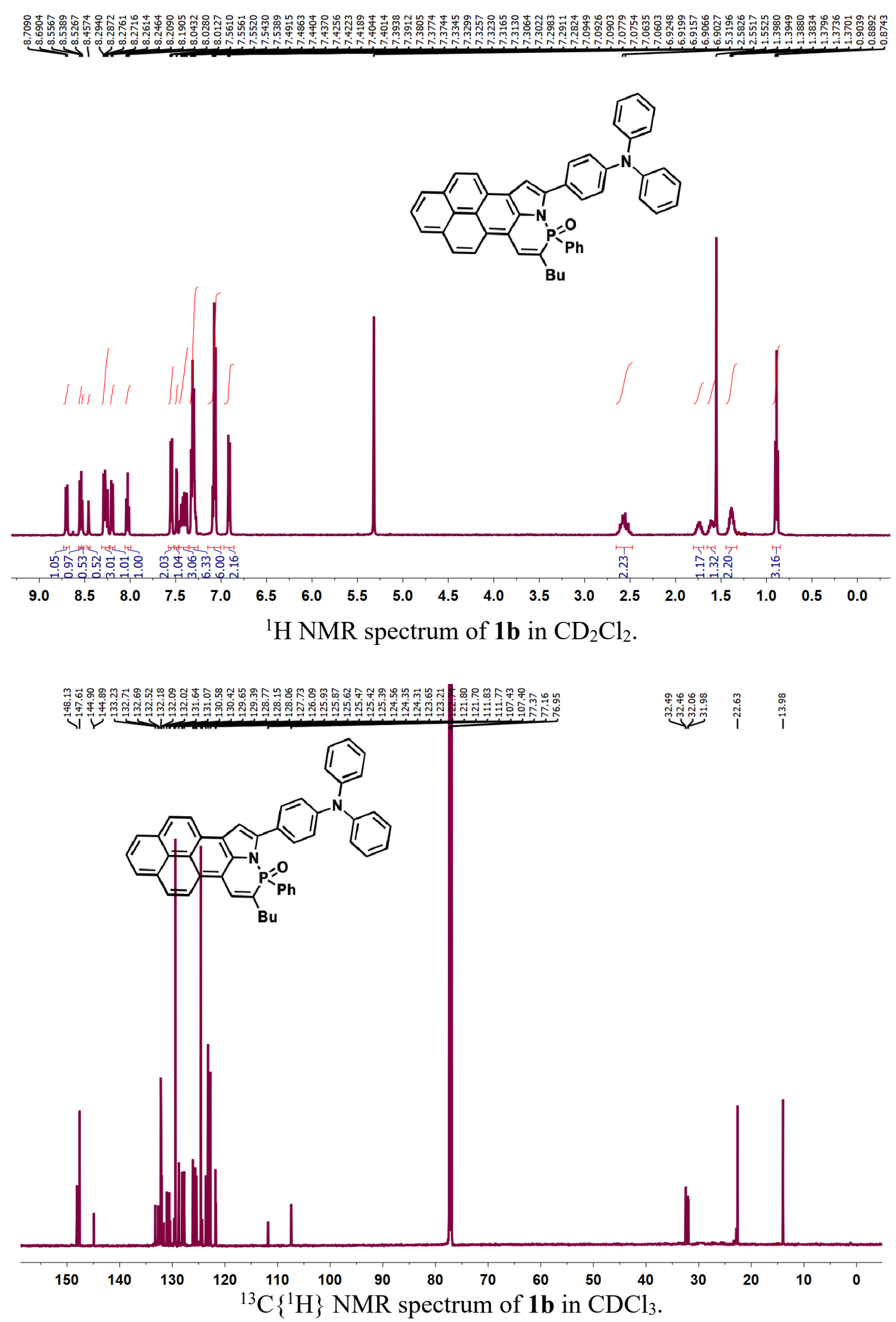

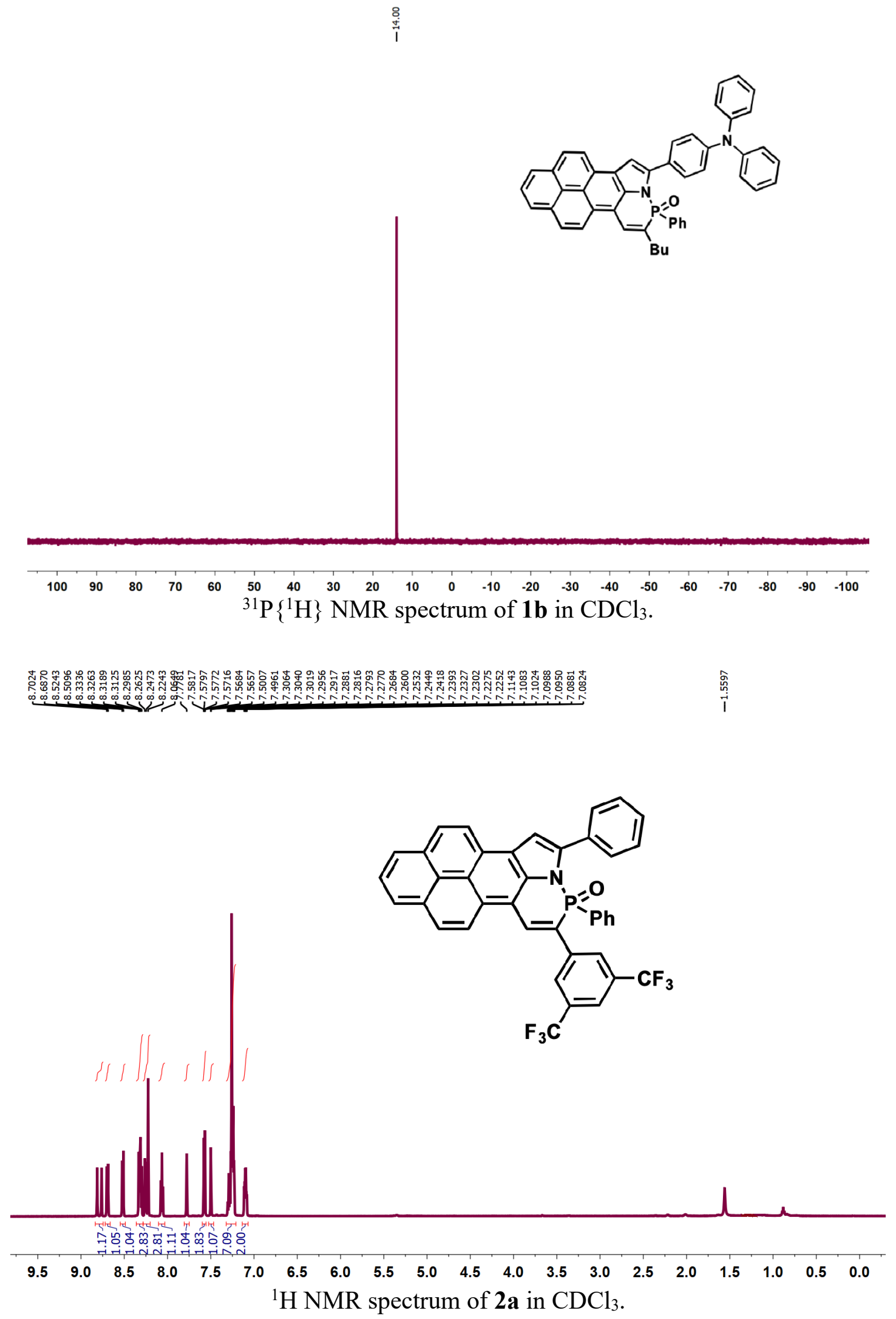

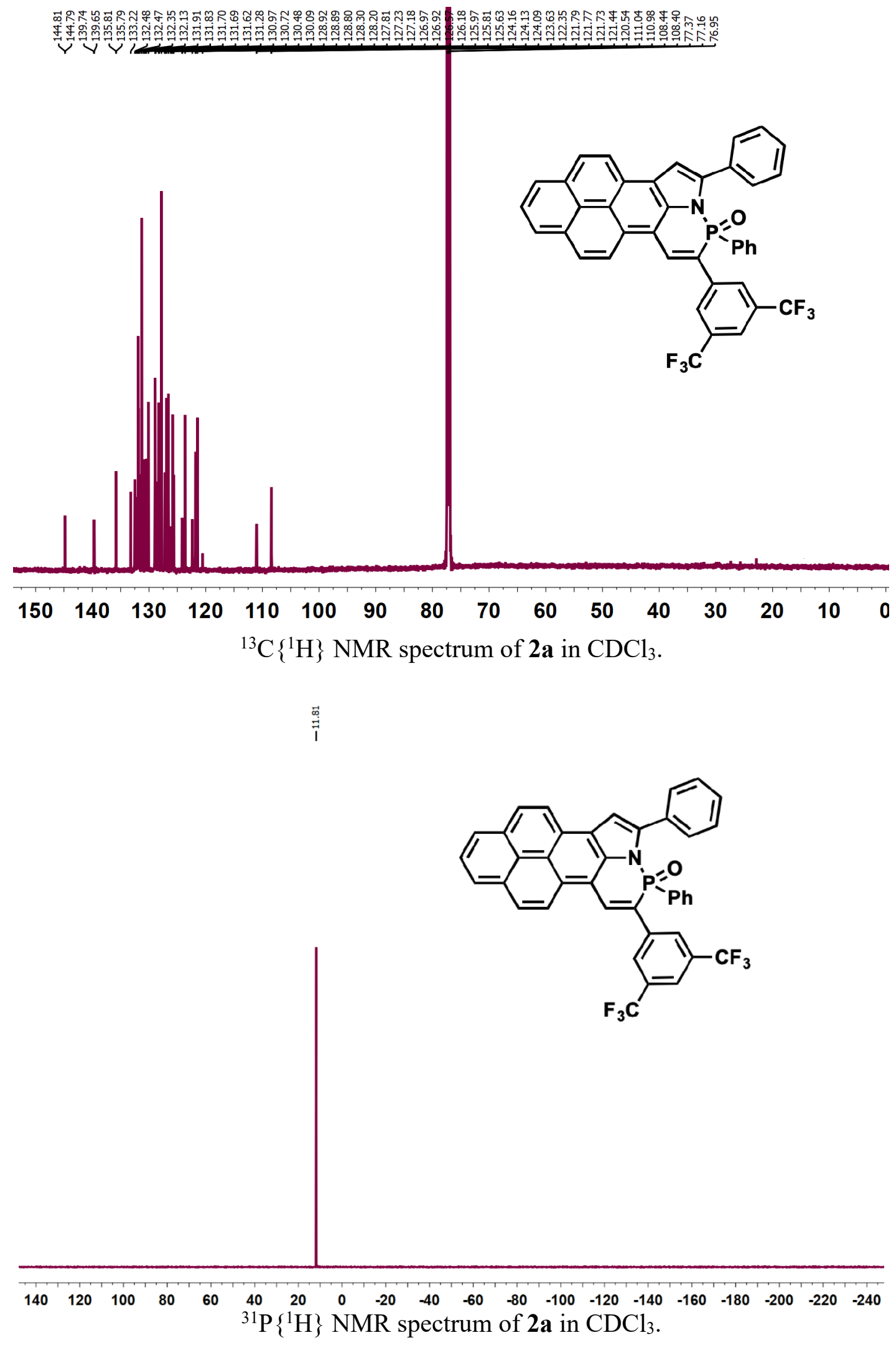


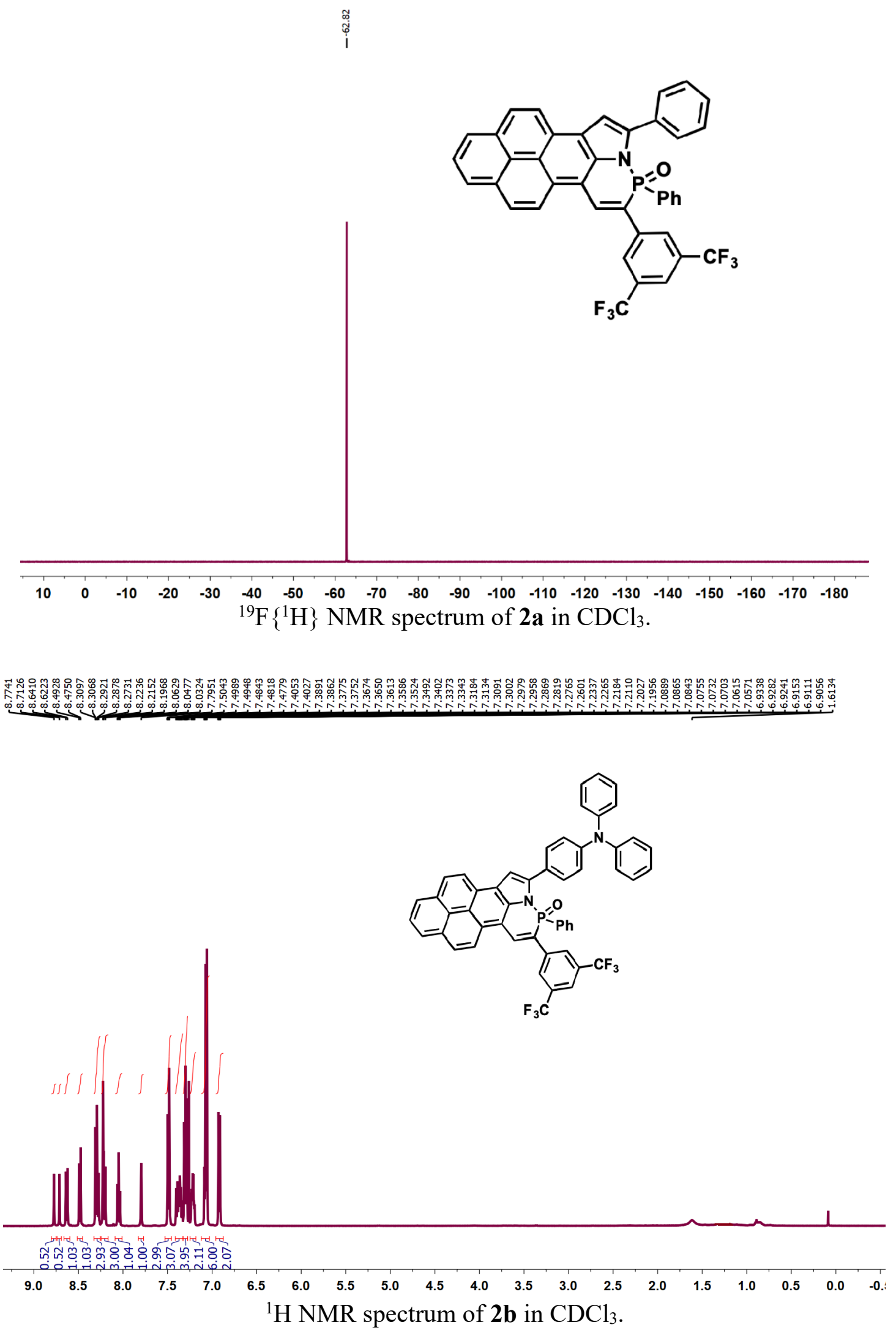



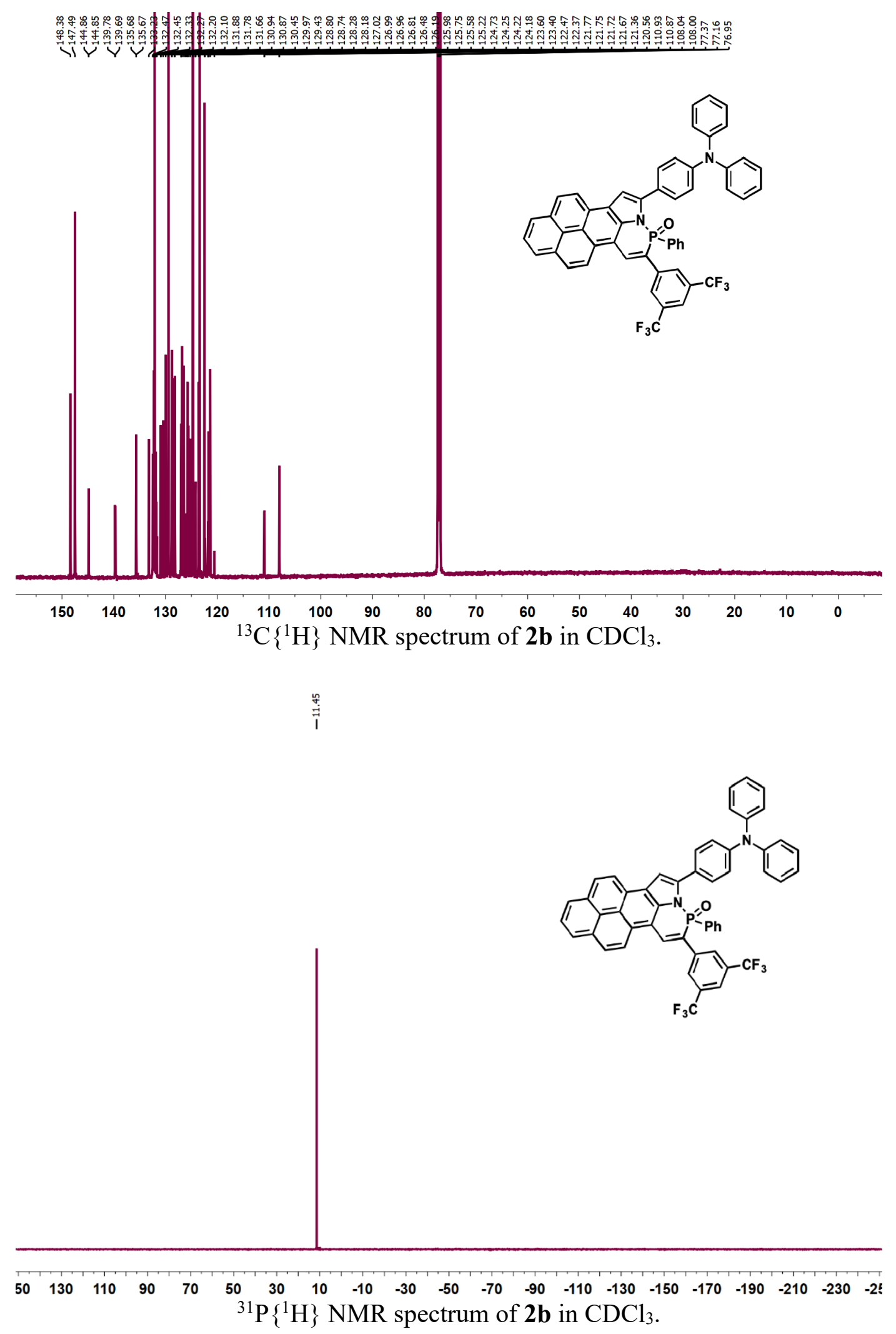

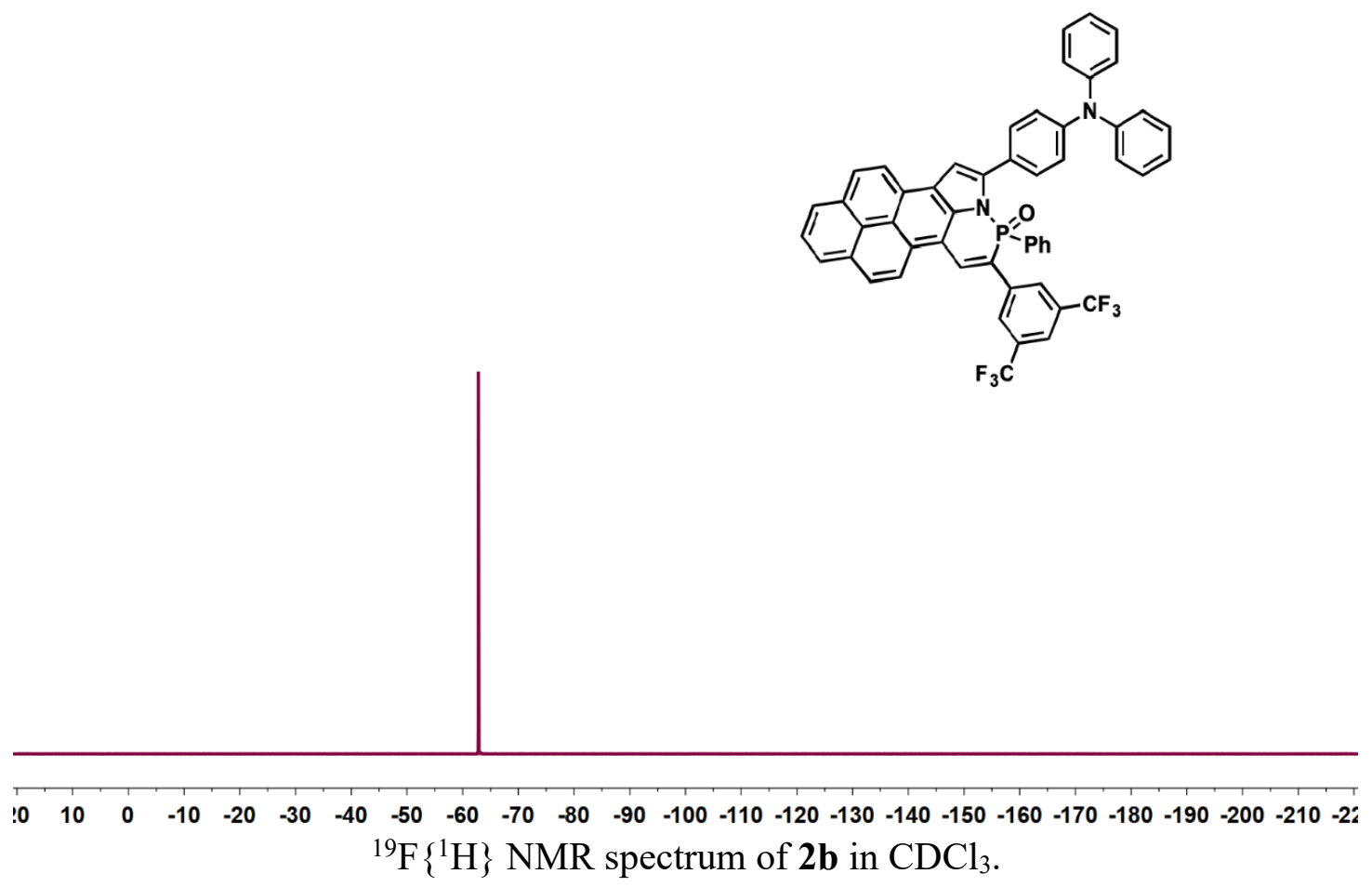

${ }^{19} \mathrm{~F}\left\{{ }^{1} \mathrm{H}\right\}$ NMR spectrum of $\mathbf{2 b}$ in $\mathrm{CDCl}_{3}$. 